\title{
Review
}

\section{A Global Review on Short Peptides: Frontiers and Perspectives ${ }^{\dagger}$}

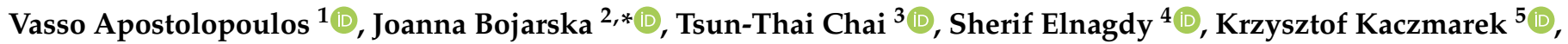 \\ John Matsoukas 1,6,7, Roger New ${ }^{8,9}$, Keykavous Parang ${ }^{10}$, Octavio Paredes Lopez ${ }^{11}$, Hamideh Parhiz ${ }^{12}$, \\ Conrad O. Perera ${ }^{13}$, Monica Pickholz ${ }^{14,15}$, Milan Remko ${ }^{16}$, Michele Saviano ${ }^{17}$, Mariusz Skwarczynski ${ }^{18}$, \\ Yefeng Tang ${ }^{19}$, Wojciech M. Wolf ${ }^{2, *}$, Taku Yoshiya ${ }^{20}{ }^{\circ}$, Janusz Zabrocki ${ }^{5}$, Piotr Zielenkiewicz ${ }^{21,22}{ }^{\mathbb{D}}$, \\ Maha AlKhazindar ${ }^{4}{ }^{\oplus}$, Vanessa Barriga ${ }^{1}$, Konstantinos Kelaidonis ${ }^{6}$, Elham Mousavinezhad Sarasia ${ }^{9}$ \\ and Istvan Toth $18,23,24$
}

\section{check for}

updates

Citation: Apostolopoulos, V.; Bojarska, J.; Chai, T.-T.; Elnagdy, S.; Kaczmarek, K.; Matsoukas, J.; New,

R.; Parang, K.; Lopez, O.P.; Parhiz, H.; et al. A Global Review on Short Peptides: Frontiers and Perspectives. Molecules 2021, 26, 430. https:// doi.org/10.3390/molecules26020430

\section{Academic Editor:}

Aleksandra Misicka-Kesik Received: 1 December 2020 Accepted: 9 January 2021 Published: 15 January 2021

Publisher's Note: MDPI stays neutral with regard to jurisdictional clai$\mathrm{ms}$ in published maps and institutional affiliations.

Copyright: (C) 2021 by the authors. Licensee MDPI, Basel, Switzerland. This article is an open access article distributed under the terms and conditions of the Creative Commons Attribution (CC BY) license (https:// creativecommons.org/licenses/by/ $4.0 /)$.
1 Institute for Health and Sport, Victoria University, Melbourne, VIC 3030, Australia; vasso.apostolopoulos@vu.edu.au (V.A.); imats1953@gmail.com (J.M.); vanessa.barriga@live.vu.edu.au (V.B.)

2 Institute of General and Ecological Chemistry, Faculty of Chemistry, Lodz University of Technology, Żeromskiego 116, 90-924 Lodz, Poland

3 Department of Chemical Science, Faculty of Science, Universiti Tunku Abdul Rahman, Kampar 31900, Malaysia; chaitt@utar.edu.my

4 Botany and Microbiology Department, Faculty of Science, Cairo University, Gamaa St., Giza 12613, Egypt; sh.elnagdy@gmail.com (S.E.); malkhazi@aucegypt.edu (M.A.)

5 Institute of Organic Chemistry, Faculty of Chemistry, Lodz University of Technology, Żeromskiego 116, 90-924 Lodz, Poland; krzysztof.kaczmarek@p.lodz.pl (K.K.); janusz.zabrocki@p.lodz.pl (J.Z.)

6 NewDrug, Patras Science Park, 26500 Patras, Greece; k.kelaidonis@gmail.com

7 Department of Physiology and Pharmacology, Cumming School of Medicine, University of Calgary, Calgary, AB T2N 4N1, Canada

8 Vaxcine (UK) Ltd., c/o London Bioscience Innovation Centre, London NW1 0NH, UK; r.new@vaxcine.co.uk

9 Faculty of Science \& Technology, Middlesex University, The Burroughs, London NW4 4BT, UK; EM1081@live.mdx.ac.uk

10 Center for Targeted Drug Delivery, Department of Biomedical and Pharmaceutical Sciences, Chapman University School of Pharmacy, Harry and Diane Rinker Health Science Campus, Irvine, CA 92618, USA; parang@chapman.edu

11 Centro de Investigación y de Estudios Avanzados del IPN, Departamento de Biotecnología y Bioquímica, Irapuato 36824, Guanajuato, Mexico; octavio.paredes@cinvestav.mx

12 Infectious Disease Division, Department of Medicine, Perelman School of Medicine, University of Pennsylvania, Philadelphia, PA 19104-6073, USA; hamideh.parhiz@pennmedicine.upenn.edu

13 School of Chemical Sciences, The University of Auckland, Private Bag 92019, Auckland 1142, New Zealand; c.perera@auckland.ac.nz

14 Departamento de Física, Facultad de Ciencias Exactas y Naturales, Universidad de Buenos Aires, Buenos Aires 1428, Argentina; monicapickholz2@gmail.com

15 Instituto de Física de Buenos Aires (IFIBA, UBA-CONICET), Argentina, Buenos Aires 1428, Argentina

16 Remedika, Luzna 9, 85104 Bratislava, Slovakia; milan.remko@gmail.com

17 Institute of Crystallography (CNR), Via Amendola 122/o, 70126 Bari, Italy; michele.saviano@cnr.it

18 School of Chemistry \& Molecular Biosciences, The University of Queensland, St Lucia, QLD 4072, Australia m.skwarczynski@uq.edu.au (M.S.); i.toth@uq.edu.au (I.T.)

19 Key Laboratory of Bioorganic Phosphorus Chemistry \& Chemical Biology (MOE), School of Pharma Ceutical Sciences, Tsinghua University, Beijing 100084, China; yefengtang@tsinghua.edu.cn

20 Peptide Institute, Inc., Osaka 567-0085, Japan; t.yoshiya@peptide.co.jp

21 Institute of Biochemistry and Biophysics, Polish Academy of Sciences, Pawinskiego 5a, 02-106 Warsaw, Poland; piotr@ibb.waw.pl

22 Department of Systems Biology, Institute of Experimental Plant Biology and Biotechnology, University of Warsaw, Miecznikowa 1, 02-096 Warsaw, Poland

23 Institute for Molecular Bioscience, The University of Queensland, St Lucia, QLD 4072, Australia

24 School of Pharmacy, The University of Queensland, Woolloongabba, QLD 4102, Australia

* Correspondence: joanna.bojarska@p.lodz.pl (J.B.); wojciech.wolf@p.lodz.pl (W.M.W.)

+ Dedicated to Professor Garland Marshall on the occasion of his 80th birthday.

Abstract: Peptides are fragments of proteins that carry out biological functions. They act as signaling entities via all domains of life and interfere with protein-protein interactions, which are indispensable in bio-processes. Short peptides include fundamental molecular information for a prelude to the symphony of life. They have aroused considerable interest due to their unique features and 
great promise in innovative bio-therapies. This work focusing on the current state-of-the-art short peptide-based therapeutical developments is the first global review written by researchers from all continents, as a celebration of 100 years of peptide therapeutics since the commencement of insulin therapy in the 1920s. Peptide "drugs" initially played only the role of hormone analogs to balance disorders. Nowadays, they achieve numerous biomedical tasks, can cross membranes, or reach intracellular targets. The role of peptides in bio-processes can hardly be mimicked by other chemical substances. The article is divided into independent sections, which are related to either the progress in short peptide-based theranostics or the problems posing challenge to bio-medicine. In particular, the SWOT analysis of short peptides, their relevance in therapies of diverse diseases, improvements in (bio)synthesis platforms, advanced nano-supramolecular technologies, aptamers, altered peptide ligands and in silico methodologies to overcome peptide limitations, modern smart bio-functional materials, vaccines, and drug/gene-targeted delivery systems are discussed.

Keywords: short peptides; constrained amino acids and peptide (bio)mimetics; drug design and drug/gene delivery; vaccines; aptamers; cell-penetrating peptides; synthesis; SARS-COV-2; cancer; bilayer interactions; altered peptide ligands; ant/super/agonists; diketopiperazine; cosmeceuticals

1. Introduction

2. Brief History

3. Short Peptides: Definition

4. Frontiers and Prospects of Short Peptides

4.1. Advantages vs. Disadvantages: SWOT Analysis

4.2. To Overcome Shortcomings of Peptides: Mission (Im)possible?

4.2.1. Constrained Amino-Acids as a Molecular "Meccano"

4.2.2. Cyclic Peptides and Mimetics

4.2.3. Ultra-Short Peptides: Less Is More

4.2.4. Nanoengineering \& a Supramolecular Approach

5. Synthesis

5.1. Advances in the Synthesis of Short Peptides and Modified Amino Acids

5.2. Short Difficult Peptide Synthesis

6. In Silico Studies

6.1. Geometry Optimization, Conformational Analysis

6.2. Modelling of Short Peptides

6.3. Peptide Interactions with Lipid Bilayers using Molecular Dynamics Simulations 7. Peptide-Based Therapies

7.1. Monocyclic, Bicyclic and Tricyclic Cell-Penetrating Peptides as Molecular Transporters 7.2. Short Peptides in Gene Delivery

7.3. Taking Peptide Aptamers to a New Level

7.4. Peptide-Based Vaccines

7.5. The Role of Short Peptides in Neurodegenerative Therapy

7.6. Immune Modulation Using Altered Peptide Ligands in Autoimmune Diseases

7.7. Relevance of Short Peptides in Stem Cell Research

7.8. Short Peptide-Based Anti-Viral Agents against SARS-CoV-2

7.9. Antimicrobial Lactoferrin-Based Peptides as Anti-COVID-19

7.10. Peptides from Digestion of Proteins

7.11. Nutraceuticals

7.12. Marine Peptides

7.13. Peptide-Based Cosmeceuticals

\section{Introduction}

Recently, short peptides have attracted increasing attention in biology, chemistry, and medicine due to their specific features. They are appreciated as novel and more efficient therapeutical agents with reduced side effects. Their structural diversity combined 
with the conformational flexibility is used to control interactions with particular receptor sites. Peptides display high selectivity due to specific interactions with their targets. Moreover, the number of short peptides involved in important biological processes is steadily growing by far exceeding that resulting from the traditional mimetic approach. Unfortunately, peptides also have profound medical limitations, namely the development of oral peptide-based therapeuticals that modulate cellular processes via high affinity binding is like a search for the Holy Grail [1].

This critical review is written by a broad, multidisciplinary group of leading scientists, experts in the field from academia and pharmacy from all continents of the world providing a priceless global point of view on short peptides towards biomedical innovations. It is compiled as a holistic story from very simple bio-molecules to next-generation advanced theranostics in diverse, multidirectional scenarios. More specifically, the advantages vs. disadvantages of short peptides, their relevance in therapies of a wide range of diseases, improvements in (bio)synthesis platforms, advanced nano-supramolecular technologies, aptamers, altered peptide ligands and in silico methodologies to overcome peptide limitations, modern smart bio-functional materials, vaccines, and drug/genetargeted delivery systems are considered. It gains unequaled insight into the world of functional biologically active peptides either accessible from nature's repertoire or synthetic species. Short peptides, as fragments of proteins, have become intriguing agents of almost unlimited possibilities, which are awaiting further exploitation in the near future. We profoundly believe that these simple bio-molecules will open up whole new vistas, offering promising solutions in shaping the future novel bio-medicine.

\section{Brief History}

In 1902, two distinguished German chemists, Hermann Emil Fischer and Franz Hofmeister, proposed that proteins are constituted by amino acids linked by bonds between the amino group of the proceeding amino acid and the carboxyl group of the following residue [2]. However, proteins were initially characterized by the Dutch chemist Gerardus Johannes Mulder, but their name was coined out by the Swedish chemist Jöns Jacob Berzelius, in 1838 [3,4]. The term "protein" is derived from the "proteios" ("primary") i.e., representing the first position in living organisms [4-6]. Nevertheless, proteins do not exist without peptides. A name "peptide" comes from "peptós" (in Greek "digested, digestible") and reflects the fact that peptides are generated by the proteolytic cleavage reaction. The first peptides and amino acids were discovered at the beginning of 19th century $[7,8]$. The first amino acid, asparagine, was isolated from asparagus by French chemists Louis-Nicolas Vauquelin and Pierre Jean Robiquet in 1806 [9,10]. Their chemical category was recognized by the French Charles Adolphe Wurtz, in 1865, but the expression "amino acid" was used for the first time in 1894, in German as Aminosäure [11,12]. Interestingly, the first peptide, benzoylglycylglycine, was synthesized by the German chemist Theodor Curtius, in 1881 [13]. However, a more efficient synthesis was described by Fischer and the French chemist Ernest Fourneau in 1901 [14,15]. In consequence, Fisher is known as the "father" of peptide chemistry [16].

Peptides exist in all terrestrial living organisms and are indivisibly related to the origin of life [17]. Cooperative interactions among peptides and other molecules (amino acids, proteins, nucleic acids, lipids) were the driving forces at all stages of chemical evolution [18]. Nowadays, a chemical peptide synthetic biology approach facilitates theories on the creation of life, in particular in the eyes of scientists who believe that historically chemistry proceeds biology [19-21].

\section{Short Peptides: Definition}

In general, a peptide consists of at least two amino acids. An oligopeptide is a short chain of amino acids ("a few"). A polypeptide is a long chain of amino acids ("many"). Protein contains at least one polypeptide chain folded into correct shapes. There is no strict boundary between a peptide and a protein or an oligopeptide and a polypeptide other than 
the "size". As stated in the International Union of Pure and Applied Chemistry (IUPAC), oligopeptides consist of fewer than about 10-20 amino acids, while polypeptides have more than 20 residues [22]. According to the biological dictionary, oligopeptides comprise about 2-40 amino acids, while the medical definition indicates a fragment of protein consisting of fewer than 25 amino acids. On the other hand, proteins, according to IUPAC can be polypeptides consisting of more than about 50 mers, but there are great differences regarding the term protein. In the Britannica encyclopedia, we can read: "peptide chains longer than a few dozen amino acids are called proteins" [23]. Typical proteins contain over 100 amino acids $[5,24]$. The smallest natural mini-protein is crambin, consisting of 46 amino acids [25], while the largest protein is titin with 38,138 amino acid residues [26]. Hence, the determination of "short peptide" is problematic. It depends on the reference point. The strict definition has not been given so far. Short peptides have features of oligomers rather than polymers [5], but there is no clear consensus among scientists. In the literature, we can find contradictory information, with fewer than 30 [27-29] or 50 [30-33], up to 100 residues [34]. On the other hand, ultra-short peptides were precisely defined as peptides consisting of up to seven amino acids [35-38].

In view of the above, we can conclude that oligopeptides are always only peptides, while polypeptides can be proteins as well. Consequently, short peptides should not include more than 45 amino acids.

\section{Frontiers and Prospects of Short Peptides}

\subsection{Advantages vs. Disadvantages: SWOT Analysis}

Peptides as a unique class of bio-molecules have filled the therapeutic niche due to their specific biochemical and therapeutic features. They explore the "middle space" between small chemical molecules and biologics because of their molecular weight. They have the intermediate nature extending "beyond size", combining the advantages of both small molecular drugs (e.g., better permeability) and therapeutic proteins (selectivity, target potency) and exluding their disadvantages, such as adverse side effects, drug-drug interactions, and membrane impermeability, respectively.

Short peptides have evolved as a very promising scaffold for diverse applications either in diagnosis or therapies. The current status of their strengths, weaknesses, opportunities and threats (SWOT analysis) [39] is briefly discussed (Table 1).

Table 1. SWOT analysis of short peptides.

\begin{tabular}{ll}
\hline \multicolumn{1}{c}{ Strengths } & \multicolumn{1}{c}{ Weaknesses } \\
\hline $\begin{array}{l}\text { essential bio-molecules with a broad range of activities \& } \\
\text { functionalities in vivo }\end{array}$ & $\begin{array}{l}\text { instability in vivo (easy degradation in plasma, } \\
\text { protease sensitivity) }\end{array}$ \\
\hline bio-chemical diversity, easy availability & short half-life \\
\hline structural simplicity & low (oral) bioavailability \\
\hline easy design \& cost-effective synthesis with high purity & difficult membrane permeability in the case of greater peptides * \\
\hline easy modification, scaling up & low binding affinity * \\
\hline $\begin{array}{l}\text { mechanical stability } \\
\text { high: modularity, flexibility *, selectivity, target specificity, } \\
\text { affinity *, absorbability, potency, tolerability, efficacy, safety, } \\
\text { biocompatibility, biodegradibility }\end{array}$ & \\
\hline \begin{tabular}{l} 
low toxicity, antigenicity, immunogenicity \\
\hline easy recognition by bio-systems
\end{tabular} & \\
\hline $\begin{array}{l}\text { ability to penetrate the cell membranes (but only very short } \\
\text { peptides) }\end{array}$ & \\
administration
\end{tabular}


Table 1. Cont.

\begin{tabular}{ll}
\hline \multicolumn{1}{c}{ Strengths } & Weaknesses \\
\hline versatility as both targeting moieties and therapeutic agents & \\
\hline specific interactions with various bio-systems \\
\hline $\begin{array}{l}\text { predictable metabolism: degradation products are amino acids } \\
\text { (non-toxic, natural entities used as nutrients or cellular } \\
\text { building blocks) }\end{array}$ \\
$\begin{array}{l}\text { lack or fewer secondary off-targets (side) effects (peptides do } \\
\text { not accumulate in kidney or liver) }\end{array}$ \\
\begin{tabular}{l} 
low unspecific binding to the structures other than the desired \\
target, minimisation of drug-drug interactions, less \\
accumulation in tissues (low risk of complications due to \\
\hline Optermediate metabolites)
\end{tabular} \\
\hline
\end{tabular}

development of peptide-based delivery systems:

- cell-penetrating peptides

- nano-cyclic peptide-based micceles, vesicles as gene or drug carriers

- conjugations with non-peptidic motifs

supramolecular peptide-based biofunctional materials

oncogenicity of endogenous \& synthetic peptides

supramolecular peptide-based biofunctional materials

formulations development (e.g., subcutaneous

injections)various forms of using (drugs, vaccines,

hormones, radioisotopes)

development of the peptide-based safe \& effective vaccines

diveristy of well-ordered, robust, long-lived

self-assembled nanostructures

vital tool for neurodegenerative diseases studies \& various

applications in anticancer therapy

peptoids or peptidomimetics

* Bivalent property which may be either strength or weakness depending on particular species.

First of all, short peptides have numerous advantages in comparison with their larger analogues. In particular, cost-effective synthesis both on a small- and large-scale, wide chemical diversity, easy modification, high bio-activity, absorbability, accessibility, tunable functionalization, high selectivity and specificity, biodegradability and biocompatibility, high safety, low toxicity (due to their safe metabolites-amino acids, the limited possibility for accumulation in the body), or low immunogenicity should be emphasised [40]. Peptides have diverse bio-functionalities of their components (amino acids) and good biomolecular recognition [34,41]. As a consequence, they have high binding affinity for a wide range of specific targets.

On the other hand, short peptides have limitations, such as high conformational flexibility (can result inter alia in the lack of receptor selectivity) or problems in permeability of greater peptides via physicological barriers (due to the strong interactions of peptide backbone with water molecules) [42]. Moreover, there are other important factors, e.g., short half-life in vivo (due to the susceptibility to rapid digestion by protolytic enzymes in the gastrointestinal tract and serum, proteases/peptidases) and fast clearance from the circulation (first-pass metabolism) by the liver and kidneys (lasting from minutes to hours after administration). In spite of approvement of over 60 peptide drugs, nearly none can be orally administrated [43]. Market placement of effective peptides as oral medications is still the "Holy Grail". Furthermore, the risk of immunogenic effects is the main threat of peptide therapies [42]. 


\subsection{To Overcome Shortcomings of Peptides: Mission (Im)possible?}

There are different approaches and strategies to overcome peptide limitations and enhance their bio-clinical applications [44]. First and foremost, structural modifications can lead to the improvement of physicochemical properties. Simple modifications result in greater general stability. It can be additionally improved by "double-bridged peptides" when peptides are cyclized via two chemical bridges. It reduces peptide backbone flexibility and in consequence, leads to limited availability for enzymes. Furthermore, variations in the sequence lenght and side chains, peptide backbone modification, C-terminal amidation, N-terminal acetylation, addition of stabilizing (sugars, salts, heparine) and chelating agents, e.g., ethylenediaminetetraacetic acid (EDTA), conjugations with large biocompatible polymers, such as polyethylene glycol (PEG), or fatty acids can be applied. In this way, we can stabilize peptides in their bioactive conformation, increase efficiency, hydrodynamic volume, and reduce renal clearanced and show greater membrane permeability and target selectivity $[33,41-45]$. Furthermore, the conjugation to cell-penetrating peptides (or organelle-targeting sequences) increases cellular membrane crossing and allows accessing intracellular targets by peptide-drugs or acts as gene delivery vectors revealing great potential for clinical use as theranostics leading to better drug bioavailability and therapeutic efficiency [46,47]. The conjugations of short peptides with non-peptidic motifs enhance bioactivities: A promising strategy for the discovery of new drugs (improve peptide delivery and cellular uptake) [48]. Synthetic short peptides as accurate copies of protein parts are ideal tools for imitation of protein sites [47]. Peptoids, which are based on native peptides, can lead to the improved pharmacokinetic profile $[49,50]$. Novel methods such as phage display can be used to develop short peptides, which can survive proteolytic degradation in the gastrointestinal tract and can be used as therapeutical agents with high affinity in inhibition of the coagulation Factor XIa or as antagonists for the interleukin-23 receptor in the chronic inflammatory Crohn's disease, ulcerative colitis [51]. They may be a milestone towards engineering oral peptide drugs in the treatment of diseases affecting billions of people worldwide [52,53].

\subsubsection{Constrained Amino-Acids as a Molecular "Meccano"}

Intensive efforts have been made to develop short peptides or peptidomimetics that display more favourable pharmacological properties than their prototypes [54]. Most of the research carried out in the field concern the preparation of analogues with different chemical structure and possibly modified conformational preferences, responsible for inducing changes in the biological activity. Structural changes can be obtained in a peptide by selectively substituting along the sequence specific residues with other residues or by substituting certain residues of the sequence with non-coded $\alpha$-amino acid residues. Appropriate constrained non-coded $\alpha$-amino acid residues are of particular interest as "building blocks" for the preparation of analogs, since their inclusion in a peptide sequence could maintain the pharmacological properties of the native peptide and possibly enhance resistance to biodegradation with improved bioavailability and pharmacokinetics. Several solid-state studies have been carried out to define the conformational preferences in solution and in the solid-state of specific classes of non-coded $\alpha, \alpha$-amino acids, for example, the symmetrical and unsymmetrical $\alpha, \alpha$-disubstituted glycines $(\alpha, \alpha$-dialkylated amino acid residues) (Figure 1) [55-66]. The structural preferences of peptides containing non coded amino acid residue are unique with significant constraints of their conformational freedom. This point is particularly important for the use of these residues and their analogues as scaffolding units in the de novo design of protein and enzyme mimetics and, also, as templates for molecular and chiral recognition studies. More in general with this knowledge we are able to rationally design new peptides relevant to pharmacology and medicinal chemistry, which might mimic biological processes by enhancing or in general modulating their effects. The peptide pharmaceutical targets of these studies have been among others hormones, enzymes, transport systems, antibiotics, sweeteners, etc. [67-72]. Another important application of constrained amino acid is in the peptide self-assembly. 
This process governs the organization of proteins, controlling their folding kinetics and preserving their structural stability and bioactivity. In this connection, model oligopeptides containing $\alpha, \alpha$-disubstituted glycines can give important insights into the molecular mechanisms and elementary forces driving the formation of supramolecular structures with potential application in tissue engineering $[73,74]$.

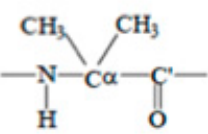

Aib<smiles>CCC(C)(C)C(C)=O</smiles>

Iva

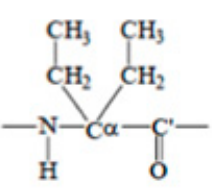

Deg

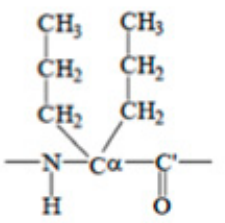

Dpg<smiles>CCC(=O)C(C)NC(C)CC</smiles>

$\mathrm{Ac}_{\mathrm{n}} \mathbf{c}$<smiles>CCC(C)C(C)C=O</smiles>

( $\alpha$ Me)Leu<smiles>CCCC(C)(NC)C(C)=O</smiles>

$(\alpha M e)$ Nva<smiles>CNC(C)(Cc1ccccc1)C(C)=O</smiles>

( $\alpha$ Me)Phe

Figure 1. Schematic representation of some symmetrical $C^{\alpha, \alpha}$-dialkylated glycine and chiral $\alpha$-methylated residues.

\subsubsection{Cyclic Peptides and Mimetics}

Cyclic peptides constitute a class of compounds that were used in the treatment of certain diseases. Examples of such well known cyclic peptides are insulin, penicillin, cyclosporin, and gramicidin S. Cyclic peptides, compared to linear peptides, have been proved to show greater potential as therapeutic agents due to their increased chemical and enzymatic stability, receptor selectively and improved pharmacodynamic properties. In our peptide research, cyclization of peptides is a key step towards non peptide mimetics which is the final target [75]. Our research group was the first, worldwide, to synthesize cyclic analogues of important peptides such as angiotensin II (implicated in hypertension), myelin epitope peptides (implicated in multiple sclerosis), gonadotropin releasing hormone (implicated in infertility and cancer), and thrombin receptor activating peptides (implicated in angiogenesis and cancer) [76-84]. Another way of transforming peptides to peptide mimetics is by conjugating peptides to sugars like mannan, used as antigen carriers in cancer and in multiple sclerosis research [85]. The octapeptide hormone angiotensin II is one of the best studied peptides with the aim to design and synthesize non peptide mimetics for oral administration $[75,86,87]$. To achieve this target, cyclizations at different positions within the peptide molecule was a useful strategy to define the active conformation [78-81]. These studies on angiotensin II led to the discovery of sarmesin, a type II angiotensin II antagonist and the breakthrough non-peptide mimetic losartan, the first in a series of sartans marketed as a new generation of anti-hypertensive drugs in 1990 s $[78,79,88,89]$. These studies led also to the ring cluster conformation of angiotensin II and the charge relay system hypothesis confirmed by fluorescence studies [90]. Synthesis of cyclic peptides, in our studies, was pursued as an intermediate step towards constructing non peptide mimetics which as drugs have the merit to be administered orally. The limited stability of peptides, due to hydrolysis of amide bonds, severely restricts their medical and industrial application. Therefore, the engineering of stable peptide moieties, which are the cyclic counterparts and non-peptide mimetics is of outmost importance. Furthermore, cyclizations were a way to define and lock the active conformation of the peptide. Structureactivity studies have shown the importance of the three aromatic amino acids Tyr, His, 
Phe, and the C-terminal carboxylate for activity. In order for cyclic analogues to retain the activity of the linear peptide, cyclization should occur at residue positions that are the least important for activity with retention of the bioactive conformation [78-81]. The conformation of peptides is deduced from modern Nuclear Magnetic Resonance techniques, such as two-dimensional (2D) NMR ROESY, NOESY, COSY, and TOCSY in lipophilic environments. Based on losartan, sarmesin, and our ring cluster and charge relay system conformation, we designed and synethsized angiotensin II receptor blockers by rotation of the alkyl chain on the imidazole ring. This rotation resulted in losartan V8 and BV6 derivatives of similar activity with losartan $[91,92]$. The perspectives in the use of angiotensin receptor blockers (ARB) are huge. ARB and angiotensin-converting enzyme (ACE)1 inhibitors were recently found to protect hypertensive patients infected from Severe Acute Respiratory Syndrome Coronavirus (SARS-Cov-2) [93]. The renin-angiotensin system (RAS) inhibitors reduce the toxic angiotensin II and increase antagonist heptapeptides alamandine and aspamandine, which counterbalance angiotensin II and maintain homeostasis and vasodilation [94] (Figure 2).
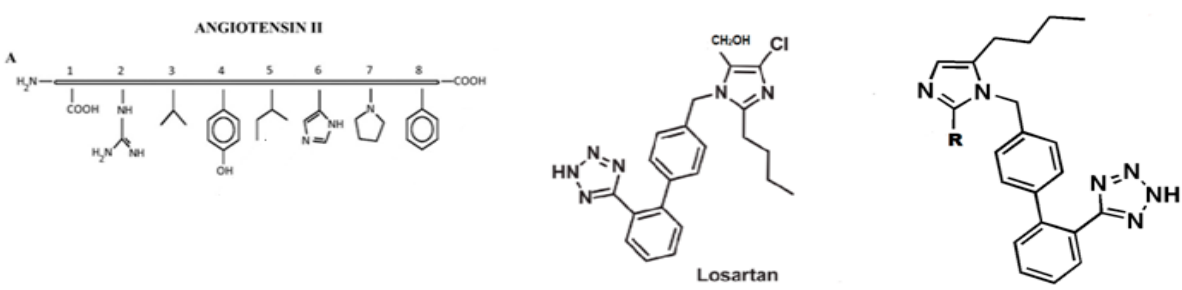

Figure 2. Angiotensin II (Asp-Arg-Val-Tyr-Ile-His-Pro-Phe), Losartan, V8 Losartan analogues $\left(\mathrm{R}=\mathrm{CH}_{2} \mathrm{OH}, \mathrm{COOH}\right)$. The angiotensin II scheme depicts the pharmacophoric groups of the eight amino acids of angiotensin II.

\subsubsection{Ultra-Short Peptides: Less Is More}

Very short peptides have outstanding attributes, such as much easier and economic synthesis, higher mechanical stability, good tissue penetration, and less immunogenicity [42]. Overall, the costs of production increase with the lenghth of the amino-acids chain. In addition, a complex control and characterization are simpler. Furthermore, very short peptides have better tunability, bio- and cytocompatibility (non-hemoliticity and non-cytotoxicity) [95], biodegradability, and non-immunogenicity, in comparison with their longer analogs. They can support the growth of diverse cells and their differentiation [96]. As a result, structural optimization is easier. Ultra short peptides are more amenable to oral delivery. They contain necassary molecular information on spontaneous self-assemble into the ordered nanostructures [97]. Fluorenylmethoxycarbonyl(Fmoc)-diphenylalanine is a good example of highly ordered peptide (hydrogel) with antimicrobial activity $[98,99]$ leading to the acceleration of wound healing [100]. Ultra-short nanoparticles can overcome the drug problem related to low half-life. As an example, encapsulation of curcumin in the form of nanocarrier can be used in a "controllable release" way to repair brain tissues as a promising drug in neurodegenerative diseases [101]. Moreover, ultra-short peptides are suitable for many bioapplications, innovative nano-theranostics (either therapeutic or diagnostic), especially in cancer cell growth inhibition, and advanced smart system formulations [102-106]. The latter include oral administration which increases drug efficacy and safety.

The simplest cyclo-peptides, also known as 2,5- (and 2,3- or 2,6-) diketopiperazines (DKP), piperazine-2,5-diones, 2,5-dioxopiperazines, and dipeptide anhydrides, are another important issue. They have amazing advantages in drug discovery due to their extra features, inter alia superior rigidity, three-dimensionality, higher cell permeability [107], and diverse bio-activities: Anticancer, antiviral, antioxidant, in neurodegeneration prevention, quorum sensing, cell-cell signaling, as drug delivery systems (e.g., in connection with cell-penetrating peptides) and so on [108-110]. DKPs are widespread in nature. They occur either in the marine and terrestrial environment, in microorganisms or high species, 
or in food and drugs [111,112]. In the latter case, DKPs are inner cyclization products of bio-active substances, e.g., ACE inhibitors [113-122]. Noteworthily, they have similar pharmacological profile as corresponding drug molecules. They were found in the central nervous system, gastrointestinal tract, and blood [123]. Interestingly, they played a key role in the origin of life $[112,124]$. The growing interest in these simplest natural cyclo-peptides is noticeable due to their huge potential in future therapies. 2,5-DKPs are observed in almost 50 bio-complexes deposited in the Research Collaboratory for Structural Bioinformatics Protein Data Bank (RCSB PDB) [125] (Figure 3).

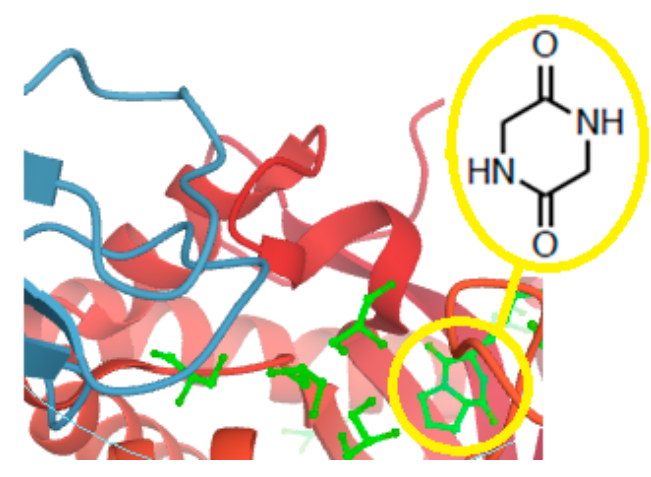

Figure 3. Bio-complex containg 2,5-DKP moiety [1O6I.pdb].

Generally speaking, short peptides are gaining more and more popularity. Exploration of their new modifications seems promising for new advanced research and will be the key to innovative smart bio-medical applications [126].

\subsubsection{Nanoengineering and a Supramolecular Approach}

Supramolecular chemistry ("chemistry beyond the molecule") is a bottom-up approach to the formation of well-ordered structures in the nano- (and the micro-) scale. Their adaptable, controllable, self-healing, and bio-physico-chemical stimuli-responsive properties induced via non-covalent interactions (electrostatic, hydrogen bonding, $\pi-\pi$ stacking, van der Waals or hydrophobic) are highly appreciated [123,127-132]. They have the dynamic nature and provide a firm basis for the structure and functioning of living systems. Notably, bio-systems are controlled by a plethora of supramolecular interactions. The formation of deoxyribonucleic acid (DNA) double helix via H-bonding interactions between the nucleo-bases or the folding of proteins into tertiary and quaternary structures is a good example of supramolecular assemblies. The self-assembly is a spontaneous, reversible, and ubiquitous process $[98,127]$. Self-assembling peptides are favorable platforms for the development of next-generation smart therapies. Minor structural changes can facilitate the generation of new assemblies. Modified peptides with aromatic amino acids or functionalized side chains (e.g., Fmoc) promote additional stacking interactions (Figure 4), which are helpful in the self-assembly process. Peptide-based bio-functional supramolecular materials (nanomedicines, hydrogels, drug delivery vehicles, gene or drug carriers, biomimetic-cell culture scaffolds, tissue-engineering systems, biosensors, emulsifiers, peptidomimetic antibiotics, bioimaging nanoprobes, three-dimensional (3D) bioprinting inks, vaccine adjuvants) have low toxicity and high biocompatibility and are useful in various applications, like drug delivery, tissue engineering, immunology, cancer therapy, and stem cell culture $[38,95,101,131-136]$. Supramolecular nanotherapeutics have better stability and efficacy, which helps to overcome problems related to peptide poor biostability and short plasma half-life. Nanoparticles' conjungtion with inter alia tumor-homing peptides is an attractive avenue for tumor-targeted therapy $[136,137]$. The advances in the synthesis of supra-molecular assemblies prompt the development of theranostics (which possess specific smart features, such as programmability, multifunctionality, sensitivity, precise selectivity, biosafety) and are promising agents for personalized, smart medicine $[126,138,139]$. 


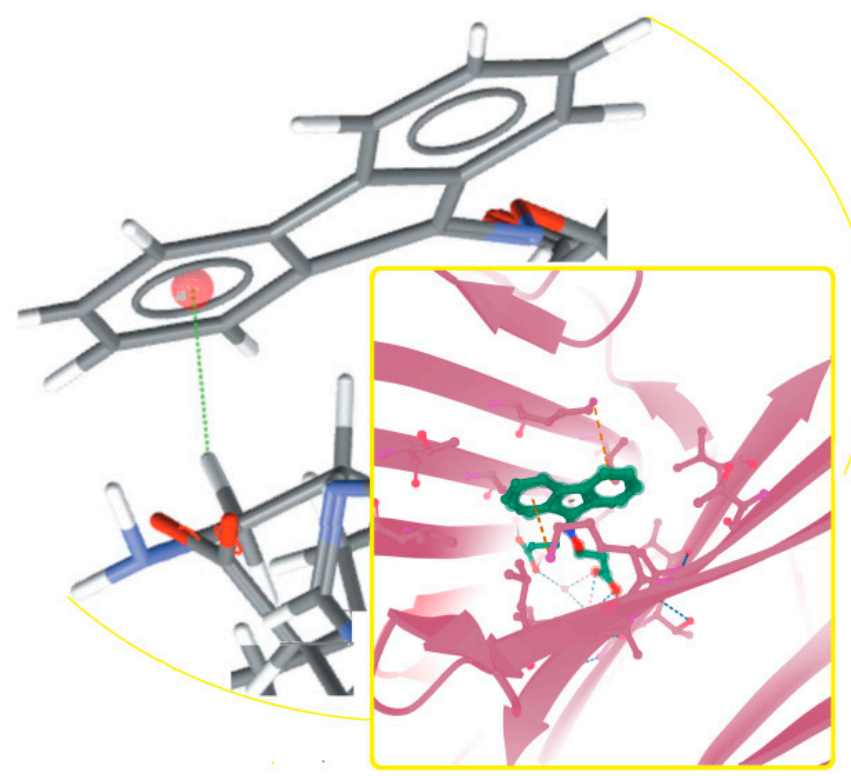

Figure 4. Bio-complex showing the C-H $\cdots \pi$ Fmoc interaction (PDB code 3gs4) [131].

\section{Synthesis}

\subsection{Advances in the Synthesis of Short Peptides and Modified Amino Acids}

The synthesis of modified amino acids and short peptides is based on reactions of functional groups. An example of modified amino acids at $\alpha$-carbon atom could be $\alpha$-hydroxymethylvaline [128], while 4-aminopyroglutamic acid can serve as cyclized dipeptide unit [140].

The typical chemical peptide synthesis requires the condensation reaction of the carboxyl group of one amino acid with the amino group of another. The only two approaches to a peptide synthesis are the synthesis in solution and the solid-phase synthesis (SPPS). In each of them, other steps besides peptide bond formation and/or deprotection, like introduction of main- and side-chain modifications, are available. The liquid-phase approach is now used mostly for the synthesis of short peptides up to tetrapeptide. During solid-phase peptide synthesis, each peptide is anchored at the C-terminus or side chain functional group to an insoluble/soluble polymer. In both cases, a single $\mathrm{N}$-protected amino acid unit is coupled to the free N-terminal amino group of growing peptides. After deprotection, which reveals a new amino group, another amino acid may be attached. Once synthesis is complete, the desired peptide is cleaved from the resin. Usually, this cleavage step is performed with acids of varying strength. Any functionalized polymer could be used as a solid support, like for instance styrene cross-linked with 1-2\% divinylbenzene [141], which is a popular carrier resin in SPPS. Other common gel-type supports include polyacrylamide and polyethylene glycol (PEG).

In solution peptide synthesis, each step requires precise product purification using gel chromatography or crystallization. In contrast, in SPPS purification is performed as a simple washing of the peptide attached to the polymer. This allows to design peptide synthesizers and automate the synthetic procedure.

The most commonly used peptide coupling reagents can be divided into two classes: Older reagents—carbodiimides and newer — salts of 1-hydroxy-benzotriazole ( $\mathrm{HOBt}$ ) and its derivatives. A danger of racemization during carbodiimide activation can be circumvented through the addition of 'racemization suppressing' additives such as triazoles (HOBt) and its derivatives (for example 6-Cl-HOBt) or 1-hydroxy-7-aza-benzotriazole (HOAt). A more recently developed additive for carbodiimide coupling with comparable coupling efficiency to HOAt is ethyl cyanohydroxyiminoacetate (Oxyma) [142]. As newer and commonly used reagents, there are compounds contained in the structure $\mathrm{HOBt}$ (HBTU/TBTU/PyBOP), HOAt (HATU), 6-ClHOBt (HCTU). Their iminium, uronium, 
or phosphonium salt of a non-nucleophilic anion (tetrafluoroborate or hexafluorophosphate) act as coupling reagent with the ability of lowering racemization process [143].

The amino acids have to be orthogonally protected during any chemical reaction, because of the presence of two or more reactive centers. In typical peptide synthesis, orthogonal but permanent protection is necessary for the amino acids'side-chain functionalities. Another class of protecting group is required for temporary protection of the $\alpha$-amino group. The temporary protecting group is being cleaved repeatedly while the permanent protecting groups have to withstand $\mathrm{N}$-deprotection conditions. When the synthesis is complete, they can be removed from the final peptide separately or simultaneously. Two principle orthogonal protecting group schemes are utilized in solution and/or solid phase synthesis: So-called Boc/Bzl (tert-butyloxycarbonyl/benzyl) and Fmoc/t-Bu (fluorenylmethylenoxycarbonyl/tert-butyl) approaches [144]. The Boc/Bzl-strategy requires side chain protecting groups, which should be stable during repetitive trifluoroacetic acid treatment. SPPS can be automated far more conveniently for Fmoc/tert-butyl (tBu) than for Boc/Bzl strategy. The advantage of Fmoc is that it is cleaved under very mildly basic conditions, but it remains stable under acidic conditions. This allows the use of mild acid-labile protecting groups, such as Boc and tBu groups, to be used on the side-chains of amino acid residues of the target peptide. Among other protecting groups recommended for special cases are for example allyloxycarbonyl (Alloc) for amino group and allyl ester for carboxyl group. There is always the possibility for their selective removal in the presence of Fmoc/tBu protections.

Solution phase synthesis as well as polymer supported synthesis can be utilized for the modification of amino acids and/or amide bonds. Nowadays, among popular modifications are all kinds of cyclization. Peptides can be cyclized on a solid support and/or in a solution with any coupling reagent. The disadvantage of the solution phase cyclization is a substrate high dilution necessity to limit the possible reactions to intramolecular one. The solid-phase synthesis of head-to-tail cyclic peptides is not limited to attachment through Asp, Glu, or Lys side chains. For example, cysteine has very reactive sulfhydryl group, which can be utilized as an anchoring point.

\subsection{Short Difficult Peptide Synthesis}

Although many peptides are routinely synthesized by SPPS, a certain kind of peptides is still difficult to be prepared. Such peptides are called "difficult sequence-containing peptides" [145]; even pentapeptides such as Ac-Val-Val-Ser-Val-Val- $\mathrm{NH}_{2}$ are known as an example. During the chain elongation, intra-/inter-molecular hydrophobic interactions and/or hydrogen bondings cause aggregation of protected peptides on the resin to induce incomplete coupling and deprotection. Furthermore, after final deprotection, hydrophobic peptides hamper HPLC purifications using $\mathrm{H}_{2} \mathrm{O}-\mathrm{MeCN}$ system. Modifying the main chain amide bond by e.g., pseudoproline (YPro) method [146] or O-acyl isopeptide method [147-149] often solves such problems. In these methods, main chain amide causing the undesired secondary structures is protected or modified to improve SPPS efficiency. For example, diabetes mellitus-related amylin is difficult to be prepared by the traditional Fmoc SPPS but was synthesized successfully with the aid of YPro structure $[150,151]$. In the UPro method (Figure 5), side chain of Ser/Thr/Cys in the difficult peptide is protected as Pro-mimicking "YPro" during SPPS and final trifluoroacetic acid (TFA) treatment liberates native Ser/Thr/Cys. Because N-alkylated amide cannot become a hydrogen bond donor and $\mathrm{N}$-alkylation of the amide bond affects the cis/trans ratio of the amide bond, this modification drastically changes secondary structure of the growing protected peptide on the resin $[152,153]$. The $\Psi$ Pro method successfully applied to the synthesis of short cyclic peptides as well $[154,155]$. As described above, during TFA-mediated final deprotection reaction, the native peptide is released. This tracelessness is a strong point but sometimes becomes a weak point; if the native peptide is hydrophobic, the following highperformance liquid chromatography (HPLC) purification would be difficult. To overcome it, the $\mathrm{O}$-acyl isopeptide method was developed (Figure 6). In this method, the target pep- 
tide is synthesized in a form of an $O$-acyl isopeptide, which contains an $O$-acyl isopeptide bond instead of the native $\mathrm{N}$-acyl peptide bond at a hydroxy group-containing amino acid residue, e.g., Ser or Thr. Namely, in this method, the main chain $\alpha$-amide is changed to a $\beta$-ester bond, which is not a hydrogen bond donor and has no cis/trans-causing rotation barrier. Thus, incorporation of the isopeptide structure drastically changes the secondary structure to increase the efficacy of peptide preparation during chain elongation in a similar manner to the $\Psi$ Pro method. Meanwhile, in contrast to the $\Psi$ Pro method, such an O-acyl isopeptide is stable under acidic conditions or as a powder (e.g., a lyophilized TFA salt) and the target peptide can be quantitatively obtained by a quick and one-way $\mathrm{O}$-to- $\mathrm{N}$ intramolecular acyl migration reaction under neutral conditions from the corresponding $O$-acyl isopeptide. Thus, hydrophobic peptides can be efficiently purified by HPLC (high performance liquid chromatography) at the $O$-acyl isopeptide stage [156]. The $O$-acyl isopeptide can be readily synthesized with $O$-acyl isodipeptide units [157-159]. Isodipeptide units have enabled routine application of the $O$-acyl isopeptide method by omitting the often-difficult esterification reaction on a resin. So far, many difficult sequence-containing peptides were synthesized by this method. Firstly, this method successfully applied to the synthesis of difficult pentapeptides (Ac-Val-Val-Ser-Val-Val- $\mathrm{NH}_{2}$ [147] and Ac-Val-Val-ThrVal-Val- $\mathrm{NH}_{2}$ [157]). Later, Cys was used instead of Ser/Thr as the S-acyl isopeptide method to prepare Ac-Val-Val-Cys-Val-Val- $\mathrm{NH}_{2}$ [160]. Since then, e.g., Alzheimer's disease-related amyloid $\beta$ peptide 1-42 (A $\beta 42)$ [40,161], amylin [162], vaccine peptide [163], insulin derivatives [164-167], and collagen peptide [168] are efficiently prepared by the $O$-acyl isopeptide method. Especially, in case of highly aggregative $A \beta 42$, isoA $\beta 42$ was confirmed being monomeric without any pretreatment [169]. The $O$-acyl isopeptide method is also applied to the peptide cyclization and segment condensation [170-174]. As described in this section, the YPro method and the O-acyl isopeptide method will assist Fmoc SPPS of difficult peptides in future.

(A)

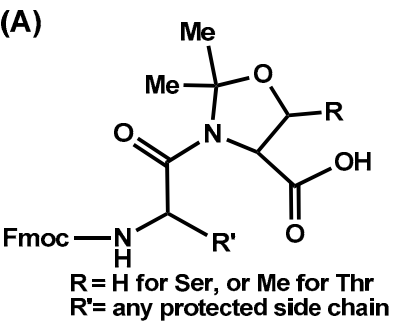

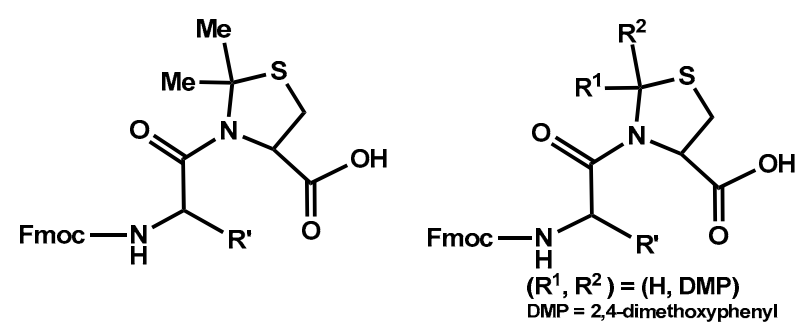

(B)

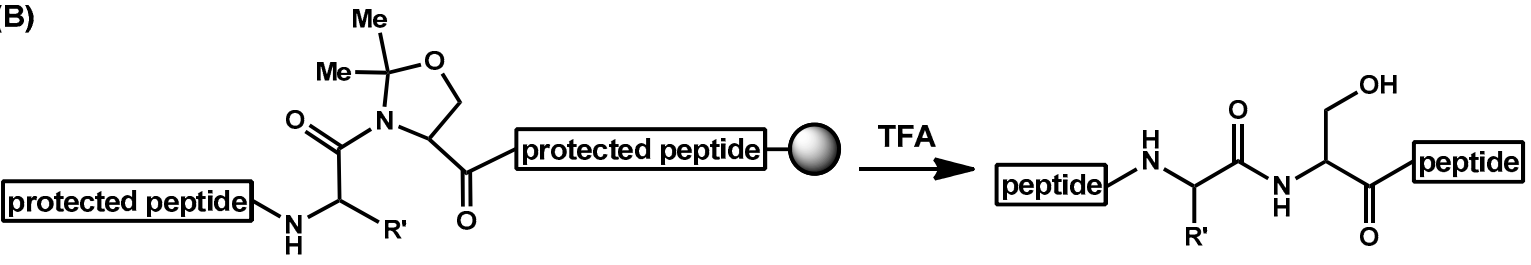

Figure 5. (A) Structures of Fmoc-protected YPro dipeptide units for Fmoc solid-phase synthesis (SPPS), (B) general scheme of $\Psi$ Pro-aided SPPS. 
(A)

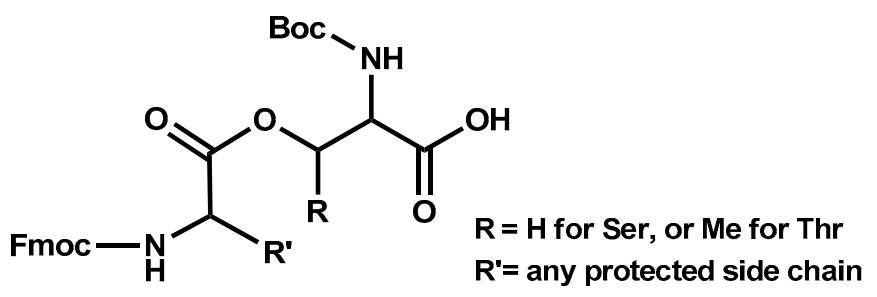

(B)<smiles>[R]C(NCCCOC(=O)C(C)C)C(=O)OCC(NC(=O)OC(C)(C)C)C(=O)CCCCC</smiles>

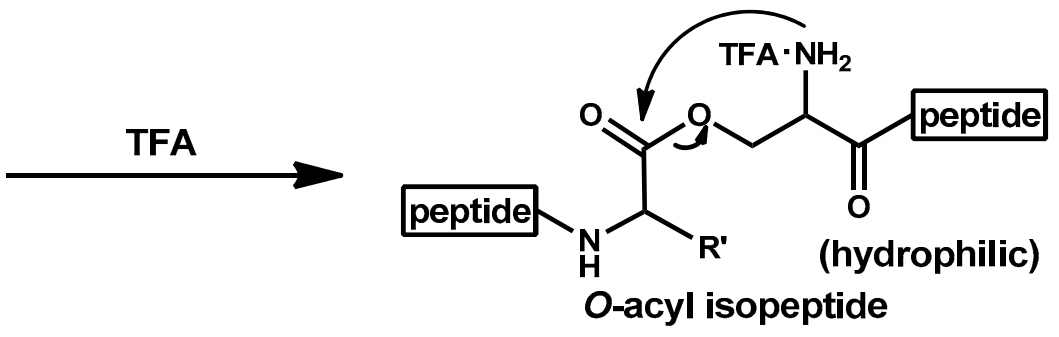

neutral condition<smiles>[R]C(NC(=O)C(CO)NC(=O)C1CC2CCCCC21)C(=O)N1CCCCC1</smiles>

Figure 6. (A) Structure of the O-acyl isodipeptide units for Fmoc SPPS, (B) general scheme of the $\mathrm{O}$-acyl isopeptide method.

\section{In Silico Studies}

\subsection{Geometry Optimization, Conformational Analysis}

In peptides and proteins, individual amino acids are linked together through peptide bonds. The peptide bond is planar with a significant double bond character, which prevents rotation. Thus, bond rotation in the short peptide backbone is only possible for the bonds on either side of the peptide bond. Molecular modeling tools allows constructing a 3D structure of a short peptide on a computer [175]. Once the structure is built, the process of geometry optimization should be carried out. The main objective of this process is to find the lowest energy conformation. Conformations with the lowest energy correspond to the most stable molecules. However, methods for finding minima normally can find local minima only. Therefore, to find the global minimum you must check various possibilities of geometrical arrangement to see which one is the global minimum on the multidimensional potential energy surface. One of the possibilities for scientists to do this is to create a potential energy surface (PES). A short peptide consisting of to 50 amino acids has many degrees of freedom and consequently a complicate PES. The geometry optimization of short peptide can be carried out using both quantum chemical and/or molecular mechanic methods. Over the past decades, novel quantum chemical methods have been developed that are capable of treating peptides at a high level of electron correlation [176-179]. Benchmark quantum chemical computations were also used to determine the accuracy of force fields in ranking compact, low-energy peptide structures $[176,178,180]$. However, achieving a reasonable description of a potential energy surface for thermal body tempera- 
ture (i.e., $\mathrm{RT}(310 \mathrm{~K})=0.616 \mathrm{kcal} / \mathrm{mole}$ ) exceeds the limits of modern force fields $[181,182]$. The structure obtained by energy minimization, however, is not necessarily the most stable conformation. Energy minimization will stop when it reaches the first stable conformation, and it usually encounters a local energy minimum. The minimization program has no manner to identify that there is a more stable conformation and converge the optimization process to a global minimum. To identify the most stable conformation of peptide it is necessary to generate different conformations and compare their energies. There are two methods of doing this, using molecular dynamics and/or stepwise rotation of bonds (conformational searching). Conformational searching is feasible for small oligopeptides only. When the number of rotatable bonds exceeds 5 , the entire conformational space of a molecule can become extremely large. In recent years, the methods of molecular dynamics were increasingly used to gain insight into the structure/function relationships in short peptides and proteins [183-187]. One of the key questions to be answered when checking the applicability of molecular dynamic simulations for peptides and/or proteins is the extent to which the simulations appropriately sample the conformational space of these molecules. If a given property is poorly sampled over the molecular dynamics (MD) simulations, the results obtained have limited usefulness [184]. To improve the sampling efficiency, new techniques were developed $[184,185,187]$. All-atom molecular dynamic simulations can predict structures of peptides and other peptide foldamers with accuracy of experiments $[187,188]$. Thus, MD simulations are a useful tool for prediction and/or reproduction of experimental 3D structures of small proteins.

\subsection{Modelling of Short Peptides}

The growing interest in peptide research results from recent successes in designing peptide sequences of therapeutic value. At present, more than 60 peptide drugs have been approved for use, with hundreds being in clinical trials. A number of new methodologies, both experimental and in silico, have been developed to design active peptide sequences and analyze peptide-protein interactions. The above-mentioned issues are discussed in a recent comprehensive review [44]. Here, we concentrate on the problems encountered both on modelling as well as practical sides. From the theoretical point of view, they result mainly from the intermediate size of peptides-neither relatively exact calculations for small molecules, nor very approximate but often successful methodologies used for protein-protein recognition, work properly for them. This is because the size and flexibility of peptides are prohibitive for exact calculations on the one hand, excluding the error-compensation mechanism, which we benefit from in addressing protein-protein recognition problems on the other. The practical biological problem results from many roles short peptides play in the living cells, many of which are not understood properly until now. It may happen that the designed peptide is either: The (folding) inhibitor of the essential protein or protein-protein (interaction) or protein function inhibitor also interacting with a different protein that it was designed to bind to; executes a biological function for reason which is not meant or understood. There are numerous examples of these effects, e.g., the peptide corresponding to the (83-93) segment of human immunodeficiency virus (HIV) protease interferes with the formation of the (post-critical) folding nucleus and inhibits folding of the protein [189], and native interface peptide fragments can be used as proton-pump inhibitors inhibitors (PPI). It is reasonable to assume that protein degradation products can affect PPIs in a similar manner [190], whereby short peptides can affect cellular processes in a way beyond explanation at the current state at knowledge e.g. there are more than 1700 peptides (sometimes fragments of angiotensinogen) known to lower arterial hypertension [191] — the mechanism of their action is unknown. In addition, our limited experience in targeting PPIs with peptides in bacterial cells for therapeutic purposes [189] shows that a significant fraction $(\sim 20 \%)$ of designed peptides is deadly for unknown reason.

In conclusion, interactions of peptides (both native and designed) are of great importance for the metabolic processes of the living cells. Their full understanding requires 
further progress on both modelling and thermodynamic aspects of their interactions as well as understanding the peptide content of cells coming from both synthetic and protein degradation corners.

\subsection{Peptide Interactions with Lipid Bilayers Using Molecular Dynamics Simulations}

Many biological processes are associated with the peptide interaction with lipid membranes. Peptides exert their action after the adsorbtion or insertion in the bilayer by different mechanisms [192]. They could promote lysing or permeabilizing the membrane, attaching to larger membrane proteins, or self-aggregate (forming pores for instance). The access to the molecular scale through simulations of peptide-membrane interactions could help to understand and design short peptides to be used as bioactive agents.

Nowadays, there are reliable models to investigate these problems through computer simulations, such as Molecular Dynamics technique [193]. Molecular dynamics simulation could help to study problems of many bodies based on classical mechanics. Within this approach, Newton's equations are solved numerically [194]. The main advantage is the realistic simulation of materials through the simplification by potentials with analytical form. Due to the development of fast and efficient methods for treating long-range electrostatic interactions, significant improvement in computer hardware, algorithms, and reliable force fields.

Here we focus on two molecular description scales: Atomistic and coarse grain (CG). The main difference between them is that in an atomistic scale all the atoms are represented, whereas in a CG scale, atoms are grouped in beads [195]. In this way, CG models allow the reduction of the degree of freedom and the integration of Newton equations in a higher time step, due to the elimination of high-frequency vibration modes [196]. Figure 7 shows illustrative snapshots of all atom representation of a lipid bilayer and a coarse grain representation of a liposome, both in the presence of short cationic peptides.

A)

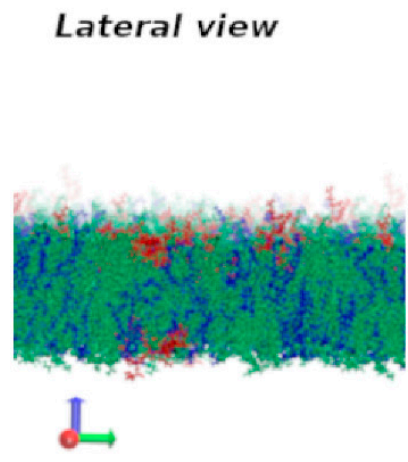

\section{Lipid bilayer}

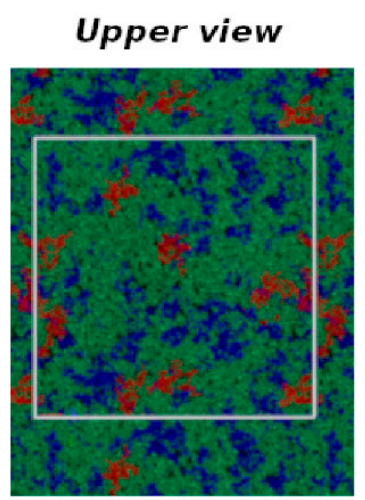

\section{B) Vesicle}

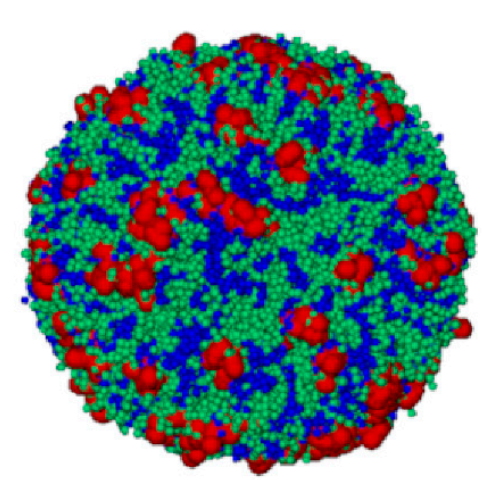

Figure 7. Representative snapshot of cationic peptides (red) adsorved into POPG (green)/POPE (blue) surfaces. Simulations were carried out using: (A) All atom model of Lipid bilayers and (B) Coarse grain model of vesicles. Water and ion sites were removed for visualization purposes.

What we can get from simulations of peptide interaction with lipid bilayers?

Using MD simulation at the atomistic and CG levels could bring very valuable information on the short peptide-membrane interaction. We mention here the issues and consider that this type of methodology has its contributions and challenges.

\subsubsection{Peptide Affinity Dependency on Membrane Composition}

The partition and insertion of single peptides in membrane of different composition have been broadly investigated using unbiased MD simulations at both description levels, with very successful results [197]. Within this technique, it is possible to access 
to the molecular details and identify specific interactions (hydrogen bond, salt bridge, cation $\pi$ ), peptide conformation, as well as bilayers properties associated with the interaction (induced defects with a variety of morphologies, stiffness, fluidity, etc.).

\subsubsection{Free Energy Calculations through a Peptide Reaction Path}

Important information could be obtained by calculating, for instance, the free energy through a given path for the peptide translocation along the bilayer. For bilayers, the natural path is the $z$ direction (normal to the bilayer). The use of enhancement of the sampling of configurational space is well established where we can highlight that several methods such as umbrella sampling [198], adaptive biasing force (ABF) method [199], the WangLandau algorithm [200], steer molecular dynamics [201], and metadynamics have been proposed [202].

\subsubsection{Cooperative Effects}

Among the proposed mechanisms of lithic action of peptides in membranes is the formation of pores. The study of cooperative effects, such as a pore formation, is not an easy task. It is hard to access with enhanced MD techniques or applying an electric field. Combining CG [203] and atomistic [204] level MD simulations could be used to broadly sample the phase space. Thus, different initial conditions could help to explore this space. For instance, pre-assembled pores embbebed in lipid bilayers could bring information on their stability dependence with the bilayer lipid composition [204].

\section{Peptide-Based Therapies}

\subsection{Monocyclic, Bicyclic and Tricyclic Cell-Penetrating Peptides as Molecular Transporters}

CPPs have become a subject of major interest $[205,206]$ for the intracellular delivery of therapeutic agents because of the limitations associated with linear CPPs, such as endosomal entrapment, toxicity, poor cell specificity [207], poor stability and degradation [208], and suboptimal cell penetration. Several cyclic CPPs possess enhanced cell-penetrating ability and improved physicochemical properties and proteolytic stability. Some cyclic CPPs exhibit endosomal-independent uptake [209]. A few cyclic CPPs have been reported to have a nuclear-targeting property [209]. We have summarized below some of the monocyclic, bicyclic, and tricyclic CPPs containing arginine and other amino acids (Figure 8). We have reported the application of cyclic CPPs containing alternatively positively charged arginine and hydrophobic tryptophan residues, $[\mathrm{WR}]_{4}$ and $[\mathrm{WR}]_{5}$, as drug delivery tools and nuclear targeting tools in 2011 [209]. Several other monocyclic CPPs were engineered based on this template and were shown to be efficient molecular transporters for enhancing the efficacy of existing chemotherapeutic, antiviral, and antibacterial agents [210-219]. The monocyclic CPPs containing tryptophan and arginine residues were also used to conjugate with potential therapeutic agents. For instance, monocyclic peptides were conjugated with doxorubicin, paclitaxel, and camptothecin $[216,220]$ demonstrating localization of the drug moiety in the nucleus in case of doxorubicin. Adding to the previous work, we also demonstrated that several monocyclic peptides containing cysteine and arginine residues, such as cyclic $[\mathrm{CR}]_{4}$, significantly enhanced the cellular uptake of a cell-impermeable phosphopeptide (F')-Gly-(pTyr)-Glu-Glu-Ile (F'-GpYEEI) in the presence of endocytic inhibitors and sodium azide in the lymphoblastic leukemia cell line (CCRF-CEM) [218]. Furthermore, tryptophan and histidine-containing cyclic decapeptides $[\mathrm{WH}]_{5}$ demonstrated an increase of the intracellular delivery of a cell-impermeable phosphopeptide and an anti-HIV drug, emtricitabine [217]. In another effort, monocyclic [HR $]_{4}$ peptides were used as a molecular transporter and were able to double the permeability of $\mathrm{F}^{\prime}$-GPYEEI in human ovarian adenocarcinoma cells (SK-OV-3) cells [214]. Two bicyclic peptides containing tryptophan and arginine residues, namely $\left[\mathrm{W}_{5} \mathrm{G}\right]-\left(\right.$ triazole)-[KR 5 and FAM- $\left[\mathrm{W}_{5} \mathrm{E}\right]-(\beta-\mathrm{Ala})-\left[\mathrm{KR}_{5}\right]$, significantly enhanced the cellular delivery of cell-impermeable $\mathrm{F}^{\prime}$-GPYEEI in SK-OV-3. The confocal microscopy exhibited that the peptides were localized in the nucleus and cytosol [219]. Recently, we designed a tricyclic peptide $\left.[\mathrm{WR}]_{4}-[\mathrm{WR}]_{4}-\mathrm{WR}\right]_{4}$ containing 
alternate tryptophan and arginine in each ring that improved the cellular uptake of $\mathrm{F}^{\prime}$ GPYEEI and fluorescently labeled anti-HIV drugs, lamivudine (3TC), emtricitabine (FTC), and siRNA in the breast cancer cell line MDA-MB-231 [221]. A combination of tryptophan and arginine residues in the design provided a diverse class of cyclic CPPs with differential cellular delivery properties. These data revealed the potential of monocyclic, bicyclic, and tricyclic CPPs as molecular transporters and provided insights into the design of the next generation of peptides as drug delivery tools.
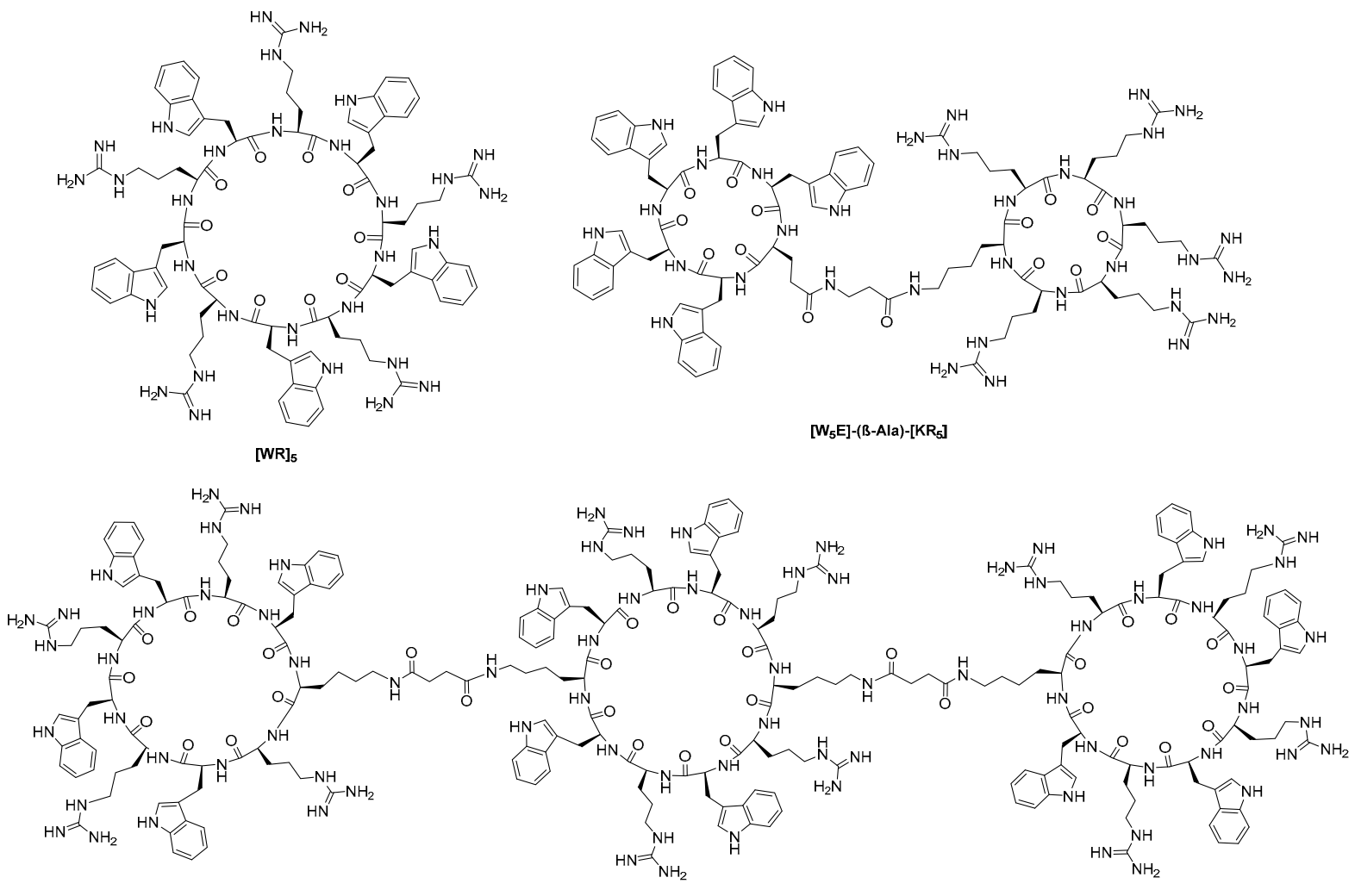

$\left.[\mathrm{WR}]_{4}-[\mathrm{WR}]_{4}-\mathrm{WR}\right]_{4}$

Figure 8. Monocyclic, bicyclilc, and tricyclic cell-penetrating peptides containing arginine and tryptophan residues as molecular transporters.

\subsection{Short Peptides in Gene Delivery}

A variety of oligopeptides have been proposed to overcome the extracellular and intracellular barriers in gene delivery. Peptide sequences can be incorporated in a complex gene delivery system (GDS) or used alone as a single carrier. Short peptides can be combined as constructs such as peptide dendrimers and potentially provide more than one feature in a single system. Peptides used in gene delivery can be categorized as (1) targeting peptides, (2) cell penetrating peptides, (3) endosome disruptive peptides, and (4) nuclear localization peptides.

\subsubsection{Targeting Peptides in GDSs}

Small peptide sequences have extensive applications as targeting moieties on the surface of GDSs. Conventional IgG antibodies $(\sim 150 \mathrm{kDa})$ are difficult and expensive to produce and introduce a high chance of immunogenicity. In contrast, small targeting moieties such as short peptides provide lower chance of immunogenicity due to lack of Fc region, increased ligand multivalency, and easy production by peptide synthesis methods [222-224]. Techniques such as phage display provides a means for identifying specific peptide sequences able to target selective tissues or cells $[225,226]$. A variety of peptides can be used either to target cell surface markers or subcellular elements 
in vivo. One of the most investigated target receptors on the cells, especially for cancer gene therapy are integrins, which are a class of cell adhesion molecules consisting of an $\alpha$ and a $\beta$ subunit. Targeting moieties against $\alpha_{v} \beta_{3}$ integrin, highly expressed on activated endothelial cells, contain a conserved arginine-glycine-aspartic acid (RGD) motif [227-231]. To achieve enhanced biological and pharmacokinetic properties, researchers have designed different RGD-containing peptide analogs and clustered RGDs [232,233]. Targeting ligands against other cell surface markers such as growth factor receptors (GFRs), transferrin receptors (TFRs), low density lipoprotein receptors (LRPs), acetylcholine receptors (AchRs), leptin receptors (LRs), and insulin receptors have been also investigated in targeted GDSs [234]. An important design factor in decorating GDSs with targeting peptides is accessibility of targeting moiety to interact with the target molecules effectively. Hindrance of the short peptide inside the GDS with loose interactions such as electrostatic interactions could lead to reduced targeting efficiency [235]. Other than cell surface, oligopeptides can be used to target the subcellular compartments such as endoplasmic reticulum, mitochondria, or Golgi apparatus. General nanoparticle targeting approaches to intercellular pathway/compartments can be found elsewhere [236-239].

\subsubsection{Cell Penetrating Peptides in GDSs}

Cell penetrating peptides (CPPs) are capable of translocating cargo therapeutics across the plasma membrane [240]. Physicochemical nature of CPPs can be cationic, amphipathic, or hydrophobic. Cationic CPPs are generally composed of short sequences of arginine or lysine. Some well-known examples are truncated Tat peptide (GRKKRRQRRRPPQ) [241], penetratin (RQIKIWFQNRRMK-WKK) [242], transportan 10 (AGYLLGKINLKALAALAKKIL) [243], and KALA (WEAK-LAKALAKALAKHLAKALAKALKACEA) [244]. Tat is a peptide fragment from residues 48 to 60 of the original transcription activating factor of human immunodeficiency virus (HIV-1) [241] and penetratin is obtained from a Drosophila homeodomain protein [242]. Tat-modified GDSs have shown enhanced cargo transport across several biological membranes such as cellular, endosomal, and nuclear membranes [245-248]. For peptides such as penetratin, the non-electrostatic interaction to the non-polar parts of plasma membrane is also of great importance [249-251]. The number of cationic residues, spacing between them, and inclusion of non-peptide elements such as hydrophobic lipid moieties were discussed as important factors in designing optimal synthetic CPPs [252-256].

\subsubsection{Endosome-Disruptive Peptides in GDSs}

Endosome-disruptive peptides destabilize the endosomal membrane leading to cargo release into the cytosol. Some provide membrane fusogenic features either $\mathrm{pH}$-dependent or $\mathrm{pH}$-independent. Sequences derived from the $\mathrm{N}$-terminus of the influenza virus hemagglutinin HA-2 are hemolytic at $\mathrm{pH} 4$, but not at $\mathrm{pH} 7[257,258]$. Protonation of the peptide acidic residues under acidic condition of endosomes would induce conformational changes leading to membrane binding and destabilization [258,259]. On the other hand, the hemolytic activity of melittin sequence is not pH-dependent [260,261]. MT20, a short peptide consisting of the first 20 residues of melittin, was designed to increase hemolytic activity at acidic $\mathrm{pH}$ and lower it at neutral $\mathrm{pH}$ [262]. Histidine-rich peptides are considered as another effective endosomolytic elements in GDSs. The imidazole ring in Histidine structure acts as a weak base that can be protonated at $\mathrm{pH} 6$ of endosomal compartment $[263,264]$. The $\mathrm{pH}$-dependent protonation of histidine and histidine-containing peptides result in $\mathrm{pH}$-buffering as well as fusogenic capabilities linked with membrane disruptive effects [265-268]. Branched histidine-rich sequences have provided high gene and siRNA transfection efficiencies $[269,270]$. Additional improvements were also observed in cases in which polymeric gene carriers were modified with imidazole- or histidine-rich sequences [265,271-273]. Amphipathic sequences such as the peptide, which consists of a tandem repeat of glutamic acid-alanine-leucine-alanine (GALA), was also employed in GDSs to provide $\mathrm{pH}$-sensitive fusogenic feature in acidic $\mathrm{pH}[274,275]$. 


\subsubsection{Nuclear Localization Peptides in GDSs}

Nuclear localization signals (NLSs) are reported to transfer cargos such as nucleic acids through the nuclear pore complex (NPC) of non-dividing or slowly dividing cells. They are believed to act as adaptors between the cargo and the importin-dependent nuclear transfer machinery. Short NLSs such as monopartite SV40 large T antigen with the sequence of PKKKRKV [274], or bipartite nucleoplasmin with the sequence KRPAATKKAGQAKKKK [276], have been reported to provide enhanced DNA transfection efficiency [277]. Peptides derived from $\mathrm{H} 1$ histones, protamines, ribonucleoprotein A1, and high motility group (HMG) proteins could also direct DNA to the nucleus $[278,279]$. NLSs have been extensively used to modify GDSs for improved transfection capability [280,281]. Due to the cationic nature of most of these peptides, some believe that the enhanced gene delivery efficiency observed with them, may be related to factors other than effective nuclear recognition [282], including better polyplex morphology and DNA binding strength.

\subsection{Taking Peptide Aptamers to a New Level}

Aptamers are molecules whose structures have been conformed to adapt to a target ligand in such a way as to optimise binding interactions between the aptamer and that ligand. Aptus in Latin means attached, adjusted. They can be constructed from a range of diverse chemical species and while nucleic acids are some of the first templates to have been employed for this approach, peptide aptamers are attracting increasing attention because of their biocompatibility, wide variety of physical characteristics, ability to introduce modifications using standard chemical techniques, and ease of large-scale manufacture. In this review, the different methods employed for designing peptide aptamers are discussed, together with new methodologies that can extend yet further their huge potential. Peptide aptamers can be broadly defined as peptides that have been adapted to interact with a specific target, usually employing a methodology that is able to select out high binders from a combinatorial library. Like nucleotide aptamers, the methods used to date to generate peptide aptamers have relied on genetic amplification mechanisms. The archetype of this approach is phage display [283]. Starting with a library of randomly generated amino acid sequences spliced into large scaffold proteins, in this case coat proteins of a bacteriophage, those phages that bind to a target can be separated from non-binders and those grown up in host cells to harvest those sequences with the strongest interaction. The power of the technique is that every individual sequence has, physically associated with it, the nucleic acid strand that codes for it, so that separating out the binding peptide separates out the coding nucleic acid at the same time. The same principle applies to all other methodologies employed so far.

Instead of being expressed on the phage surface, the library can be expressed on the surface of the bacteria growing the phage [284], or can be simplified to a cell-free presentation system where modifications made to the coding RNA (removal of the stop codon) result in a ribosomal complex in which mRNA, ribosome, and nascent protein remain physically attached to each other [285]. Extensions of this approach give rise to more stable protein-RNA conjugates in which the ribosome departs the complex after chemical ligation transfers the RNA directly to the protein [286].

At the same time, the technique has also progressed in the other direction, so that the aptamer target binding interaction actually takes place inside the cell that generates the aptamer [287], allowing for a more diverse set of read-outs than simply binding interactions.

Many different scaffold proteins are employed, chosen for their stability and their ability to accommodate stretches of foreign sequences while still folding into a single, unequivocal tertiary configuration. Certain scaffolds are more appropriate for hosting binding epitopes in the form of clefts (e.g., "affibodies" [287]), while others present sequences in loops (e.g., "knottins" [288] or "atrimers" [289], which can be modified subsequently by chemical means to increase their rigidity still further [290]. Aptamers have been created to an enormous range of targets and a number are now on the market, either as therapeutics [291] or diagnostic agents [292]. Their appearance is bound to increase rapidly, 
as they are highly biocompatible, can avoid being targets of the immune system, and can be manufactured by standard means.

As drugs go, however, they are still quite large, in order for the scaffold to fulfil the requirement for ease and reproducibility of folding. The composition of the structures obtained is of necessity confined to amino acids, (although a limited range of non-natural amino acids can be incorporated), and the initial discovery process, particularly for the cell-free systems, requires prior knowledge of the target structure to which the aptamer must bind.

Recently, however, a combinatorial amino acid structuring technology has been described that overcomes these limitations and that can take development of peptide aptamers to the next stage. In this technique (termed Mozaic), combinatorial libraries are produced by presenting mixtures of amino acids in a close-packed 2D mosaic array on the surface of nanoparticles [293]. The nanoparticles are actually micelles and the amino acids are the head-groups of the amphiphiles used to form the micelles, which form spontaneously when the amphiphiles are dispersed in aqueous media. Starting with a pool of the 20 amino acids (supplemented if desired by sugars, steroids, heterocyclics, and other non-natural amino acid residues) a suspension of micelles can be prepared that contains a predetermined selection from the starting pool, all mixed together in all possible random configurations on the surface of those micelles. A whole library of micelles can be prepared in this way, each with a slightly different combination of amino acid monomers.

Each member of the library can then be tested in a bioassay to determine which combination of amino acids is most effective at eliciting a certain desired behaviour. The micelles are non-toxic and biocompatible, so are amenable to use in assays involving cell culture. Because large amounts of the building blocks are readily synthesisable, micelles can be produced in large enough quantities that they can bring about changes in the behaviour of cells, rather than simply binding to them. Such changes can include cell differentiation, cytokine secretion, or induction of apoptosis. The process is iterative, so that after one amphiphile combination has been identified as positive, modifications can be made (e.g., reducing the number of components, or substituting them for others) to improve the response still further.

Because the read-out is a change in cell behaviour, results can be obtained even in the absence of knowledge as to what receptor needs to be targeted to achieve a desired effect and indeed, the technique can be employed to discover new, hitherto unknown receptors on cells whose stimulation can bring about the behaviour sought.

Under certain circumstances it is possible to test the activity of the micelles in in vivo models for disease. Normally, however, because of the labile nature of micelles, it is not possible to employ them directly as therapeutic agents, and their conversion to more stable peptide aptamers, particularly planar ring structures mimicking the planar surface of the micelle, gives rise to molecules that can change cell behaviour at very low concentrations [294]. Some of the most successful are cyclic peptides as small as 10 amino acids (Figure 9), stabilised by cross-ring hydrogen bonds. Their potential in vivo has been demonstrated in experimental models for rheumatoid arthritis [294].

\subsection{Peptide-Based Vaccines}

Short peptides play crucial roles in the immune system and are responsible for the transmission of most of the immunological information [295]. The immune system does not recognize an antigen per se, instead recognizing the B-cell, CD4+ (T-helper), and CD8+ (cytotoxic T lymphocyte, CTL) epitopes. B-cell epitopes (5-20 amino acids in length) are conformational (e.g., helical) and, as the antibody binding site, they are critical in the generation of humoral, antibody-based, immune responses. CD8+ epitopes (9-11 amino acids) are non-conformational and are recognized by MHC-I cell receptors. They trigger cellular immune responses and activate CTLs. CD4+ epitopes (typically 12-16 amino acids) are recognized by MHC-II receptors in antigen presenting cells (APCs) and are responsible for "help"; they further activate both humoral and cellular immune responses. 


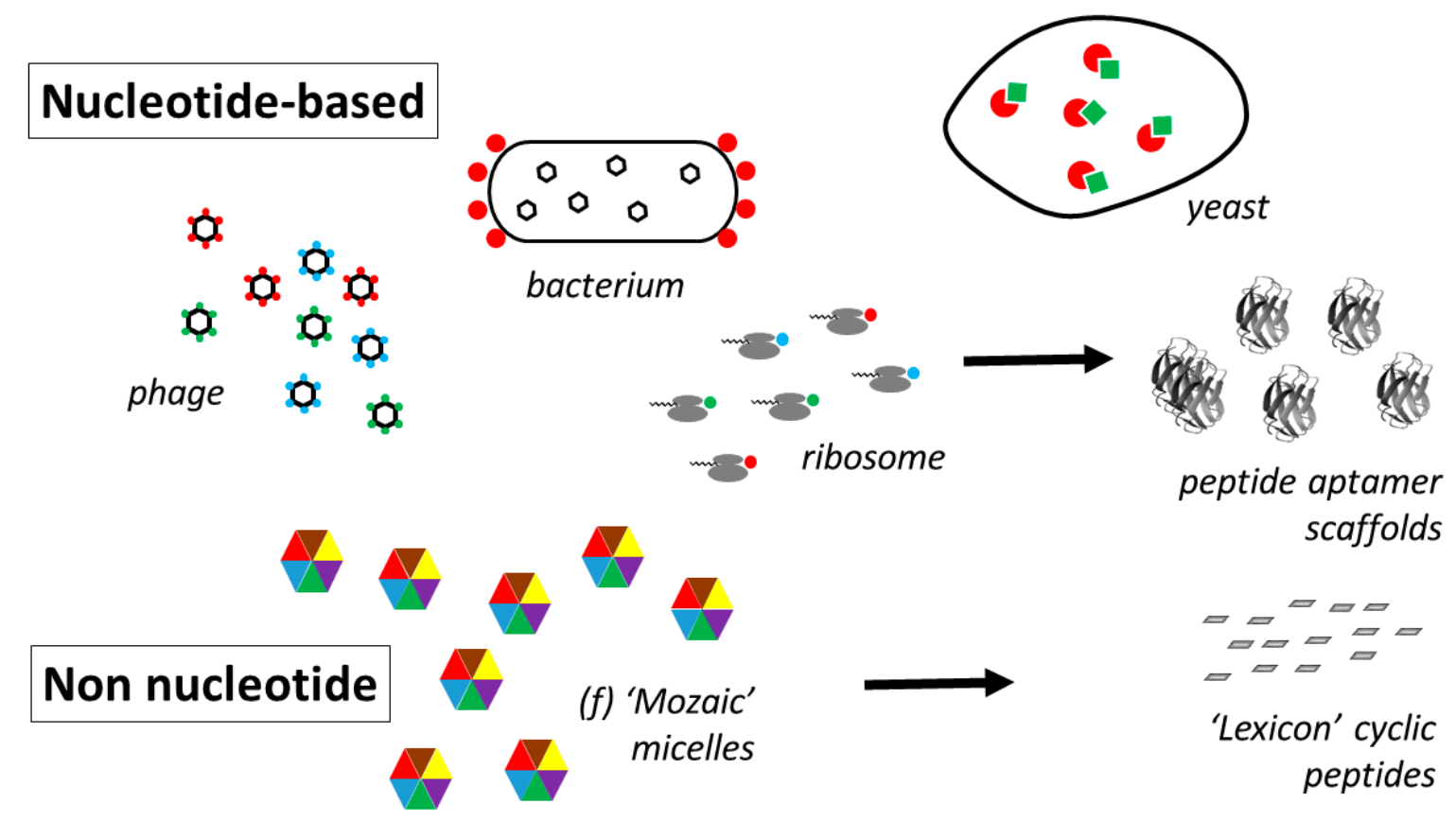

Figure 9. Presentation systems in peptide aptamer development.

Given this understanding, the most minimalistic vaccines can bear just those epitopes and still induce the desired immune responses. These vaccines, named peptide-based vaccines, have several advantages over classical vaccines (which are based on whole pathogens or their large fragments): (a) They induce precisely engineered epitope-specific immune responses; (b) they do not cause allergic, autoimmune, or excessive inflammatory responses; (c) they provide direct immune responses to non-immune dominant fragments of antigens; (d) they can be produced through chemical methods with high purity and reproducibility and can be precisely characterized in the same manner as small moleculebased drugs; (e) biological contamination is avoided due to chemical synthesis; and (f) they are more stable than whole pathogens or proteins and usually do not require "cold chain" storage or transport conditions [296,297].

However, peptides alone are poor immunogens and require immune stimulants (adjuvants) [298]. Many approaches have been investigated to stimulate and deliver peptidebased vaccines without the need for classical adjuvants (e.g., Alum) [299]. These delivery systems/adjuvants have been designed to: (a) Improve peptide delivery to APCs; (b) protect peptides against enzymatic degradation; (c) maintain the desired conformation (crucial for antibody-based immune responses); (d) create a depot effect at the injection site and control the release of antigen (mimicking natural local infection); (e) deliver vaccines to specific tissues (e.g., lymph nodes, spleen); (f) allow cross-presentation (mimicking viral infection); and/or (g) carry multiple epitopes covering different pathogen serotypes, stages in the pathogen life cycle, or even epitopes derived from different pathogens [300-302].

Interestingly, short peptides can also serve as adjuvants and delivery systems. For example, upon conjugation with a peptide antigen, Q11 peptide (QQKFQFQFEQQ) selfassembled into $\beta$-sheet fibrils. This strategy has been used to deliver vaccine candidates against malaria [303], tuberculosis [304], and group A streptococcus (GAS) [305]. Polyleucine (L15), when conjugated to B-cell epitope, self-assembled into nanoparticles. These particles induced the production of high antibody titers and protected model animals against GAS [306] and hookworm [307] infections. Polyglutamic and aspartic acids (E10 and D10) formed self-adjuvanting polyelectrolyte-based complexes when mixed with peptide antigen and trimethyl chitosan (TMC), while a simple mixture of antigen with TMC did not induce strong immune responses [308-310]. Cell-penetrating peptides have been used for the delivery of a variety of vaccines, mostly targeting cellular immune responses [311]. For example, muramyl dipeptide (N-acetylmuramic acid modified 
$L$-alanine- $D$-isoglutamine) was approved as an adjuvant for a Leishmania animal vaccine [312]. Peptide-based vaccine approaches are relatively new and no peptide-based vaccines are available on the market. However, a huge number of peptide-based vaccinestargeting practically all possible infectious diseases, including acquired immune deficiency syndrome (AIDS), malaria, and coronavirus disease 2019 (COVID-19) - are under development. Covaxx anti-COVID-19 peptide vaccine entered clinical trials and its UB-612 vaccine will be tested in phase II/III clinical trials in Brazil [313]. The number of peptide-based vaccines in clinical trials has grown significantly over the last decade; several of these, particularly those against cancers, have reached phase III [314,315].

\subsection{The Role of Short Peptides in Neurodegenerative Therapy}

Short peptides are a vital and promising tool in the study of neurodegenerative disorders (Alzheimer's, Parkinson's and Huntington's diseases, amyotrophic lateral sclerosis, prion diseases). They can be used in either diagnosis or further treatment. As an example, short peptide-based inhibitors of amyloid $\beta$ aggregation in Alzheimer's disease with reduced cytotoxicity are good drug candidates [32,33]. Notably, very short peptides, like diphenylalanine and related compounds such as tert-butoxycarbonyl derivative (Table 2 [126]), are the core recognition motifs of $\beta$-amyloid polypeptides $[98,126]$. Fibrillar dynamic self-assembly behaviour of short peptides, leading to amyloid-like supramolecular structures, is a key insight into the nucleation, oligomerization, and the physical properties of amyloid fibrils [126].

Table 2. Short peptides forming amyloid-like fibrils.

\begin{tabular}{cc}
\hline Name of Peptide & No. of Amino Acids \\
\hline diphenylalanine & 2 \\
$\alpha, \beta$-dehydrophenylalanine & 2 \\
Fmoc-diphenylalanine-konjac glucomannan & 2 \\
Ac-EFFAAE-NH2(AIP-1/2) & 6 \\
FFKLVFF & 7 \\
P11 (QQEFQWQFRQQ) & 11 \\
\hline
\end{tabular}

Theses very short peptides as well as cell-penetrating peptides are of relevance to the highly efficient drug delivery systems (to target cells and subcellular organelles) and the prevention of amyloid $\beta$ aggreagation [316]. Interesting and promising aspects of delivery strategy are peptide-based gel matrices to drug encapsulation [126]. Peptide-based therapeutic drugs induce the neuronal growth, modulate neurogenesis [317], and finally improve spatial memory. Their diversity prompts personalized therapies $[40,318]$.

\subsection{Immune Modulation Using Altered Peptide Ligands in Autoimmune Diseases}

Altered peptide ligands (APL) refer to immunogenic peptides where the $\mathrm{T}$ cell receptor (TCR) contact sites have been manipulated, resulting in altered T cell responses. As such, 1-3 amino acid mutations have been designed for immune modulation in autoimmune diseases (Figure 10) [319]. Primary biliary cholangitis is a disease characterized by inflammatory destruction of small bile ducts in the liver leading to cirrhosis. Autoantibodies and $\mathrm{T}$ cells are associated with primary biliary cholangitis. The E2 region of pyruvate dehydrogenase complexes 159-167 (PDC-E2) binds to HLA-A2, and substitutions of alanine at position 5 of PDC-E2 peptide 159-167 leads to antagonism, by reducing peptide specific effector functions of the CD8+ T cells [320]. Likewise, in myasthenia gravis, an autoimmune disease regulated by CD4+ T-cells, which recognize the peptide epitopes p195-212 and p259-271 of the human acetylcholine receptor alpha-subunit, single amino acid mutations are able to inhibit myasthenia gravis autoimmune responses in mice. APL of these peptides up-regulate tumor necrosis factor-beta and down-regulate interferon (IFN)-gamma and IL-2 by the native peptide specific CD4+ T cells [321]. 


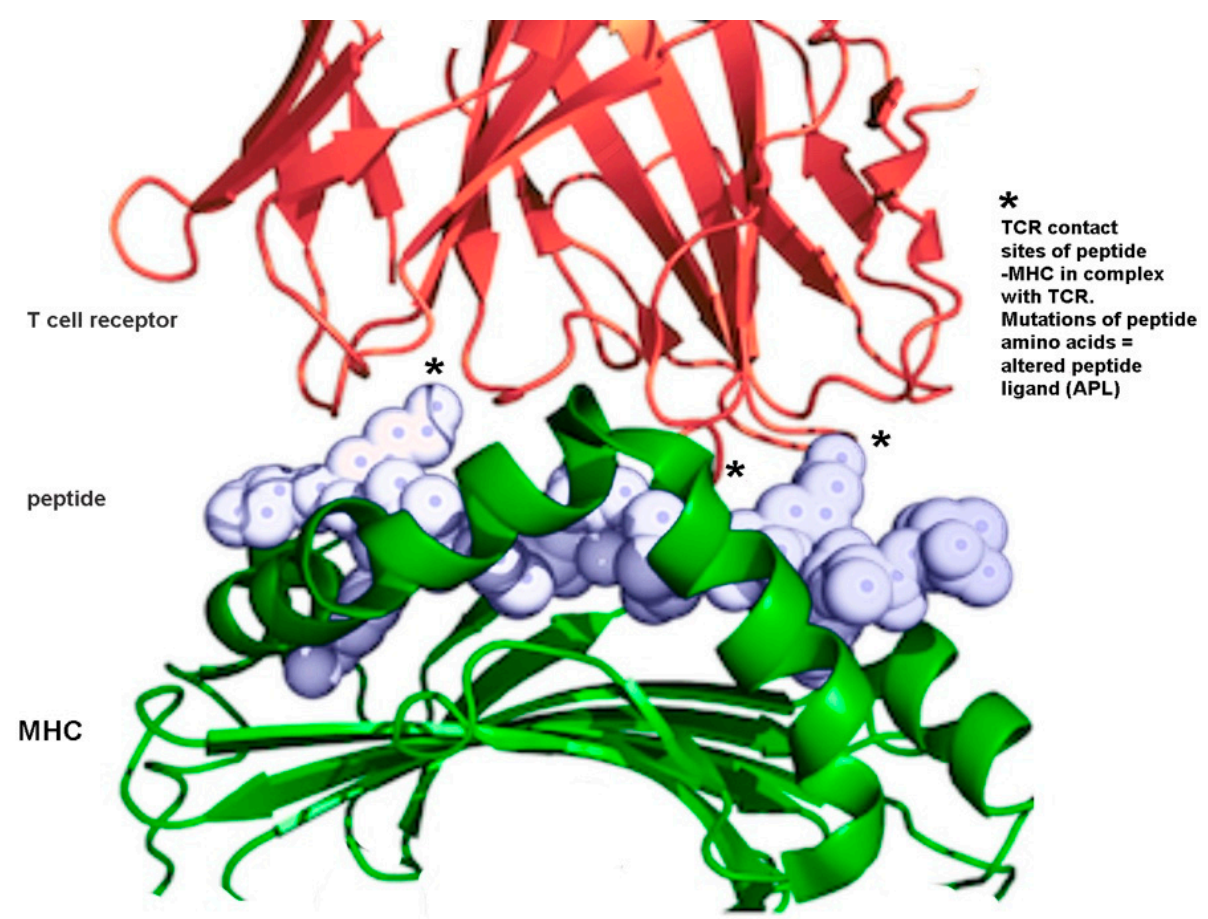

Figure 10. Major histocompatibility complex (MHC)-peptide-T cell receptor (TCR) trimolecular complex denotes amino acids from peptide TCR contact sites, where mutations result in APLs.

In addition, type- 1 diabetes is characterized as inflammatory destruction of betaislet cells within the pancreas by which autoantibodies, CD4+ T cells and CD8+ T cells, have been identified amongst other immune cells. Auto antigens have been identified, which include glutamic acid decarboxylase 65, non-specific islet cell auto-antigens, insulin, proinsulin, insulinoma antigen-2, imogen-38, protein-tyrosine phosphatase-2, zinc transporter- 8 , chromogranin A, pancreatic duodenal homeobox factor 1 , and islet amyloid polypeptide [322]. The $B$ chain of insulin epitope $B_{9-23}$ is recognized by autoreactive CD4+ T cells, which secrete high pro-inflammatory IFN-gamma. Mutating two TCR contact amino acids was able to induce secretion of anti-inflammatory IL-4, IL-5, and IL-10 [323]. Based on this data, the APL of B9-23 entered into human clinical trials in recent onset type- 1 diabetic patients and although in phase 1 it was shown to increase anti-inflammatory T helper-2 (Th2) cells over pro-inflammatory Th1 cells, in a phase 2 study, it did not improve beta-cell function [324]. Similarly, APL from imogen-38 peptide epitope 55-70 was able to inhibit proliferation of CD4+ T cells and mannosylation was more effective compared to non-mannosylated APL [325].

Multiple sclerosis is an inflammatory disease involving immune cell infiltration and destruction of the myelin sheath. CD4+ T cells, CD8+ T cells, macrophages, auto-antibodies, Th17 cells, and others are involved in the pathophysiology of multiple sclerosis [326-328]. Numerous auto-reactive CD4+ T cell epitopes have been identified against myelin basic protein, proteolipid protein, and myelin oligodendrocyte glycoprotein, and APL of some of the epitopes have been evaluated. In particular, myelin basic protein epitope 83-99 and the shorter peptide 87-99 (MBP87-99) with one or two amino acid mutations are able to stimulate Th2 CD4+ T cells and antagonize Th1 CD4+ T cells [76,329-331]. Mannosylation of APL further enhances Th1 to Th2 diversion in mice and to human peripheral blood mononuclear cells from multiple sclerosis patients [332,333]. An APL of the longer peptide, MBP83-99, was tested in human clinical trials in patients with multiple sclerosis [320]. CD4+ T cells were stimulated which secreted high levels of IL-5 compared to high levels of IFN-gamma prior to treatment. These results indicate that APL immune modulation in patients with multiple sclerosis can stimulate Th2 responses, diverting reactivity away from the potentially harmful Th1 type [334]. In other studies, peptides from human pa- 
pilloma virus containing part of the amino acid sequence (VHFFK) of MBP87-99 motif (VHFFKNIVTPRTP) induced experimental autoimmune encephalitis in mice, however, peptides from human papilloma virus type 40 (VHFFR) and human papilloma virus type32 (VHFFH) prevented experimental autoimmune encephalitis [335]. Hence, microbial peptides, differing from the core motif of the self-MBP antigen, MBP87-99, may function as natural APL in the modulation of autoimmune disease.

Dysregulated immune cells, in particular CD4+ T cells, are amongst the cause and consequence of autoimmune diseases. Altering the fate of the auto-reactive CD4+ T cells by either switching off pathogenic cells, or altering their cytokine profile from pro- to anti-inflammatory is one mechanism of managing disease progression. The APL concept, which can influence $T$ cell activation and polarization, has shown promise in animal models and in some human clinical trials as novel treatment modalities for auto immune diseases in the future.

\subsection{Relevance of Short Peptides in Stem Cell Research}

Stem cell therapies are part of regenerative medicine aimed at improving the quality of life through the fight with so far untreatable diseases. Short peptides are perfect candidates for the development of 2D and 3D stem cell-culture materials due to their excellent opportunities. First of all, peptides mimic the protein functions. They inter alia interact with DNA acting as regulatory factors. Oligopeptides imitate the extracellular matrix (the most important part of the stem cell niche), which influences the fate of the stem cell $[336,337]$. Short peptides play an important role in the transmission of bio-information, modulation of transcription, or restoration of genetically conditioned alterations being developed with age [317,338]. In other words, they have geroprotective properties. The self-assembling peptides in conjunction with stem cells are enable to regenerate damaged tissues [339]. They have relevance to the attenuation of the pathology of neurodegenerative diseases, heart failures, or arthritis [339]. Short peptides are involved in the regulation of proliferation and differentiation of stem cells into individual cell-types [340]. Good examples can be: Lys-Glu, Ala-Glu-Asp, Lys-Glu-Asp, Ala-Glu-Asp-Gly [317]. Modified peptides (e.g., by mentioned earlier Fmoc moiety) enhance differentiation activity. Peptide-based hydrogels are useful in controlling differentiation [341]. Very short peptides can penetrate the epidermis sending signals to cells. Peptides related to stem cells show great potential in the development of novel treatments, advance tissue regeneration, further rational design of the extracellular matrix-materials (as stem cell culture substrates), and organ engineering applications.

\subsection{Short Peptide-Based Anti-Viral Agents against SARS-CoV-2}

COVID-19 is an ongoing worldwide pandemic caused by SARS-CoV-2. So far, there are no specific antiviral drugs available for the treatment of this disease. However, a large number of small molecules displaying significant inhibitory activity against SARS-CoV-2 have been identified based on experimental and computational studies [342], among which many are short peptides and peptide-like compounds.

Generally, the peptide-based SARS-CoV-2 inhibitors target two proteins, namely membrane (M) and spike (S) proteins [343]. The former plays a crucial role in facilitating virus entry by mediating its interaction with the host cell receptor ACE2 and the latter (also called 3CLpro) is mainly in charge of the cleavage of viral polyproteins. Due to the high sequence similarity of different CoV 3CLpros, some known peptide-based HIV protease inhibitors have been used in clinical trials as the treatment of COVID-19, representative examples including lopinavir (1) and ritonavir (2) (Figure 11) [344]. Besides, some de nova designed 3CLpro inhibitors have also been identified based on structure-based rational design. For examples, Hilgenfeld and co-workers developed a series of $\alpha$-ketoamide derivatives (e.g., Figure 11(3,4)), which was proved to be potent inhibitor of the SARSCoV-2 3CLpro [345]; Liu, Jiang and co-workers discovered two peptidomimetic aldehydes (Figure 11(5,6)), which showed excellent in vitro activity against SARS-CoV-2 3CLpro [346]. 
These compounds showed good in vivo pharmacokinetic properties and safety, thus holding a great promise to evolve into anti-viral agent against SARS-CoV-2. In addition, a variety of peptide-based leading structures have been identified through virtual screening approaches, which may also serve as the starting point for the development of new therapeutics for COVID-19 [347,348].<smiles>Cc1cccc(C)c1OCC(=O)N[C@H](Cc1ccccc1)[C@@H](O)C(=O)[C@H](Cc1ccccc1)NC(=O)C(C(C)C)N1CCCNC1</smiles><smiles>O=C(/C=C/c1ccccc1)N[C@@H](CC1CCCCC1)C(=O)N[C@@H](CC1CCNC1=O)C(=O)NCc1ccccc1</smiles>

3

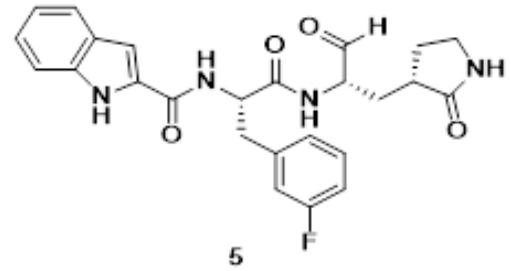<smiles>[R10]c1ccc(C[C@@H](C[C@@H](O)[C@H](Cc2ccccc2)NC(=O)OCc2cncs2)NC(=O)[C@H](NC(=O)N(C)Cc2csc(C(C)C)n2)C(C)C)cc1</smiles><smiles>Nc1cccn([C@H](CC2CC2)C(=O)NC(CC2CCNC2=O)C(=O)NCc2ccccc2)c1=O</smiles>

4

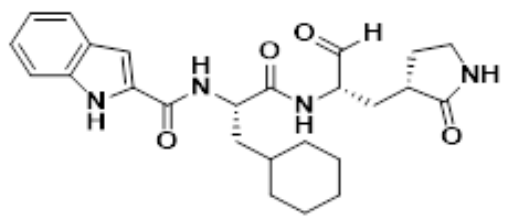

6

Figure 11. Selected peptide-based anti-viral agents against SARS-CoV-2.

The protein-protein interaction of the S protein of SARS-COV-2 and the host cell receptor ACE2 has also been viewed as an ideal target for the development of anti-viral agents against SARS-CoV-2. Particularly, the cryo-EM and co-crystal structures of the receptorbinding domain of SARS-CoV-2 with human ACE2 have been disclosed recently $[349,350]$, which paves the way to develop new entry inhibitors against SARS-COV-2. For example, a 23-mer peptide sequence derived from human ACE2 was designed and synthesized by Pentelute and co-workers, which can specifically bind to SARS-CoV-2-RBD with low nanomolar affinity [351]. Besides, some potential ACE2-based peptide inhibitors have been identified through computational approach and their efficacy needs to be further validated in practice $[352,353]$.

\subsection{Antimicrobial Lactoferrin-Based Peptides as Anti-COVID-19}

COVID-19 severity accrues due to its extremely high infection transmission rates [354]. Therefore, there is an urgent need for a novel, effective, and safe vaccine or drug to reduce the viral transmission rate and thus suppress the infection.

Different types of vaccines against SARS-CoV-2 infection have been under preparation [355]. However, some challenges related to vaccine administration safety have been of great concern. First, live or attenuated vaccines may recover their virulence leading to a high risk of disease recurrence to the vaccinee. Furthermore, transient immunosuppression may be induced resulting in the vaccinees' susceptibility towards infections [356]. Second, DNA vaccines may cause a mutation risk upon integration with the host genome. Third, synthetic peptides are of low immunogenicity. Fourth, mRNA vaccines may need 
further quality and safety evaluation to enter the pharmaceutical market. Finally, yet most importantly, it was reported that vaccines produced from full-length spike (S) protein against SARS-CoV-2 might be involved in liver damage [355]. Some studies reported that sequenced strains of SARS-CoV-2 evolved into two subtypes (L and S), which showed great variation in geographical distribution, transmission ability, and disease severity. It is, then, speculated that the production of an efficient, safe, fully clinically approved SARS-CoV-2 vaccine may not take less than many years. Besides, the probability of the vaccines endorsement by the relevant authorities is considered low [355]. Many studies reported that Antimicrobial Peptides (AMPs), short sequence peptides polymer ranging from 10-100 amino acids, positively charged, amphiphilic, might be considered as a promising solution to combat harmful microorganisms [357]. Lactoferrin (LF), as one of the AMPs, is an iron-binding glycoprotein located at the mucosal layers of the human body. LF is considered as the first line of defense against microbial infection, which may have the potential to boost the innate immune response against COVID-19 [358]. Furthermore, LF is a natural, safe, and effective antiviral drug, which is naturally produced, in human and bovine milk, beside its anti-inflammatory and antitumoral properties. LF prevents the viral infection by blocking the host cell receptors or binding to the virus particles [358]. Moreover, some studies showed that the usage of LF as an adjuvant to vaccines might enhance their antiviral activity, beside being considered as a safe alternative to other used adjuvants [358]. Therefore, it may be recommended to use the LF as an immunity booster against SARS-CoV-2, rather than counting on the insufficiently tested vaccines, in order to spare the required time for full testing and clinical approval of the required vaccine. Finally, it may also be recommended to use LF in conjugation with the produced vaccine to enhance its anti-COVID-19 activity.

\subsection{Peptides from Digestion of Proteins}

Food proteins are long-chain polymers of amino acids, encrypted into which are peptides with potential health benefits, which may be used for the treatment and management of chronic and severe degenerative diseases such as hypertension, diabetes, obesity, cancer, and metabolic disorders [359]. Bioactive peptides (BAP) from food proteins have the amino acid structure and sequences similar to those that convey various signaling mechanisms or hormones in our body. They are small molecular weight peptides usually around $5 \mathrm{kDa}$. They have high tissue affinity, specificity, and efficiency to interact with receptors, enzymes, and other biomolecules in the body to confer health promoting effects $[360,361]$. Some of these BAPs may be released in the gut when proteins are degraded by the digestive enzymes such as pepsin, trypsin, chymotrypsin, and peptidases. However, controlled enzymatic digestion of food proteins in vitro would release some of these BAPs, which can be isolated and purified for therapeutic use.

The enzymatic production of bioactive peptides in vitro is greatly influenced by factors such as the $\mathrm{pH}$, degree of hydrolysis (DH), enzymes used, enzyme/substrate ratio, temperature, hydrolysis time, and solvents used. It is well known that an abundance of hydrophobic amino acids, such as Gly, Val, Ile, and Ala, in the peptide sequences compared to the presence of other polar and charged amino acids, will contribute to the high bioactivity observed [361].

Bioactive peptides are naturally formed by the exogenous protease enzymes produced by microorganisms during fermentation. Some of the BAPs also have high antioxidant activities. Therefore, cultured milk products, fermented fruits and vegetables, and fermented meat and fish products are considered beneficial adjuncts in human diets.

\subsection{Nutraceuticals}

At present people ingest foods not just to cover their nutritional necessities; they also request healthy, natural, and convenient foods with biological activity. Interestingly, some plant proteins encrypt diverse peptides with beneficial effects on health. The most studied effects include anti-hypertensive, -cholesterolemic, -oxidant, -inflammatory, -cancer, 
-microbial, and immunomodulatory properties. Nowadays, different scientific areas have focused their research on the functional properties of foods and food products. Bioactive substances are known as components of foods that modulate metabolic processes, provide health benefits, and positive impact on the function of the body. A healthy diet is a key factor to prevent some diseases [362,363]. The intake of proteins is essential for maintaining a good health and it also provides bioactive peptides. Specific amino acids sequences encrypted in proteins in several foods have health effects, playing roles as fragment of the whole protein (epitopes responsible for interactions between proteins and antibodies) or being efficient after the release by proteolytic enzymes. Peptides with two or three amino acids pass easily through the gastrointestinal tract to the blood. Proteins are a source of bioactive di- and tri-peptides, among others, with certain biological activity [363-365]. Bioactive peptides have been known for several years and identified in plant and animal sources and their interest has increased in the last decades. They comprise positive health effects, i.e., on blood pressure and lipid metabolism, as well as analgesic, anti-thrombosis, anti-atherosclerotic and opioid agents. Some peptides have more than one activity. They are also useful to improve absorption of minerals [366-368]. Bioactive peptides are usually a product of the hydrolysis by gastrointestinal digestive enzymes (pepsin, trypsin, and chymotrypsin), or by in vitro producers with specific enzymes, temperature, or $\mathrm{pH}$. They may contain hydrophobic amino acids in their sequences, a positive charge, and the resistance to digestion by proteases and peptidases and a proline $C$ terminal. Small peptides with a dipeptide of proline-proline at their $\mathrm{C}$ terminal are more resistant to degradation by proteases and peptidases of the stomach, pancreas, or intestine. Large peptides may be active outside the intestinal epithelium. Recent studies of crop proteomic data revealed that at least 6000 proteins may harbour bioactive peptides [368,369].

\subsection{Marine Peptides}

Marine bioactive peptides of diverse bioactivities, encompassing anti-inflammatory, anticancer, and antioxidant activities, have been discovered from non-edible marine organisms and seafood processing by-products [370]. An interesting example is a hydrostatinSN1 (DEQHLETELHTHLTSVLTANGFQ), an anti-inflammatory peptide identified from the venom gland of sea snake Hydrophis cyanocinctus [371], see Figure 12. In vivo anti-inflammatory effects of the peptide have been demonstrated in murine models of lipopolysaccharide (LPS)-induced acute lung injury [372] and in dextran sulfate sodiuminduced acute colitis [371]. Hydrostatin-SN1 suppressed LPS-induction of pro-inflammatory cytokines, namely, tumor necrosis factor alpha (TNF- $\alpha$ ), interleukin- 6 , and interleukin- $1 \beta$, in mice. In vivo evidence and study on LPS-treated RAW 264.7 cells indicated the possibility of hydrostatin-SN1 exerting its effect by interfering with the extracellular-signal related kinase $1 / 2$ and nuclear factor- $\mathrm{kB}(\mathrm{NF}-\mathrm{kB})$ pathways [372]. In the murine colitis model, hydrostatin-SN1 exhibited its anti-inflammatory effect by binding to tumor necrosis factor receptor 1 (TNFR1), hence disrupting the interaction between TNFR1 and TNF- $\alpha$. This, in turn, inhibited TNF- $\alpha$-mediated activation of the NF- $k B$ and mitogenactivated protein kinase proinflammatory pathways [371]. Hydrostatin-SN1 was proposed to be a promising candidate for the development of treatments for acute lung injury [164] and inflammatory bowel diseases [371]. Bioactive peptides were also reported from the giant barrel sponge, Xestospongia testudinaria [373] and rough leather coral, Sarcophyton glaucum [374] KENPVLSLVNGMF derived from X. testudinaria was dosedependently cytotoxic to the human cervical cancer cell line (HeLa), being 3.8-fold stronger than anticancer drug 5-fluorouracil. By contrast, the peptide showed only a marginal 5\% cytotoxicity to Hek293, a non-cancerous, human embryonic kidney cell line [374]. Likewise, AGAPGG, AERQ, and RDTQ identified from S. glaucum were more cytotoxic to HeLa cells than 5-fluorouracil, besides low toxicity to Hek293 cells [374]. Together, the aforementioned findings point to the potential of the four peptides as candidates for future development of anticancer drugs. Antioxidant peptides have been isolated from the by-products of the fish, mollusk, and crustacean processing, e.g., fish scales, fish skin, squid skin, and abalone 
viscera [375]. The ability of such peptides to dampen lipid oxidation and preserve seafood quality during processing and storage points to their potential application as preservatives [375]. Such peptides are also promising candidates in the development of therapeutics, adjunct therapeutics, or nutraceuticals against oxidative stress-related diseases or conditions [376]. Overall, marine peptides, whether derived from non-edible marine organisms or seafood processing by-products, may have potential applications in the discovery of peptide-based therapeutic agents and formulation of nutraceuticals.

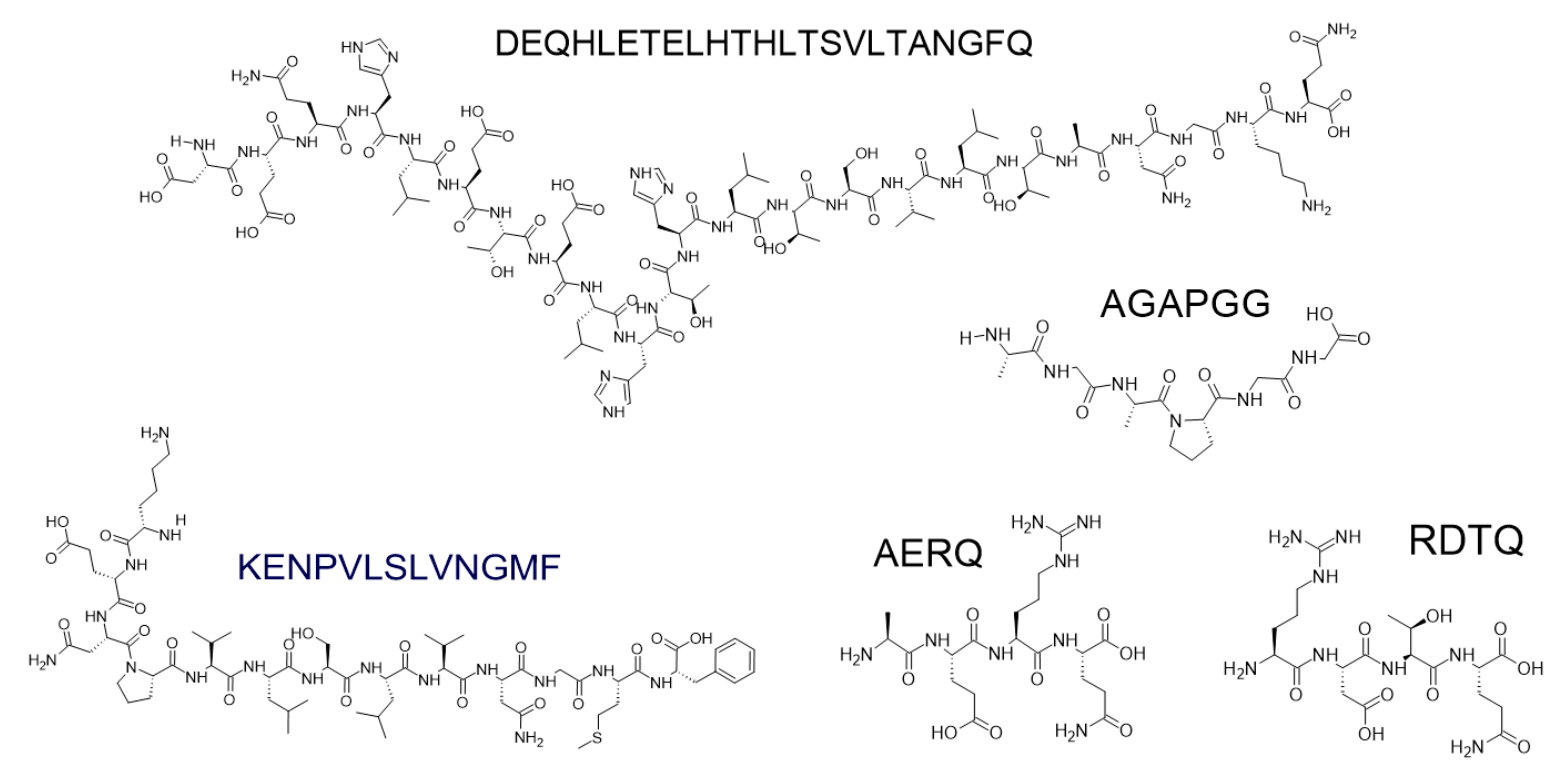

Figure 12. Anti-inflammatory (DEQHLETELHTHLTSVLTANGFQ) and cytotoxic (KENPVLSLVNGMF, AGAPGG, AERQ, and RDTQ) peptides derived from non-edible marine organisms.

\subsection{Peptide-Based Cosmeceuticals}

Biologically active short peptides are important cosmeceuticals, i.e., agents linking cosmetics and drugs. They deliver bio-activity in support of aesthetic effects $[377,378]$. The term "cosmeceutical" was coined in 1984 by Albert Kligman [379]. Peptide-based cosmeceuticals acting against both intrinsic and extrinsic aging and improving the health and appearance of skin are becoming increasingly popular. Bioactive peptides have either pharmaceutical or cosmetic value and open a new avenue in the field of gerocosmetology [380,381]. They are used for collagen stimulation, wound healing, "botox-like" wrinkle smoothing, as well as antioxidative, antimicrobial, and whitening effects [378]. Topical peptides are classified as carriers [copper tripeptide-1 (Cu-GHK), manganese tripeptide-1 (Mn-GHK), signal peptides [palmitoyl hexapeptide-12 (biopeptideELTM, palmitoyl pentapetide-4 (matrixyl), palmitoyl tripeptide-1 (biopeptide CLTM), palmitoyl tripeptide5 (syn-coll), elaidyl-Lys-Phe-Lys-OH (lipospondin), hexapeptide-11 or pentamide-6, tripeptide10 citrulline (decorinyl) and neurotransmiter inhibitors [acetyl hexapeptide-3 (argireline), pentapeptide-3 (vialox), pentapeptide-18 (leuphasyl), tripeptide-3 (syn-ake), acetyl octapeptide1/-3 (sNAP-8) peptides [382]. Moreover, several natural peptides, such as carnosine, keratin, soybean, silk fibroin, and black rice peptides cannot be neglected [383]. These natural peptides as cosmeceutical ingredients fit perfectly into the rules of sustainability due to their high biodegadibility, low toxicity, moderate manufacturing costs, and convenient scale-up production ability [382]. More specifically, the United Nation defined 17 Sustainable Development Goals for the better future of the world, in relation to either people or the environment. In general, the main idea could be defined as "one global goal: good life for all". One of these 17 aims is "good health and well-being" [384]. The forecast for the global cosmeceutical market predicts an increase by $\sim 10 \%$ in the next years. Its significant share will be related to peptide-based products. 


\section{Conclusions and Future Outlook}

Short peptides exhibit a remarkable array of biological functions, which may be used by innovative therapies in almost all branches of medicine. They are synthesized and investigated by research groups spread all over the world. The number of publications and patents in the subject has been growing enormously over the last years. This global review reflects this situation. It is written by scientists from all continents of the world who tried to unveil "fifty shades" of short peptides with the emphasis on biomedical, diagnostic, pharmaceutical, and cosmeceutical applications. In particular, peptides can play either a leading role as drugs or a supporting role in diagnosis, treatment, cell penetration, or targeting, and many more. Peptide-based vaccines are an expected breakthrough in cancer, microbial, or allergen immunotherapies. Natural and synthetic short peptides, including peptidomimetics, find numerous applications in nanotechnology and are thoroughly investigated by structural bio-informatics and supramolecular chemistry. Moreover, the development of comprehensive in silico techniques combined with efficient advanced synthetic methods facilitates the production of peptide based chemical species of almost unlimited applicabilities.

To sum up, short peptides can be a secret of idealized smart therapies.

Author Contributions: The article was written through equal contributions of all authors, from all continents of the globe. V.A. and V.B.: Immune modulation using altered peptide ligands in autoimmune diseases; T.-T.C.: Marine peptides; S.E. and M.A.: Antimicrobial lactoferrin-based peptides as anti-COVID-19; J.M. and K.K. (Konstantinos Kelaidonis): Cyclic peptides and mimetics; R.N. and E.M.S.: Taking peptide aptamers to a new level; K.P.: Cell-penetrating peptides as molecular transporters; O.P.L.: Nutraceuticals; H.P.: Oligopeptides in gene delivery; C.O.P.: Peptides from digestion of proteins; M.P.: Peptide interactions with lipid bilayers using Molecular Dynamics simulations; M.R.: Geometry optimization, conformational analysis; M.S. (Michele Saviano): Costrained aminoacids: a molecular "meccano"; M.S. (Mariusz Skwarczynski) and I.T.: Peptide-based vaccines; Y.T.: Short peptide-based anti-viral agents against SARS-CoV-2; T.Y.: Short difficult peptide synthesis; J.Z. and K.K. (Krzysztof Kaczmarek): Advances in the Synthesis of Short Peptides and Modified Amino Acids; P.Z.: Modelling of short peptides; W.M.W.: supervision, overseeing, survey of the newest scientific literature, checking and correction of the text; J.B.: idea, establishing cooperation with co-authors, writing: Abstract, Introduction, A brief history, Short peptides: definition, Role of short peptides in neurodegenerative treatment, Nanoengineering \& supramolecular approach towards smart short peptide-based therapeutics \& biomaterials, Relevance of short peptides in stem cell research, Peptide-based cosmeceuticals, Advantages vs. disadvantages: SWOT analysis, To overcome shortcomings of peptides: mission (im)possible? Ultra-short peptides: less is more, Conclusions. All authors have read and agreed to the published version of the manuscript.

Funding: This research received no external funding.

Acknowledgments: V.A. and V.B. would like to thank the Institute for Health and Sport for their support. V.B. was supported by a Victoria University Postgraduate Scholarship. J.M. and K.K. (Konstantinos Kelaidonis) would like to thank the General Secretariat for Research and Technology (GSRT) in Greece and Patras Science Park for supporting their research. Y.T. acknowledges the financial supports from National Natural Science Foundation of China $(21772109,21971140)$. T.T.C. would like to acknowledge the Fundamental Research Grant Scheme of the Ministry of Higher Education, Malaysia, and Universiti Tunku Abdul Rahman Research Fund for supporting his bioactive peptide research. W.M.W. The European University Foundation is acknowledged for advising on the legal and social dimension of this study. J.B. thanks Editor Tina Li for the invitation to playing a role of Guest Editor as well as all co-authors of this article for agreeing for her invitations and very nice co-operation. She has privilege of working with distinguished scientists from all over the world. Consequently, this unique global article (and special issue) as well as global adventure, which could be entitled "Around the world in eighty days" (from the first co-author agreement to completion of our article) can be realized. She is also grateful to Wojciech M. Wolf and Andrzej Olczak for "helping hand in need" and Izabela Narkiewicz for polishing the English language.

Conflicts of Interest: The authors declare no conflict of interest. 


\section{Abbreviations}

\begin{tabular}{|c|c|}
\hline A & Acidic \\
\hline $\mathrm{ACE}(\mathrm{I})$ & angiotensin-converting enzyme (inhibitors) \\
\hline AchRs & acetylcholine receptors \\
\hline AIDS & acquired immune deficiency syndrome \\
\hline Alloc & allyloxycarbonyl \\
\hline AMPs & antimicrobial peptides \\
\hline APCs & antigen presenting cells \\
\hline APL & altered peptide ligands \\
\hline ARB & angiotensin receptor blockers \\
\hline B & basic \\
\hline BAP & bioactive peptides \\
\hline BOC & butoxycarbonyl \\
\hline Bzl & benzyl \\
\hline CG & coarse grain \\
\hline COVID-19 & coronavirus disease 2019 \\
\hline CPPs & cell penetrating peptides \\
\hline CSD & Cambridge Structure Database \\
\hline CTL & cytotoxic T lymphocyte \\
\hline $2 \mathrm{D}$ & two-dimensional \\
\hline $3 \mathrm{D}$ & three-dimensional \\
\hline $\mathrm{DH}$ & degree of hydrolysis \\
\hline DKP & diketopiperazines \\
\hline DNA & deoxyribonucleic acid \\
\hline EDTA & ethylenediaminetetraacetic acid \\
\hline FAS & fatty acid synthase \\
\hline FDA & Food and Drug Administration \\
\hline FMOC & fluorenylmethoxycarbonyl \\
\hline GALA & glutamic acid-alanine-leucine-alanine \\
\hline GAS & group A streptococcus \\
\hline GDS & gene delivery system \\
\hline GFR & growth factor receptors \\
\hline HeLa & human cervical cancer cell line \\
\hline HIV & human immunodeficiency virus \\
\hline HMG & high motility group \\
\hline HMGR & 3-hydroxy-3-methylglutaryl CoA reductase \\
\hline HOAt & 1-hydroxy-7-aza-benzotriazole \\
\hline HOBt & 1-hydroxy-benzotriazole \\
\hline HPLC & high performance liquid chromatography \\
\hline IFN & interferon \\
\hline IUPAC & International Union of Pure and Applied Chemistry \\
\hline LDL & low-density lipoprotein \\
\hline LDLR & LDL receptor \\
\hline LF & lactoferrin \\
\hline LPS & lipopolysaccharide \\
\hline LRPs & low density lipoprotein receptors \\
\hline LRs & leptin receptors \\
\hline $\mathrm{MBP}$ & myelin basic protein \\
\hline MD & molecular dynamics \\
\hline MHC & major histocompatibility complex \\
\hline NF & nuclear factor \\
\hline NLSs & nuclear localization signals \\
\hline NPC & nuclear pore complex \\
\hline PDC & pyruvate dehydrogenase complexes \\
\hline PEG & polyethylene glycol \\
\hline PES & potential energy surface \\
\hline PPI & proton-pump inhibitors \\
\hline
\end{tabular}




$\begin{array}{ll}\text { RAS } & \text { renin-angiotensin system } \\ \text { RCSB PDB } & \text { Research Collaboratory for Structural Bioinformatics Protein Data Bank } \\ \text { RGD } & \begin{array}{l}\text { arginine-glycine-aspartic acid } \\ \text { ribonucleic acid }\end{array} \\ \text { RNA } & \text { Severe Acute Respiratory Syndrome Coronavirus } \\ \text { SARS-COV-2 } & \text { solid-phase synthesis } \\ \text { SPPS } & \text { sterol regulatory element-binding protein } 2 \\ \text { SREBP2 } & \text { strengths, weaknesses, opportunities, and threats } \\ \text { SWOT } & \text { tert-butyl } \\ \text { tBu } & \text { trifluoroacetic acid } \\ \text { TFA } & \text { transferrin receptors } \\ \text { TFRs } & \text { trimethyl chitosan } \\ \text { TMC } & \text { tumor necrosis factor alpha } \\ \text { TNF } & \text { tumor necrosis factor receptor 1 } \\ \text { TNFR } & \end{array}$

\section{References}

1. Muheem, A.; Shakeel, F.; Jahangir, M.A.; Anwar, M.; Mallick, N.; Jain, G.K.; Warsi, M.H.; Ahmad, F.J. A review on the strategies for oral delivery of proteins and peptides and their clinical perspectives. Saudi Pharm. J. 2016, 24, 413-428. [CrossRef]

2. Fruton, J.S. Chapter 5-Emil Fischer and Franz Hofmeister. Contrasts in Scientific Style: Research Groups in the Chemical and Biochemical Sciences. Am. Philos. Soc. 1990, 191, 163-165.

3. Mulder, G.J. Sur la composition de quelques substances animales. Bull. Sci. Phys. Nat. Neerl. 1838, 104, 1-192.

4. Hartley, H. Origin of the world protein. Nature 1951, 168, 244. [CrossRef]

5. Hamley, I.W. Introduction to Peptide Science; Wiley: Weinheim, Germany, 2020; ISBN 978-1-119-69817-3.

6. Reynolds, J.A.; Tanford, C. Nature's Robots: A History of Proteins; Oxford University Press: New York, NY, USA, $2003 ;$ p. 15.

7. Vickery, H.B.; Schmidt, C.L. The history of the discovery of the amino acids. Chem. Rev. 1931, 9, 169-318. [CrossRef]

8. Hansen, S. Die Entdeckung der Proteinogenen Aminosauren von 1805 in Paris bis 1935 in Illinois. 2015. Available online: https:/ / www.arginium.de/wp-content/uploads/2015/12/Aminosäuren-Entdeckungseschichte (accessed on 15 June 2016).

9. Vauquelin, L.N.; Robiquet, P.J. The discovery of a new plant principle in Asparagus sativus. Ann. Chim. 1806, 57, 88-93.

10. Anfinsen, C.B.; Edsall, J.T.; Richards, F.M. The formation and stabilization of protein structure. Adv. Protein Chem. 1972, 99, 1-424. [CrossRef]

11. Paal, C. Ueber die Einwirkung von phenyl-i-cyanat auf organische Aminosauren. In Berichte der Deutschen Chemischen Gesellschaft; Wiley Online Library: Berlin, Germany, 1894; pp. 974-979.

12. Harper, D. Amino Online Etymology Dictionary. 2010. Available online: https://www.etymonline.com/ (accessed on 15 January 2021).

13. Chandrudu, S.; Simerska, P.; Toth, I. Chemical methods for peptide and protein production. Molecules 2013, 18, 4373-4388. [CrossRef]

14. Fischer, E.; Fourneau, E. Ueber einige derivate des Glykocolls. Eur. J. Inorg. Chem. 1901, 34, 2868-2877. [CrossRef]

15. Wieland, T.; Bodanszky, M. The World of Peptides; Springer: Berlin/Heidelberg, Germany, 1991.

16. Grant, G.A. Synthetic Peptides: A User's Guide, 2nd ed.; Oxfprd University Press: New York, NY, USA, 2002; pp. 1-9. ISBN 9780195132618.

17. Bojarska, J.; Kaczmarek, K.; Zabrocki, J.; Wolf, W.M. Amino Acids: Molecules of life. Int. J. Nutr. Sci. 2019 , 4, $1035-1037$.

18. Frenkel-Pinter, M.; Samanta, M.; Ashenasy, G.; Leman, L.J. Prebiotic pepitdes: Molecular hibs in the origin of life. Chem. Rev. 2020, 120, 4707-4765. [CrossRef]

19. Muchowska, K.; Moran, J. Peptide synthesis at the origin of life. Science 2020. [CrossRef]

20. Schiller, M.R. The minimotif synthesis hypothesis for the origin of life. J. Transl. Sci. 2016, 2, 289-296. [CrossRef]

21. Greenwald, J.; Kwiatkowski, W.; Riek, R. Peptide amyloids in the origin of life. J. Mol. Biol. 2018, 430, 3735-3750. [CrossRef]

22. IUPAC-IUB Joint Commission on Biochemical Nomenclature (JCBN) Nomenclature and Symbolism for Amino Acids and Peptides. Eur. J. Biochem. 1984, 138, 9-37. [CrossRef]

23. Mirabeau, O. Searching for Novel Peptide Hormones in the Human Genome. Life Sciences [q-bio]. Ph.D. Thesis, Université Montpellier II-Sciences et Techniques du Languedoc, Montpellier, France, 2008.

24. Su, M.; Ling, Y.; Yu, J.; Wu, J.; Xiao, J. Small proteins: Untapped area of potential biological importance. Front Genet. 2013, 4, 286-295. [CrossRef]

25. Schmidt, A.; Teeter, M.; Weckert, E.; Lamzin, V.S. Crystal structure of small protein crambin at 0.48 A resolution. Acta Cryst. F 2011, 67, 424-428. [CrossRef]

26. Patel, V.; Asatryan, B.; Siripanthong, B.; Munroe, P.B.; Tiku-Owens, A.; Lopes, L.R.; Khanji, M.Y.; Protonotarios, A.; Santangeli, P.; Muser, D.; et al. State of the art review on genetics and precision medicine in arrhythmogenic cardiomyopathy. Int. J. Mol. Sci. 2020, 21, 6615-6662. [CrossRef]

27. Habault, J.; Poyet, J.L. Recent advances in cell penetrating peptide-based anticancer therapies. Molecules 2019, $24,927-944$. [CrossRef] 
28. Derakhshankhah, H.; Jafari, S. Cell penetrating peptides: A concise review with emphasis on biomedical applications. Biomed. Pharmacother. 2018, 108, 1090-1096. [CrossRef]

29. Fisher, F.; Pavlenko, K.; Vlasov, A.; Ramenskaya, G. Peptide-based therapeutics for oncology. Pharm. Med. 2019, 33, 9-20. [CrossRef]

30. Pavan, S.; Berti, F. Short peptides as biosensors transducers. Anal. Bioanal. Chem. 2012, 402, 3055-3070. [CrossRef] [PubMed]

31. E-kobon, T.; Thongararm, P.; Roytrakul, S.; Meesuk, L.; Chumnanpuen, P. Prediction of anticancer peptides against MCF-7 breast cancer cells from the peptidomes of Achatina fulica mucus fractions. Comp. Struct. Biotechnol. J. 2016, 4, 49-57. [CrossRef]

32. Horsley, J.R.; Jovcevski, B.; Wegener, K.L.; Yu, J.; Pukala, T.L.; Abell, A.D. Rationally designed peptide-based inhibitor of A-beta42 fibril formation and toxicity: A potential therapeutic strategy for Alzheimer's disease. Biochem. J. 2020, 477, 2039-2054. [CrossRef]

33. Baig, M.H.; Ahmad, K.; Rabbani, G.; Choi, I. Use of peptides for the management of Alzheimer's disease: Diagnosis and inhibition. Front. Aging Neurosci. 2018, 10. [CrossRef]

34. Hamley, I.W. Small bioactive peptides for biomaterials design and therapeutics. Chem. Rev. 2017, 117, 14015-14041. [CrossRef] [PubMed]

35. Hauser, C.A.E.; Deng, R.; Mishra, A.; Loo, Y.; Khoe, U.; Zhuang, F.; Cheong, D.W.; Accardo, A.; Sullivan, M.B.; Riekel, C.; et al. Natural tri- to hexapeptides self-assemble in water to amyloid beta-type fiber aggregates by unexpected alpha-helical intermediate structures. Proc. Natl. Acad. Sci. USA 2011, 108, 1361-1366. [CrossRef]

36. Seow, W.Y.; Hauser, C.A.E. Short to ultrashort peptide hydrogels for biomedical uses. Mater. Today 2014, 17, 381-388. [CrossRef]

37. Makovitzki, A.; Avrahami, D.; Shai, Y. Ultrashort antibacterial and antifungal lipopetides. Proc. Natl. Acad. Sci. USA 2006, 103, 15997-16002. [CrossRef]

38. Ni, M.; Zhuo, S. Applications of self-assembling ultrashort peptides in bionanotechnology. RSC Adv. 2019, 9, 844-852. [CrossRef]

39. Fosgerau, K.; Hoffmann, T. Peptide therapeutics: Current status and future directions. Drug Discov. Today 2015, 20, 122-128. [CrossRef]

40. Soudy, R.; Kimura, R.; Patel, A.; Fu, W.; Kaur, K.; Westaway, D.; Yang, J.; Jhamandas, J. Short amylin receptor antagonist peptides improve memory deficits in Alzheimer's disease mouse model. Sci. Rep. 2019, 9, 10942-10953. [CrossRef]

41. Morimoto, B.H. Therapeutic peptides for CNS indications: Progress and challenges. Bioorganic Med. Chem. 2018, 26, 2859-2862. [CrossRef]

42. Haggag, Y.A.; Donia, A.A.; Osman, M.A.; El-Gizawy, S.A. Peptides as drug candidates: Limitations and recent development perspectives. Biomed. J. Sci. Tech. Res. 2018, 8, 6659-6663. [CrossRef]

43. Henninot, A.; Collins, J.C.; Nuss, J.M. The current state of peptide drug discovey: Back to the future? J. Med. Chem. 2018, 61, 1382-1414. [CrossRef]

44. Lee, A.C.; Harris, J.L.; Khanna, K.K.; Hong, J.H. A Comprehensive Review on Current Advances in Peptide Drug Development and Design. Int. J. Mol. Sci. 2019, 20, 2383-2404. [CrossRef]

45. Qian, Z.; Liu, T.; Liu, Y.-Y.; Briesewitz, R.; Barrios, A.M.; Jhiang, S.M. Efficient delivery of cyclic peptides into mammalian cells with short sequence motifs. ACS Chem. Biol. 2013, 8, 423-431. [CrossRef]

46. Taylor, R.E.; Zahid, M. Cell penetrating peptides, novel vectors for gene therapy. Pharmaceutics 2020, 12, 225-246. [CrossRef]

47. Ellert-Miklaszewska, A.; Poleszak, K.; Kaminska, B. Short peptides interfering with signaling pathways as new therapeutic tools for cancer treatments. Future Med. Chem. 2017, 9, 199-221. [CrossRef]

48. Lenci, E.; Trabocchi, A. Peptidomimetic toolbox for drug discovery. Chem. Soc. Rev. 2020, 49, 3262-3277. [CrossRef]

49. Zhang, R.; Leeper, C.N.; Wang, X.; White, T.A.; Ulery, B.D. Immunomodulatory vasoactive intestinal peptide amphiphile micelles. Biomater. Sci. 2018, 6, 1717-1722. [CrossRef] [PubMed]

50. Kalafatovic, D.; Giralt, E. Cell-penetrating peptides: Design strategies beyond primary structure and amphipathicity. Molecules 2017, 22, 1929. [CrossRef] [PubMed]

51. Kong, X.D.; Moriya, J.; Carle, V.; Pojer, F.; Abriata, L.A.; Deyle, K.; Heinis, C. De novo development of proteolytically resistant therapeutic peptides for oral administration. Nat. Biomed. Eng. 2020, 4, 560-571. [CrossRef] [PubMed]

52. Brayden, D.J. Evolving peptides for oral intake. Nat. Biomed. Eng. 2020, 4, 487-488. [CrossRef] [PubMed]

53. Brown, T.D.; Whitehead, K.A.; Mitragotri, S. Materials for oral delivery of proteins and peptides. Nat. Rev. Mater. 2020, 5, 127-148. [CrossRef]

54. Benedetti, E.; Pedone, C.; Saviano, M. Structure-Activity Relationships in Peptides: From Modelling to Rational Drug Design. Front. Drug Des. Discov. 2007, 3, 2007-2539.

55. Di Blasio, B.; Pavone, V.; Saviano, M.; Lombardi, A.; Nastri, F.; Pedone, C.; Benedetti, E.; Crisma, M.; Anzolin, M.; Toniolo, C. Structural Characterization of the $\alpha$-bend Ribbon Spiral: Crystallographic Analysis of two long (L-Pro-Aib)n Sequential Peptides. J. Am. Chem. Soc. 1992, 114, 6273-6278. [CrossRef]

56. Pavone, V.; Lombardi, A.; Saviano, M.; Di Blasio, B.; Nastri, F.; Fattorusso, R.; Zaccaro, L.; Maglio, O.; Yamada, T.; Omote, Y.; et al. Mixed conformation in $C^{\alpha, \alpha}$-disubstituted tripeptides: X-ray Crystal structure of Z-Aib-Dph-Gly-OMe and Bz-Dph-Dph-GlyOme. Biopolymers 1994, 34, 1595-1604. [CrossRef]

57. Moretto, V.; Formaggio, F.; Crisma, M.; Bonora, G.M.; Toniolo, C.; Benedetti, E.; Santini, A.; Saviano, M.; Di Blasio, B.; Pedone, C. Preferred Conformation of Peptides Rich in $\mathrm{Ac}_{8} \mathrm{c}$, a Medium-ring Alicyclic $\mathrm{C}^{\alpha, \alpha}$-disubstituted Glycine. J. Pep. Sci. 1996, 2, 14-27.

58. Benedetti, E.; Iacovino, R.; Saviano, M. The Use of Uncoded $\alpha$-Amino Acidds Residues in Drug Design in Proceedings of 24th Crystallographic Course; Codding, P.W., Ed.; ESCOM: Leiden, The Netherlands, 1998; pp. 103-112. 
59. Toniolo, C.; Crisma, M.; Formaggio, F.; Benedetti, E.; Santini, A.; Iacovino, R.; Saviano, M.; Di Blasio, B.; Pedone, C.; Kamphuis, J. Preferred conformation of Peptides Rich in Alicyclic $C^{\alpha, \alpha}$ disubstituted Glycine. Biopolymers 1996, 40, 519-522. [CrossRef]

60. Gatos, M.; Formaggio, F.; Crisma, M.; Valle, G.; Toniolo, C.; Bonora, G.M.; Saviano, M.; Iacovino, R.; Menchise, V.; Galdiero, S.; et al. Conformational Characterization of Peptides Rich in the Cycloaliphatic $C^{\alpha, \alpha}$-disubstituted Glycine 1-Amino cyclononane-1carboxylic Acid. J. Pept. Sci. 1997, 3, 367-382. [CrossRef]

61. Benedetti, E.; Di Blasio, B.; Iacovino, R.; Menchise, V.; Saviano, M.; Pedone, C.; Bonora, G.M.; Ettorre, A.; Graci, L.; Formaggio, F; i et al. Conformation Restriction through $C_{i} \leftrightarrow C_{i}$ cyclication: 1-amminocycloheptane-1-carboxylic acid (Ac7c). J. Chem. Soc. Perkin 2 1997, 2, 2023-2032. [CrossRef]

62. Pavone, V.; Lombardi, A.; Saviano, M.; Nastri, F.; Zaccaro, L.; Maglio, O.; Pedone, C.; Omote, Y.; Yamanaka, Y.; Yamada, T. Conformational Behaviour of C-Diphenyl Glycine. Folded Versus Extended Structures in D g Containng Tripeptides. J. Pept. Sci. 1998, 4, 21-32. [CrossRef]

63. Saviano, M.; Iacovino, R.; Menchise, V.; Benedetti, E.; Bonora, G.M.; Gatos, M.; Graci, L.; Formaggio, F.; Crisma, M.; Toniolo, C. Conformational Restriction through $C_{i} \leftrightarrow C_{i}$ Cyclization: $A_{12} c$, the Largest Cycloaliphatic $C^{\alpha, \alpha}$-Disubstituted Glycine Known. Biopolymers 2000, 53, 200-212. [CrossRef]

64. Moretto, A.; Formaggio, F.; Crisma, M.; Toniolo, C.; Saviano, M.; Iacovino, R.; Vitale, R.M.; Benedetti, E. Ac10c: A medium-ring, cycloaliphatic $\mathrm{C}$-disubstituted glycine. Incorporation into model peptides and preferred conformation. J. Pept. Res. 2001, 57, 307-315. [CrossRef]

65. Formaggio, F.; Crisma, M.; Toniolo, C.; Broxterman, Q.B.; Kaptein, B.; Corbier, C.; Saviano, M.; Palladino, P.; Benedetti, E. C-methyl, C-n-propylglycine homo-oligomers. Macromolecules 2003, 36, 8164-8170. [CrossRef]

66. Crisma, M.; Saviano, M.; Moretto, A.; Broxterman, Q.B.; Kaptein, B.; Toniolo, C. Peptide $\alpha / 3_{10}$-helix dimorphism in the crystal state. J. Am. Chem. Soc. 2007, 129, 15471-15473. [CrossRef]

67. Saviano, M.; Aida, M.; Corongiu, G. Molecular Dynamics Simulation in vacuo and in solution of Cyclolinopeptide A: A Conformational Study. Biopolymers 1991, 31, 1017-1024. [CrossRef]

68. Di Blasio, B.; Rossi, F.; Benedetti, E.; Pavone, V.; Saviano, M.; Pedone, C.; Zanotti, G.; Tancredi, T. Bioactive Peptide: X-Ray and NMR Conformational Study of [Aib ${ }^{5,6}$-Dala ${ }^{8}$ ] Cyclolinopeptide A. J. Am. Chem. Soc. 1992, 114, 8277-8283. [CrossRef]

69. Saviano, M.; Rossi, F.; Di Blasio, B.; Pavone, V.; Pedone, C. Molecular Dynamics Simulation in vacuo and in solution of [Aib ${ }^{5,6}$-Dala ${ }^{8}$ ] Cyclolinopeptide A. A Conformational and Comparative Study. J. Biomol. Struct. Dyn. 1992, 9, 1045-1060. [CrossRef]

70. Rossi, F.; Saviano, M.; Di Talia, P.; Di Blasio, B.; Pedone, C.; Zanotti, G.; Mosca, M.; Saviano, G.; Tancredi, T.; Ziegler, K.; et al. Solution and Solid State Structure of an Aib-Containing Cyclodecapeptide Inhibiting the Cholate Uptake in Hepatocytes. Biopolymers 1996, 40, 465-478. [CrossRef]

71. Becker, E.L.; Freer, R.J.; Toniolo, C.; Balaram, P. Membrane Receptors and Cellular Regulation; Czech, M.P., Kahn, C.R., Eds.; Liss: New York, NY, USA, 1985; pp. 129-134.

72. Gatto, E.; Bocchinfuso, G.; Palleschi, A.; Oncea, S.; De Zotti, M.; Formaggio, F.; Toniolo, C.; Venanzi, M. 3D Structure, Dynamics, and Activity of Synthetic Analog of the Peptaibiotic Trichodecenin I. Chem. Biodivers. 2013, 10, 887-903. [CrossRef]

73. Venanzi, M.; Gatto, E.; Formaggio, F.; Toniolo, C. The importance of being Aib. Aggregation and self-assembly studies on conformationally constrained oligopeptides. J. Pep. Sci. 2017, 23, 104-116. [CrossRef] [PubMed]

74. De Zotti, M.; Muzzi, B.; Gatto, E.; Di Napoli, B.; Mazzuca, C.; Palleschi, A.; Placidi, E.; Formaggio, F.; Toniolo, C.; Venanzi, M. Tuning the Morphology of Nanostructured Peptide Films by the Introduction of a Secondary Structure Conformational Constraint: A Case Study of Hierarchical Self-Assembly. J. Phys. Chem. B. 2018, 122, 6305-6313. [CrossRef]

75. Moore, G.; Smith, J.; Baylis, B.; Matsoukas, J. Design and pharmacology of peptide mimetics. Adv. Pharmacol. 1995, 33, 91-141.

76. Katsara, M.; Deraos, G.; Tselios, T.; Matsoukas, M.; Friligou, I.; Matsoukas, J.; Apostolopoulos, V. Design and Synthesis of a Cyclic Double Mutant Peptide (cyclo(87-99)[ $\left[\mathrm{A}^{91}, \mathrm{~A}^{96}\right] \mathrm{MBP}_{87-99}$ ) Induces Altered Responses in Mice after Conjugation to Mannan: Implications in the Immunotherapy of Multiple Sclerosis. J. Med. Chem. 2009, 52, 214-218. [CrossRef] [PubMed]

77. Katsara, M.; Tselios, T.; Deraos, S.; Deraos, G.; Matsoukas, M.; Lazoura, E.; Matsoukas, J.; Apostolopoulos, V. Round and round we go: Cyclic peptides in disease. Curr. Med. Chem. 2006, 13, 2221-2232. [PubMed]

78. Matsoukas, J.; Hondrelis, J.; Agelis, G.; Barlos, K.; Gatos, D.; Ganter, R.; Moore, D.; Moore, G. Novel synthesis of cyclic amide-linked analogs of angiotensins II and III. J. Med. Chem. 1994, 37, 2958-2969. [CrossRef]

79. Matsoukas, J.; Hondrelis, J.; Keramida, M.; Mavromoustakos, T.; Makriyannis, A.; Yamdagni, R.; Wu, Q.; Moore, G.J. Role of the NH2-terminal domain of angiotensin II (ANG II) and [Sar1] angiotensin II on conformation and activity. NMR evidence for aromatic ring clustering and peptide backbone folding compared with [des-1,2,3] angiotensin II. J. Med. Chem. 1994, 269, 5303-5312.

80. Matsoukas, J.; Polevaya, L.; Ancans, J.; Mavromoustakos, T.; Kolocouris, A.; Roumelioti, P.; Vlahakos, D.; Yamdagni, R.; Wu, Q.; Moore, G. The design and synthesis of a potent angiotensin II cyclic analogue confirms the ring cluster receptor conformation of the hormone angiotensin II. Bioorganic Med. Chem. 2000, 8, 1-10. [CrossRef]

81. Polevaya, L.; Mavromoustakos, T.; Zoumboulakis, P.; Grdadolnik, S.; Roumelioti, P.; Giatas, N.; Mutule, I.; Keivish, T.; Vlahakos, D.; Iliodromitis, E.; et al. Synthesis and study of a cyclic angiotensin II antagonist analogue reveals the role of $\pi^{*}-\pi^{*}$ interactions in the C-terminal aromatic residue for agonist activity and its structure resemblance with $\mathrm{AT}_{1}$ non-peptide antagonists. Bioorganic Med. Chem. 2001, 9, 1639-1647. [CrossRef] 
82. Apostolopoulos, V.; Rostami, A.; Matsoukas, J. The Long Road of Immunotherapeutics against Multiple Sclerosis. Brain Sci. 2020, 10, 288-295. [CrossRef] [PubMed]

83. Keramida, M.; Tselios, T.; Mantzourani, E.; Papazisis, K.; Mavromoustakos, T.; Klaussen, C.; Agelis, G.; Deraos, S.; Friligou, I.; Habibi, H.; et al. Design, Synthesis, and Molecular Modeling of a Novel Amide-Linked Cyclic GnRH Analogue Cyclo(4-9)[Lys ${ }^{4}$,D$\operatorname{Trp}^{6}, \mathrm{Glu}^{9}$ ] GnRH: Stimulation of Gonadotropin Gene Expression. J. Med. Chem. 2006, 49, 105-110. [CrossRef] [PubMed]

84. Alexopoulos, K.; Alexopoulos, K.; Fatseas, P.; Melissari, E.; Vlahakos, D.; Smith, J.; Mavromoustakos, T.; Saifeddine, M.; Moore, G.; Hollenberg, M.; et al. Design and synthesis of thrombin receptor-derived nonpeptide mimetics utilizing a piperazine scaffold. Bioorganic Med. Chem. 1999, 7, 1033-1041. [CrossRef]

85. Tseveleki, V.; Tselios, T.; Kanistras, I.; Koutsoni, O.; Karamita, M.; Vamvakas, S.; Apostolopoulos, V.; Dotsika, E.; Matsoukas, J.; Lassmann, H.; et al. Mannan-conjugated myelin peptides prime non-pathogenic Th1 and Th17 cells and ameliorate experimental autoimmune encephalomyelitis. Exp. Neurol. 2015, 267, 254-267. [CrossRef] [PubMed]

86. Moore, G.; Matsoukas, J. Angiotensin as a model for hormone-receptor interactions. Biosci. Rep. 1985, 5, 407-416. [CrossRef] [PubMed]

87. Mavromoustakos, T.; Kolocouris, A.; Zervou, M.; Roumelioti, P.; Matsoukas, J.; Weisemann, R. An Effort to Understand the Molecular Basis of Hypertension through the Study of Conformational Analysis of Losartan and Sarmesin Using a Combination of Nuclear Magnetic Resonance Spectroscopy and Theoretical Calculations. J. Med. Chem. 1999, 42, 1714-1722. [CrossRef]

88. Matsoukas, J.; Agelis, G.; Hondrelis, J.; Yamdagni, R.; Wu, Q.; Gantar, R.; Moore, D.; Moore, G.J.; Smith, J.R. Synthesis and biological activities of angiotensin II, sarilesin, and sarmesin analogs containing Aze or Pip at position 7. J. Med. Chem. 1993, 36, 904-911. [CrossRef]

89. Matsoukas, J.; Agelis, G.; Wahhab, A.; Hondrelis, J.; Panagiotopoulos, D.; Yamdagni, R.; Wu, Q.; Mavromoustakos, T.; Maia, H. Differences in backbone structure between angiotensin II agonists and type I antagonists. J. Med. Chem. 1995, 38, 4660-4669. [CrossRef]

90. Turner, R.; Moore, G.; Matsoukas, J. Fluorescence properties of angiotensin II analogues in receptor-simulating environments: Relationship between tyrosinate fluorescence lifetime and biological activity. Biochim. Biophys. Acta (BBA) Biomembr. 1991, 1065, 21-28. [CrossRef]

91. Agelis, G.; Resvani, A.; Koukoulitsa, C.; Tumova, T.; Slaninova, J.; Kalavrizioti, D.; Spyradaki, K.; Afantitis, A.; Melagraki, G.; Siafaka, A.; et al. Rational design, efficient synthesis and biological evaluation of N,N-symmetrically bis-submituted butylimidazole analogs as a new class potent Angiotensin II receptor blockers. Eur. J. Med. Chem. 2013, 62, 352-370. [CrossRef] [PubMed]

92. Agelis, G.; Kelaidonis, K.; Resvani, A.; Kalavrizioti, D.; Androutsou, M.E.; Plotas, P.; Vlahakos, D.; Koukoulitsa, C.; Tselios, T.; Mavromoustakos, T.; et al. Facile and efficient syntheses of a series of N-benzyl and N-biphenylmethyl substituted imidazole derivatives based on (E)-urocanic acid, as angiotensin II AT1 receptor blockers. Molecules 2013, 18, 7510-7532. [CrossRef] [PubMed]

93. Zhang, P.; Zhu, L.; Cai, J.; Lei, F.; Qin, J.J.; Xie, J.; Liu, Y.M.; Zhao, Y.C.; Huang, X.; Lin, L.; et al. Association of inpatient use of angiotensin converting enzyme inhibitors and angiotensin II receptor blockers with mortality among patients with hypertension hospitalized with Covid-19. Circ. Res. 2020, 126, 1671-1681. [CrossRef] [PubMed]

94. Qaradakhi, T.; Gadanec, L.; Matsoukas, J.; Apostolopoulos, V.; Zulli, A. Could DIZE be the answer to Covid 19? Maturitas 2020, 140, 83-84. [CrossRef] [PubMed]

95. Chan, K.H.; Xue, B.; Robinson, R.C.; Hauser, C.A.E. Systematic moiety variations of ultrashort peptides produce profound effects on self-assembly, nanostructure formation, hydrogelation, and phase transition. Sci. Rep. 2017, 7, 12897-12908. [CrossRef]

96. Ni, M. Ultrashort peptides: Minimum number in amino acid residues, maximum number in bioapplications. Revistabionatura 2019, 4, 763-764. [CrossRef]

97. Dadhwal, S.; Fairhall, J.S.; Goswami, S.K.; Hook, S.; Gamble, A.B. Alkene-azide 1,3-dipolar cycloaddition as a trigger for ultrashort peptide hydrogel dissolution. Chem. Asian J. 2019, 14, 1143-1150. [CrossRef]

98. Makam, P.; Gazit, E. Minimalistic peptide supramolecular co-assembly: Expanding the conformational space for nanotechnology. Chem. Soc. Rev. 2018, 47, 3406-3420. [CrossRef]

99. Kurbasic, I.; Parisi, E.; Garcia, A.M.; Marchesan, S. Self-assembling, ultrashort peptide gels as antimicrobial biomaterials. Curr. Top. Med. Chem. 2020, 20, 1300-1309. [CrossRef]

100. Yadav, N.; Chauhan, M.K.; Chauhan, V.S. Short to ultrashort peptide-based hydrogels as a platform for biomedical applications Biomater. Sci. 2020, 8, 84-100. [CrossRef]

101. Ni, M.; Tresset, G.; Iliescu, C.; Hauser, A.E. Ultrashort peptide theranostic nanoparticles by microfluide-assisted rapid solvent exchange. IEE Trans. Nanobiosci. 2020, 19, 627-632. [CrossRef] [PubMed]

102. Agarwal, G.; Gabrani, R. Antiviral peptides: Identification and validation. Int. J. Pept. Res. Ther. 2020, 18, 1-20. [CrossRef] [PubMed]

103. Subbarao, N.K.; Parente, R.A.; Szoka, F.C.; Nadasdi, L.; Pongracz, K. The pH-dependent bilayer destabilization by an amphipathic peptide. Biochemistry 1987, 26, 2964-2972. [CrossRef] [PubMed]

104. Nygren, P.A. Alternative binding proteins: Affibody binding proteins developed from a small three-helix bundle scaffold. FEBS J. 2008, 275, 2668-2676. [CrossRef] 
105. Kim, H.J.; Antel, J.P.; Duquette, P.; Alleva, D.G.; Conlon, P.J.; Bar-Or, A. Persistence of immune responses to altered and native myelin antigens in patients with multiple sclerosis treated with altered peptide ligand. Clin. Immunol. 2002, 104, 105-114. [CrossRef]

106. Ji, W.; Zhang, C.; Ji, H. Purification, identification and molecular mechanism of two dipeptidyl peptidase IV (DPP-IV) inhibitory peptides from Antarctic krill (Euphausia superba) protein hydrolysate. J. Chromatogr. B Anal. Technol. Biomed. Life Sci. 2017, 1064, 56-61. [CrossRef]

107. Martins, M.B.; Carvalho, I. Diketopiperazines: Biological activity and synthesis. Tetrahedron 2007, 63, 9923-9932. [CrossRef]

108. Feni, L.; Jutten, L.; Parente, S.; Piarulli, U.; Neundorf, I.; Dia, D. Cell-penetrating peptides containing 2,5-DKP scaffolds as shuttles for anti-cancer drugs: Conformational studies and biological activities. Chem. Commun. 2020, 56, 5685-5688. [CrossRef]

109. Sun, S.J.; Liu, Y.C.; Weng, C.H.; Sun, S.W.; Li, F.; Li, H.; Zhu, H. Cyclic dipeptides mediating quorum sensing and their bilogical effects in Hypsizygus Marmoreus. Biomolecules 2020, 10, 298-311. [CrossRef]

110. Wang, Y.; Wang, P.; Ma, H.; Zhu, W. Developments around the bioactive diketopiperazines: A patent review. Expert Opin. Ther. Patents. 2013, 32, 1415-1433. [CrossRef]

111. Borthwick, A.D. 2,5-Diketopiperazines: Synthesis, reactions, medicinal chemistry, and bioactive natural products. Chem. Rev. 2012, 112, 3641-3716. [CrossRef]

112. Bojarska, J.; Wolf, W.M. Ultra short cyclo-peptides as bio-inspired therapeutics: Proline based 2,5-diketopiperazines (DKP). In Proceedings of the 1st International Electronic Conference on Biomolecules: Natural and Bio-Inspired Therapeutics for Human Diseases, online. 1-13 December 2020. Available online: https:/ /www.mdpi.com/journal/biomolecules/events/12176 (accessed on 15 January 2021).

113. Bojarska, J.; Maniukiewicz, W.; Sieron, L.; Remko, M. An orthorhombic polymorph of a cyclization product of perindopril. Acta Cryst. C 2013, 69, 630-633. [CrossRef] [PubMed]

114. Bojarska, J.; Maniukiewicz, W.; Główka, M.L.; Siero'n, L.; Remko, M. Crystal structure of perindopril cyclization product. J. Chil. Chem. Soc. 2013, 58, 1530-1532. [CrossRef]

115. Remko, M.; Bojarska, J.; Jezko, L.; Olczak, A.; Maniukiewicz, W. Molecular structure of antihypertensive drug perindopril, its active metabolite perindoprilat and impurity F. J. Mol. Struct. 2013, 1036, 292-297. [CrossRef]

116. Bojarska, J.; Remko, M.; Wojciechowski, J.; Madura, I.; Kaczmarek, K.; Zabrocki, J.; Zimecki, M.; Wolf, W.M. Cyclic tetrapeptides as promising scaffold for innovative therapeutic agents: Synthesis, crystallographic, biological and in silico studies. Zeitschrift fur Kristallographie. 2020, 40.

117. Bojarska, J.; Maniukiewicz, W.; Sieron, L.; Kopczacki, P.; Walczynski, K.; Remko, M. Perindoprilat monohydrate. Acta Cryst. C 2012, 68, o443-o446. [CrossRef]

118. Bojarska, J.; Maniukiewicz, W.; Sieron, L.; Fruzinski, A.; Kopczacki, P.; Walczynski, K.; Remko, M. Novel pseudopolymorph of the active metabolite of perindopril. Acta Cryst. C 2012, 68, o341-o343. [CrossRef]

119. Bojarska, J.; Maniukiewicz, W.; Fruziński, L.; Sieron, L.; Remko, M. Captopril and its dimer captopril disulfide: Comparative structural and conformational studies. Acta Cryst. C 2015, 71, 199-203. [CrossRef]

120. Remko, M.; Bojarska, J.; Jezko, J.; Sieron, L.; Olczak, A.; Maniukiewicz, W. Crystal and molecular structure of perindopril erbumine salt. J. Mol. Struct. 2011, 997, 103-109. [CrossRef]

121. Remko, M.; Bojarska, J.; Remkova, A.; Maniukiewicz, W. Molecular structure and acidity of captopril, zofenopril and their metabolites captopril disulfide and zofenoprilat. Comput. Theor. Chem. 2015, 1062, 50-55. [CrossRef]

122. Zhao, K.; Xing, R.; Yan, X. Cyclic dipeptides: Biological activities and self-assembled materials. Pept. Sci. 2020, e24202. [CrossRef]

123. Bojarska, J.; Remko, M.; Breza, M.; Madura, I.; Fruziński, A.; Wolf, W.M. A Proline-Based Tectons and Supramolecular Synthons for Drug Design 2.0: A Case Study of ACEI. Pharm. Des. Enzym. Inhib. Potential Drugs 2020, 13, 338. [CrossRef]

124. Ying, J.; Lin, R.; Xu, P.; Wu, Y.; Liu, Y.; Zhao, Y. Prebiotic formation of cyclic dipeptides under potentially early Earth conditions. Sci. Rep. 2018, 8, 936-944. [CrossRef] [PubMed]

125. Burley, S.K.; Berman, H.M. RCSB Protein Data Bank: Biological macromolecular structures enabling researchand education in fundamental biology, biomedicine, biotechnology and energy. Nucleic Acids Res. 2019, 47, D464-D474. [CrossRef]

126. Levin, A.; Hakala, T.; Schnaider, L.; Lopes Bernardes, G.; Gazit, E.; Knowles, T. Biomimetic peptide self-assembly for functional materials. Nat. Rev. Chem. 2020, 4, 615-634. [CrossRef]

127. Bojarska, J.; Kaczmarek, K.; Zabrocki, J.; Wolf, W.M. Supramolecular Chemistry of short peptides and modified amino acids. In Advances in Organic Synthesis; Bentham Science Publisher, Ltd.: Sharjah, UAE, 2018; Chapter 12; Volume 11, pp. 43-107. [CrossRef]

128. Bojarska, J.; Remko, M.; Wojciechowski, J.; Madura, I.; Kaczmarek, K.; Olczak, A.; Zabrocki, J.; Wolf, W.M. Supramolecular synthon polymorphism in modified amino acids. Structural, conformational and energy landscapes of N-benzoyl-2' -hydroxy-3methylisovaline. J. Mol. Struct. 2019, 1190, 11-22. [CrossRef]

129. Bojarska, J.; Kaczmarek, K.; Zabrocki, J.; Wolf, W.M. Supramolecular synthons as related to cooperativity in biocomplexes: Towards design and development of oligopeptide-based modern drugs and cosmeceuticals. Novel Approaches Drug Des. Dev. 2019, 5, 23-25. [CrossRef]

130. Bojarska, J.; Zabrocki, J.; Kaczmarek, K.; Remko, M.; Wolf, W.M. New synthons in supramolecular chemistry of short biologically active peptides. Acta Cryst. A 2019, 75, e588. [CrossRef] 
131. Bojarska, J.; Remko, M.; Breza, M.; Madura, I.; Kaczmarek, K.; Zabrocki, J.; Wolf, W.M. A Supramolecular Approach to Structurebased Design with a Focus on Synthons Hierarchy in Ornithine-derived Ligands: Review, Synthesis, Experimental and in silico Studies. Mol. Struct. Based Des. Biol. Act. Compd. 2020, 25, 1135-1162. [CrossRef]

132. Bojarska, J.; Remko, M.; Madura, I.; Kaczmarek, K.; Zabrocki, J.; Wolf, W.M. Synthesis, experimental and in silico studies of $\mathrm{N}$-fluorenylmethoxycarbonyl-O-tert-butyl-N-methyltyrosine, coupled with CSD data: A survey of interactions in the crystal structures of Fmoc-amino acids. Acta Cryst. C 2020, 76, 328-345. [CrossRef]

133. Zhu, J.; Cifuentes, H.; Reynolds, J.; Lamba, D.A. Immunosupression via loss of IL2r-gamma enhances long-term functional integration of hESC-derived photoreceptors in the mouse retina. Cell Stem Cell 2017, 20, 374-384. [CrossRef] [PubMed]

134. Zhu, H.; Wang, H.; Shi, B.; Shangguan, L.; Tong, W.; Yu, G. Supramolecular peptide constructed by molecular Lego allowing programmable self-assembly for photodynamic therapy. Nat. Commun. 2019, 10, 24120-24130.

135. Glossop, H.D.; Heruka De Zoysa, G.; Hemar, Y.; Cardoso, P.; Wang, K.; Lu, J.; Valery, C.; Sarojini, V. Battacin-inspired ultrashort peptides: Nanostructure analysis and antimicronial activity. Biomacromolecules 2019, 20, 2515-2529. [CrossRef] [PubMed]

136. Chan, K.H.; Lee, W.H.; Ni, M.; Loo, Y.; Hauser, C.A.E. C-terminal residue of ultrashort peptides impacts on molecular selfassembly, hydrogelation, and interaction with small-molecule drugs. Sci. Rep. 2018, 8, 17127-17141. [CrossRef]

137. Gessner, I.; Neundorf, I. Nanoparticles modified with cell-penetrating peptides: Conjugation mechanisms, physicochemical properties, and application in cancer diagnosis and therapy. Int. J. Mol. Sci. 2020, 21, 2536-2557. [CrossRef]

138. Li, S.; Zou, Q.; Li, Y.; Yuan, C.; Xing, R.; Yan, X. Smart peptide-based supramolecular photodynamic metallo-nanodrugs designed by multicomponent coordination self-assembly. JACS 2018, 140, 10794-10802. [CrossRef]

139. Li, S.; Zou, Q.; Xing, R.; Govindaraju, T.; Fakhrullin, R.; Yan, X. Peptide-modulated self-assembly as a versatile strategy for tumor supramolecular nanotheranostics. Theranostics 2019, 9, 3249-3261. [CrossRef]

140. Kaczmarek, K.; Wojciechowski, J.; Wolf, W.M. (2S,4R)-4-ammonio-5-oxopyrrolidine-2-carboxylate. Acta Cryst. E 2010, 66, 831-838. [CrossRef] [PubMed]

141. Mitchell, A.R. Bruce Merrifield and solid-phase peptide synthesis: A historical assessment. Biopolymers 2008, 90, 175-184. [CrossRef]

142. Subirós-Funosas, R.; Prohens, R.; Barbas, R.; El-Faham, A.; Albericio, F. Oxyma: An efficient additive for peptide synthesis to replace the benzotriazole-based HOBt and HOAt with a lower risk of explosion. Chemistry 2009, 15, 9394-9403. [CrossRef]

143. El-Faham, A.; Albericio, F. Peptide coupling reagents, more than a letter soup. Chem. Rev. 2011, 111, 6557-6602. [CrossRef] [PubMed]

144. Chan, W.C.; White, P.D. Fmoc Solid Phase Peptide Synthesis: A Practical Approach; OUP: Oxford, UK, 2000; ISBN 978-0-19-963724-9.

145. Sheppard, R. The Fluorenylmethoxycarbonyl Group in Solid Phase Synthesis. J. Pept. Sci. 2003, 9, 545-552. [CrossRef] [PubMed]

146. Haack, T.; Mutter, M. Serine derived oxazolidines as secondary structure disrupting, solubilizing building blocks in peptide synthesis. Tetrahedron Lett. 1992, 33, 1589-1592. [CrossRef]

147. Sohma, Y.; Sasaki, M.; Hayashi, Y.; Kimura, T.; Kiso, Y. Novel and efficient synthesis of difficult sequence-containing peptides through $\mathrm{O}-\mathrm{N}$ intramolecular acyl migration reaction of $\mathrm{O}$-acyl isopeptides. Chem. Commun. 2004, 124-125. [CrossRef] [PubMed]

148. Carpino, L.A.; Krause, E.; Sferdean, C.D.; Schümann, M.; Fabian, H.; Bienert, M.; Beyermann, M. Synthesis of 'difficult' peptide sequences: Application of a depsipeptide technique to the Jung-Redemann 10- and 26-mers and the amyloid peptide A $\beta(1-42)$. Tetrahedron Lett. 2004, 45, 7519-7523. [CrossRef]

149. Mutter, M.; Chandravarkar, A.; Boyat, C.; Lopez, J.; Santos, S.D.; Mandal, B.; Mimna, R.; Murat, K.; Patiny, L.; Saucède, L.; et al. Switch Peptides In Statu Nascendi: Induction of Conformational Transitions Relevant to Degenerative Diseases. Angew. Chem. Int. Ed. 2004, 43, 4172-4178. [CrossRef]

150. Abedini, A.; Raleigh, D.P. Incorporation of Pseudoproline Derivatives Allows the Facile Synthesis of Human IAPP, a Highly Amyloidogenic and Aggregation-Prone Polypeptide. Org. Lett. 2005, 7, 693-696. [CrossRef]

151. Harris, P.W.R.; Kowalczyk, R.; Hay, D.L.; Brimble, M.A. A Single Pseudoproline and Microwave Solid Phase Peptide Synthesis Facilitates an Efficient Synthesis of Human Amylin 1-37. Int. J. Pept. Res. Ther. 2013, 19, 147-155. [CrossRef]

152. Wöhr, T.; Wahl, F.; Nefzi, A.; Rohwedder, B.; Sato, T.; Sun, X.C.; Mutter, M. Pseudo-prolines as a solubilizing, structure-disrupting protection technique in peptide synthesis. J. Am. Chem. Soc. 1996, 118, 9218-9227. [CrossRef]

153. Tuchscherer, G.; Mutter, M. Peptidomimetics for Bridging Structure and Function: Pseudo-Prolines (YPro) in Peptide Synthesis, Molecular Recognition, and Drug Design. Chimia 2001, 55, 306-313.

154. Skropeta, D.; Jolliffe, K.A.; Turner, P. Pseudoprolines as Removable Turn Inducers: Tools for the Cyclization of Small Peptides. J. Org. Chem. 2004, 69, 8804-8809. [CrossRef] [PubMed]

155. Postma, T.M.; Albericio, F. Cysteine pseudoprolines for thiol protection and peptide macrocyclization enhancement in Fmoc-based solid-phase peptide synthesis. Org. Lett. 2014, 16, 1772-1775. [CrossRef] [PubMed]

156. Sohma, Y.; Yoshiya, T.; Taniguchi, A.; Kimura, T.; Hayashi, Y.; Kiso, Y. Development of O-Acyl Isopeptide Method. Biopolymers 2007, 88, 253-262. [CrossRef] [PubMed]

157. Sohma, Y.; Taniguchi, A.; Skwarczynski, M.; Yoshiya, T.; Fukao, F.; Kimura, T.; Hayashi, Y.; Kiso, Y. 'O-Acyl isopeptide method' for the efficient synthesis of difficult sequence-containing peptides: Use of 'O-acyl isodipeptide unit'. Tetrahedron Lett. 2006, 47, 3013-3017. [CrossRef] 
158. Yoshiya, T.; Taniguchi, A.; Sohma, Y.; Fukao, F.; Nakamura, S.; Abe, N.; Ito, N.; Skwarczynski, M.; Kimura, T.; Hayashi, Y.; et al. 'O-Acyl isopeptide method' for peptide synthesis: Synthesis of forty kinds of 'O-acyl isodipeptide unit' Boc-Ser/Thr(Fmoc-Xaa)OH. Org. Biomol. Chem. 2007, 5, 1720-1730. [CrossRef] [PubMed]

159. Taniguchi, A.; Yoshiya, T.; Abe, N.; Fukao, F.; Sohma, Y.; Kimura, T.; Hayashi, Y.; Kiso, Y. 'O-Acyl isopeptide method' for peptide synthesis: Solvent effects in the synthesis of A $\beta 1-42$ isopeptide using 'O-acyl isodipeptide unit'. J. Pept. Sci. 2007, 13, 868-874. [CrossRef]

160. Yoshiya, T.; Ito, N.; Kimura, T.; Kiso, Y. Isopeptide method: Development of S-acyl isopeptide method for the synthesis of difficult sequence-containing peptides. J. Pept. Sci. 2008, 14, 1203-1208. [CrossRef]

161. Sohma, Y.; Sasaki, M.; Hayashi, Y.; Kimura, T.; Kiso, Y. Design and synthesis of a novel water-soluble A $\beta 42$ isopeptide: An efficient strategy for the preparation of Alzheimer's disease-related peptide, A $\beta 1-42$, via $O-N$ intramolecular acyl migration reaction. Tetrahedron Lett. 2004, 45, 5965-5968. [CrossRef]

162. Yoshiya, T.; Higa, A.; Abe, N.; Fukao, F.; Kuruma, T.; Toda, Y.; Sohma, Y.; Kiso, Y. Click peptide concept: O-acyl isopeptide of islet amyloid polypeptide as a nonaggregative precursor molecule. ChemBioChem 2011, 12, 1216-1222. [CrossRef]

163. Hussein, W.M.; Liu, T.Y.; Toth, I.; Skwarczynski, M. Microwave-assisted synthesis of difficult sequence-containing peptides using the isopeptide method. Org. Biomol. Chem. 2013, 11, 2370-2376. [CrossRef]

164. Wu, F.; Mayer, J.P.; Gelfanov, V.M.; Liu, F.; DiMarchi, R.D. Synthesis of Four-Disulfide Insulin Analogs via Sequential Disulfide Bond Formation. J. Org. Chem. 2017, 82, 3506-3512. [CrossRef] [PubMed]

165. Liu, F.; Luo, E.Y.; Flora, D.B.; Mezo, A.R. A synthetic route to human insulin using isoacyl peptides. Angew. Chem. Int. Ed. 2014, 53, 3983-3987. [CrossRef] [PubMed]

166. Karas, J.A.; Scanlon, D.B.; Forbes, B.E.; Vetter, I.; Lewis, R.J.; Gardiner, J.; Separovic, F.; Wade, J.D.; Hossain, M.A. 2-Nitroveratryl as a photocleavable thiol-protecting group for directed disulfide bond formation in the chemical synthesis of insulin. Chem. Eur. J. 2014, 20, 9549-9552. [CrossRef] [PubMed]

167. Arai, K.; Takei, T.; Shinozaki, R.; Noguchi, M.; Fujisawa, S.; Katayama, H.; Moroder, L.; Ando, S.; Okumura, M.; Inaba, K.; et al. Characterization and optimization of two-chain folding pathways of insulin via native chain assembly. Commun. Chem. 2018, 1, 26-37. [CrossRef]

168. Kanai, S.; Machida, K.; Masuda, R.; Koide, T. Peptide precursors that acquire denatured collagen-hybridizing ability by O-to-N acyl migration at physiological pH. Org. Biomol. Chem. 2020, 18, 2823-2827. [CrossRef] [PubMed]

169. Taniguchi, A.; Sohma, Y.; Hirayama, Y.; Mukai, H.; Kimura, T.; Hayashi, Y.; Matsuzaki, K.; Kiso, Y. “Click Peptide”: pH-Triggered in Situ Production and Aggregation of Monomer Aß1-42. ChemBioChem 2009, 10, 710-715. [CrossRef]

170. Yoshiya, T.; Sohma, Y.; Kimura, T.; Hayashi, Y.; Kiso, Y. 'O-Acyl isopeptide method': Racemization-free segment condensation in solid phase peptide synthesis. Tetrahedron Lett. 2006, 47, 7905-7909. [CrossRef]

171. Coin, I.; Schmieder, P.; Bienert, M.; Beyermann, M. The depsipeptide technique applied to peptide segment condensation: Scope and limitations. J. Pept. Sci. 2008, 14, 299-306. [CrossRef]

172. Yoshiya, T.; Kawashima, H.; Sohma, Y.; Kimura, T.; Kiso, Y. O-Acyl isopeptide method: Efficient synthesis of isopeptide segment and application to racemization-free segment condensation. Org. Biomol. Chem. 2009, 7, 2894-2904. [CrossRef]

173. Lecaillon, J.; Gilles, P.; Subra, G.; Martinez, J.; Amblard, M. Synthesis of cyclic peptides via O-N-acyl migration. Tetrahedron Lett. 2008, 49, 4674-4676. [CrossRef]

174. Yoshiya, T.; Kawashima, H.; Hasegawa, Y.; Okamoto, K.; Kimura, T.; Sohma, Y.; Kiso, Y. Epimerization-free synthesis of cyclic peptide by use of the O-acyl isopeptide method. J. Pept. Sci. 2010, 16, 437-442. [CrossRef] [PubMed]

175. Leach, A. Molecular Modelling: Principles and Applications, 2nd ed.; Prentice Hall, Inc.: Upper Saddle River, NJ, USA, 2001.

176. Beachy, M.D.; Chasman, D.; Murphy, R.B.; Halgren, T.A.; Friesner, R.A. Accurate ab Initio Quantum Chemical Determination of the Relative Energetics of Peptide Conformations and Assessment of Empirical Force Fields. J. Am. Chem. Soc. 1997, 119, 5908-5920. [CrossRef]

177. Sapse, A.M. Molecular Orbital Calculations for Amino Acids and Peptides; Springer Science \& Business Media: Bazylei, Switzerland, 2012.

178. Rossi, M.; Chutia, S.; Scheffler, M.; Blum, V. Validation Challenge of Density-Functional Theory for Peptides-Example of Ac-Phe-Ala5-LysH+. J. Phys. Chem. A 2014, 118, 7349-7359. [CrossRef] [PubMed]

179. Jwad, R.; Weissberger, D.; Hunter, L. Strategies for Fine-Tuning the Conformations of Cyclic Peptides. Chem. Rev. 2020, 120, 9743-9789. [CrossRef] [PubMed]

180. Mata, R.A.; Suhm, M.A. Benchmarking Quantum Chemical Methods: Are We Heading in the Right Direction? Angew. Chem. Int. Ed. 2017, 56, 11011-11018. [CrossRef]

181. Lexa, K.W.; Alser, K.A.; Salisburg, A.M.; Ellens, D.J.; Hernandez, L.; Bono, S.J.; Michael, H.C.; Derby, J.R.; Skiba, J.G.; Feldgus, S.; et al. The search for low energy conformational families of small peptides: Searching for active conformations of small peptides in the absence of a known receptor. Int. J. Quantum Chem. 2007, 107, 3001-3012. [CrossRef]

182. Shields, G.C. Computational approaches for the design of peptides with anti-breast cancer properties. Future Med. Chem. 2009, 1, 201-212. [CrossRef]

183. Berendsen, H.J.; Hayward, S. Collective protein dynamics in relation to function. Curr. Opin. Struct. Biol. 2000, 10, 165-169. [CrossRef] 
184. Zhang, Z.; Shi, Y.; Liu, H. Molecular dynamics simulations of peptides and proteins with amplified collective motions. Biophys. J. 2003, 84, 3583-3593. [CrossRef]

185. Copps, J.; Murphy, R.F.; Lovas, S. Molecular Dynamics Simulations of Peptides. In Peptide-Based Drug Design; Otvos, L., Ed.; Methods In Molecular Biology ${ }^{\mathrm{TM}}$; Humana Press: Totowa, NJ, USA, 2008; Volume 494. [CrossRef]

186. Luzik, D.A.; Rogacheva, O.N.; Izmailov, S.A.; Indeykina, M.I.; Kononikhin, S.; Skrynnikov, R. Molecular Dynamics model of peptide-protein conjugation: Case study of covalent complex between Sos1 peptide and N-terminal SH3 domain from Grb2. Sci. Rep. 2019, 9. [CrossRef]

187. Geng, H.; Chen, F.; Ye, J.; Jiang, F. Applications of Molecular Dynamics Simulation in Structure Prediction of Peptides and Proteins. Comput. Struct. Biotechnol. J. 2019, 17, 1162-1170. [CrossRef] [PubMed]

188. Georgoulia, P.S.; Glykos, N.M. Molecular simulation of peptides coming of age: Accurate prediction of folding, dynamics and structures. Arch. Biochem. Biophys. 2019, 664, 76-88. [CrossRef] [PubMed]

189. Bonomi, M.; Gervasio, F.L.; Tiana, G.; Provasi, D.; Broglia, R.A.; Parrinello, M. Insight into the folding inhibition of the HIV-1 protease by a small peptide. Biophys. J. 2007, 93, 2813-2821. [CrossRef] [PubMed]

190. Fernández-Bachiller, M.I.; Brzozowska, I.; Odolczyk, N.; Zielenkiewicz, U.; Zielenkiewicz, P.; Rademann, J. Mapping ProteinProtein Interactions of the Resistance-Related Bacterial Zeta Toxin-Epsilon Antitoxin Complex $\left(\varepsilon_{2} \zeta_{2}\right)$ with High Affinity Peptide Ligands Using Fluorescence Polarization. Toxins (Basel) 2016, 8, 222. [CrossRef]

191. Kumar, R.; Chaudhary, K.; Sharma, M.; Nagpal, G.; Chauhan, J.S.; Singh, S.; Gautam, A.; Raghava, G.P.S. AHTPDB: A comprehensive platform for analysis and presentation of antihypertensive peptides. Nucleic Acids Res. 2015, 43, D956-D962. [CrossRef]

192. Balatti, G.; Martini, M.F.; Pickholz, M. A Coarse Grain Approach to Study the Antimicrobial Peptides Aurein 1.2 and Maculatin 1.1 interactions with POPG/POPE Lipid Mixtures. J. Mol. Model. 2018, 24, 208-217. [CrossRef]

193. Ulmschneider, J.P.; Ulmschneider, M.B. Cell penetrating peptides, novel vectors for gene therapy. Acc. Chem. Res. 2018, 51, 1106-1116. [CrossRef]

194. Albano, J.M.R. Eneida de Paula and Monica Pickholz (November 5th 2018). In Molecular Dynamics Simulations to Study Drug Delivery Systems, Molecular Dynamics, Alexander Vakhrushev; IntechOpen. Available online: https://www.intechopen.com/ books/molecular-dynamics/molecular-dynamics-simulations-to-study-drug-delivery-systems (accessed on 5 November 2018). [CrossRef]

195. Marrink, S.J.; Risselada, H.J.; Yefimov, S.; Tieleman, D.P.; de Vries, A.H. The MARTINI force field: Coarse grained model for biomolecular simulations. J. Phys. Chem. B 2007, 111, 7812-7824. [CrossRef]

196. Winger, M.; Trzesniak, D.; Baron, R.; van Gunsteren, W.F. On using a too large integration time step in molecular dynamics simulations of coarse-grained molecular models. Phys. Chem. Chem. Phys. 2009, 11, 1934-1941. [CrossRef]

197. Zhao, L.; Cao, Z.; Bian, Y.; Hu, G.; Wang, J.; Zhou, Y. Molecular Dynamics Simulations of Human Antimicrobial Peptide LL-37 in Model POPC and POPG Lipid Bilayers. Int. J. Mol. Sci. 2018, 19, 1186. [CrossRef]

198. Gumbart, J.C.; Ulmschneider, M.B.; Hazel, A.; White, S.H.; Ulmschneider, J.P. Computed Free Energies of Peptide Insertion into Bilayers are Independent of Computational Method. J. Membr. Biol. 2018, 251, 345-356. [CrossRef]

199. Hu, Y.; Ou, S.; Patel, S. Free energetics of arginine permeation into model DMPC lipid bilayers: Coupling of effective counterion concentration and lateral bilayer dimensions. J. Phys. Chem. B 2013, 117, 11641-11653. [CrossRef]

200. Kabelka, I.; Vácha, R. Optimal Hydrophobicity and Reorientation of Amphiphilic Peptides Translocating through Membrane. Biophys. J. 2018, 115, 1045-1054. [CrossRef]

201. Do, P.C.; Lee, E.H.; Le, L. Steered molecular dynamics simulation in rational drug design. Chem. Inf. Model. 2018, 58, 1473-1482. [CrossRef] [PubMed]

202. Cao, Z.; Liu, L.; Hu, G.; Bian, Y.; Li, H.; Wang, J.; Zhou, Y. Interplay of hydrophobic and hydrophilic interactions in sequencedependent cell penetration of spontaneous membrane-translocating peptides revealed by bias-exchange metadynamics simulations. Biochim. Biophys. Acta Biomembr. 2020, 1862, 183402-183414. [CrossRef] [PubMed]

203. Balatti, G.E.; Ambroggio, E.E.; Fidelio, G.D.; Martini, M.F.; Pickholz, M. Differential Interaction of Antimicrobial Peptides with Lipid Structures Studied by Coarse-Grained Molecular Dynamics Simulations. Molecules 2017, 22, 1775-1792. [CrossRef] [PubMed]

204. Balatti, G.E.; Domene, C.; Martini, M.F.; Pickholz, M.J. Differential Stability of Aurein 1.2 Pores in Model Membranes of Two Probiotic Strains. Chem. Inf. Model. 2020, 20. [CrossRef]

205. Traboulsi, H.; Larkin, H.; Bonin, M.-A.; Volkov, L.; Lavoie, C.L.; Marsault, E.R. Macrocyclic cell penetrating peptides: A study of structure-penetration properties. Bioconjug. Chem. 2015, 26, 405-411. [CrossRef] [PubMed]

206. Qian, Z.; Martyna, A.; Hard, R.L.; Wang, J.; Appiah-Kubi, G.; Coss, C.; Phelps, M.A.; Rossman, J.S.; Pei, D. Discovery and mechanism of highly efficient cyclic cell-penetrating peptides. Biochemistry 2016, 55, 2601-2612. [CrossRef]

207. Reissmann, S. Cell penetration: Scope and limitations by the application of cell-penetrating peptides. J. Pept. Sci. 2014, 20, 760-784. [CrossRef]

208. Ali, M.; Amon, M.; Bender, V.; Bolte, A.; Separovic, F.; Benson, H.; Manolios, N. Cyclization enhances function of linear anti-arthritic peptides. Clin. Immunol. 2014, 150, 121-133. [CrossRef] [PubMed]

209. Mandal, D.; Nasrolahi Shirazi, A.; Parang, K. Cell-penetrating homochiral cyclic peptides as nuclear-targeting molecular transporters. Angew. Chem. Int. Ed. 2011, 50, 9633-9637. [CrossRef] 
210. Nasrolahi Shirazi, A.; Salem El-Sayed, N.; Kumar Tiwari, R.; Tavakoli, K.; Parang, K. Cyclic peptide containing hydrophobic and positively charged residues as a drug delivery system for curcumin. Curr. Drug Deliv. 2016, 13, 409-417. [CrossRef] [PubMed]

211. Nasrolahi Shirazi, A.; Tiwari, R.; Chhikara, B.S.; Mandal, D.; Parang, K. Design and biological evaluation of cell-penetrating peptide-doxorubicin conjugates as prodrugs. Mol. Pharm. 2013, 10, 488-499. [CrossRef]

212. Nasrolahi Shirazi, A.; Tiwari, R.K.; Oh, D.; Banerjee, A.; Yadav, A.; Parang, K. Efficient delivery of cell impermeable phosphopeptides by a cyclic peptide amphiphile containing tryptophan and arginine. Mol. Pharm. 2013, 10, 2008-2020. [CrossRef]

213. Nasrolahi Shirazi, A.; Tiwari, R.K.; Oh, D.; Sullivan, B.; McCaffrey, K.; Mandal, D.; Parang, K. Surface decorated gold nanoparticles by linear and cyclic peptides as molecular transporters. Mol. Pharm. 2013, 10, 3137-3151. [CrossRef]

214. El-Sayed, N.; Miyake, T.; Shirazi, A.; Park, S.; Clark, J.; Buchholz, S.; Parang, K.; Tiwari, R. Design, synthesis and evaluation of homochiral peptides containing arginine and histidine as molecular transporters. Molecules 2018, 23, 1590-1605. [CrossRef]

215. Oh, D.; Sun, J.; Nasrolahi Shirazi, A.; LaPlante, K.L.; Rowley, D.C.; Parang, K. Antibacterial activities of amphiphilic cyclic cell-penetrating peptides against multidrug-resistant pathogens. Mol. Pharm. 2014, 11, 3528-3536. [CrossRef]

216. Darwish, S.; Sadeghiani, N.; Fong, S.; Mozaffari, S.; Hamidi, P.; Withana, T.; Yang, S.; Tiwari, R.K.; Parang, K. Synthesis and antiproliferative activities of doxorubicin thiol conjugates and doxorubicin-SS-cyclic peptide. Eur. J. Med. Chem. 2019, 161, 594-606. [CrossRef]

217. Shirazi, A.; Mozaffari, S.; Sherpa, R.; Tiwari, R.; Parang, K. Efficient intracellular delivery of cell-impermeable cargo molecules by peptides containing tryptophan and histidine. Molecules 2018, 23, 1536-1548. [CrossRef]

218. Shirazi, A.N.; El-Sayed, N.S.; Mandal, D.; Tiwari, R.K.; Tavakoli, K.; Etesham, M.; Parang, K. Cysteine and arginine-rich peptides as molecular carriers. Bioorg. Med. Chem. Lett. 2016, 26, 656-661. [CrossRef] [PubMed]

219. Oh, D.; Darwish, S.A.; Shirazi, A.N.; Tiwari, R.K.; Parang, K. Amphiphilic bicyclic peptides as cellular delivery agents. ChemMedChem 2016, 11, 2095. [CrossRef]

220. El-Sayed, N.S.; Shirazi, A.N.; Sajid, M.I.; Park, S.E.; Parang, K.; Tiwari, R.K. Synthesis and antiproliferative activities of conjugates of paclitaxel and camptothecin with a cyclic cell-penetrating peptide. Molecules 2019, 24, 1427. [CrossRef] [PubMed]

221. Kumar, S.; Mandal, D.; El-Mowafi, S.A.; Mozaffari, S.; Tiwari, R.K.; Parang, K. Click-free synthesis of a multivalent tricyclic peptide as a molecular transporter. Pharmaceutics 2020, 12, 842-859. [CrossRef]

222. Vazquez-Lombardi, R.; Phan, T.G.; Zimmermann, C.; Lowe, D.; Jermutus, L.; Christ, D. Challenges and opportunities for non-antibody scaffold drugs. Drug Discov. Today 2015, 20, 1271-1283. [CrossRef]

223. Löfblom, J.; Feldwisch, J.; Tolmachev, V.; Carlsson, J.; Stahl, S.; Frejd, F.Y. Affibody molecules: Engineered proteins for therapeutic, diagnostic and biotechnological applications. FEBS Lett. 2010, 584, 2670-2680. [CrossRef]

224. Parhiz, H.; Khoshnejad, M.; Myerson, J.W.; Hood, E.; Patel, P.N.; Brenner, J.S.; Muzykantov, V.R. Unintended effects of drug carriers: Big issues of small particles. Adv. Drug Deliv. Rev. 2018, 130, 90-112. [CrossRef]

225. Andrieu, J.; Re, F.; Russo, L.; Nicotra, F. Phage-displayed peptides targeting specific tissues and organs. J. Drug Target. 2019, 27, 555-565. [CrossRef]

226. Krumpe, L.R.; Mori, T. Potential of phage-displayed peptide library technology to identify functional targeting peptides. Expert Opin. Drug Discov. 2007, 2, 525. [CrossRef]

227. Hart, S.L.; Harbottle, R.P.; Cooper, R.; Miller, A.; Williamson, R.; Coutelle, C. Gene delivery and expression mediated by an integrin-binding peptide. Gene Ther. 1995, 2, 552-554.

228. Hart, S.L.; Collins, L.; Gustafsson, K.; Fabre, J.W. Integrin-mediated transfection with peptides containing arginine-glycine-aspartic acid domains. Gene Ther. 1997, 4, 1225-1230. [CrossRef] [PubMed]

229. Hart, S.L. Integrin-mediated vectors for gene transfer and therapy. Curr. Opin. Mol. Ther. 1999, 1, 197-203. [PubMed]

230. Avraamides, C.J.; Garmy-Susini, B.; Varner, J.A. Integrins in angiogenesis and lymphangiogenesis. Nat. Rev. Cancer 2008, 8, 604-617. [CrossRef] [PubMed]

231. Brooks, P.C.; Clark, R.A.; Cheresh, D.A. Requirement of vascular integrin alpha beta 3 for angiogenesis. Science 1994, 264, 569-571. [CrossRef] [PubMed]

232. Ng, Q.K.; Sutton, M.K.; Soonsawad, P.; Xing, L.; Cheng, H.; Segura, T. Engineering clustered ligand binding into nonviral vectors: Alphavbeta3 targeting as an example. Mol. Ther. 2009, 17, 828-836. [CrossRef]

233. Ng, Q.K.T.; Su, H.; Armijo, A.L.; Czernin, J.; Radu, C.G.; Segura, T. Clustered Arg-Gly-Asp Peptides Enhances Tumor Targeting of Nonviral Vectors. ChemMedChem 2011, 6, 623-627. [CrossRef]

234. Kang, Z.; Meng, Q.; Liu, K. Peptide-based gene delivery vectors. J. Mater. Chem. B 2019, 7, 1824-1841. [CrossRef] [PubMed]

235. Han, K.; Yang, J.; Chen, S.; Chen, J.X.; Liu, C.W.; Li, C.; Cheng, H.; Zhuo, R.X.; Zhang, X.Z. Novel gene transfer vectors based on artificial recombinant multi-functional oligopeptides. Int. J. Pharm. 2012, 436, 555-563. [CrossRef] [PubMed]

236. Harisa, G.I.; Faris, T.M. Direct Drug Targeting into Intracellular Compartments: Issues, Limitations, and Future Outlook. J. Membr. Biol. 2019, 252, 527-539. [CrossRef] [PubMed]

237. Pan, T.; Song, W.; Gao, H.; Li, T.; Cao, X.; Zhong, S.; Wang, Y. MiR-29b-Loaded Gold Nanoparticles Targeting to the Endoplasmic Reticulum for Synergistic Promotion of Osteogenic Differentiation. ACS Appl. Mater. Interfaces 2016, 8, 19217-19227. [CrossRef]

238. Agemy, L.; Friedmann-Morvinski, D.; Kotamraju, V.K.; Roth, L.; Sugahara, K.N.; Girard, O.M.; Mattrey, R.F.; Verma, I.M.; Ruoslathi, E. Targeted nanoparticle enhanced proapoptotic peptide as potential therapy for glioblastoma. Proc. Natl. Acad. Sci. USA 2011, 108, 17450-17455. [CrossRef] 
239. Donahue, N.D.; Acar, H.; Wilhelm, S. Concepts of nanoparticle cellular uptake, intracellular trafficking, and kinetics in nanomedicine. Adv. Drug Deliv. Rev. 2019, 143, 68-96. [CrossRef]

240. Guidotti, G.; Brambilla, L.; Rossi, D. Cell-Penetrating Peptides: From Basic Research to Clinics. Trends Pharmacol. Sci. 2017, 38, 406-424. [CrossRef]

241. Vivès, E.; Brodin, P.; Lebleu, B. A truncated HIV-1 Tat protein basic domain rapidly translocates through the plasma membrane and accumulates in the cell nucleus. J. Biol. Chem. 1997, 272, 16010-16017. [CrossRef] [PubMed]

242. Martin, M.E.; Rice, K.G. Peptide-guided gene delivery. AAPS J. 2007, 9, E18-E29. [CrossRef] [PubMed]

243. Lehto, T.; Simonson, O.E.; Mager, I.; Ezzat, K.; Sork, H.; Copolovici, D.M.; Viola, J.R.; Zaghloul, E.M.; Lundin, P.; Moreno, P.M.D.; et al. A peptide-based vector for efficient gene transfer in vitro and in vivo. Mol. Ther. J. Am. Soc. Gene Ther. 2011, 19, 1457-1467. Available online: http:/ / www.nature.com/doifinder/10.1038/mt.2011.10 (accessed on 19 August 2011). [CrossRef] [PubMed]

244. Wyman, T.B.; Nicol, F.; Zelphati, O.; Scaria, P.V.; Plank, C.; Szoka, F.C. Design, synthesis, and characterization of a cationic peptide that binds to nucleic acids and permeabilizes bilayers. Biochemistry 1997, 36, 3008-3017. [CrossRef] [PubMed]

245. Bolhassani, A.; Ghasemi, N.; Servis, C.; Taghikhani, M.; Rafati, S. The efficiency of a novel delivery system (PEI600-Tat) in development of potent DNA vaccine using HPV16 E7 as a model antigen. Drug Deliv. 2009, 16, 196-204. [CrossRef]

246. Zhang, H.; Gerson, T.; Varney, M.L.; Singh, R.K.; Vinogradov, S.V. Multifunctional Peptide-PEG Intercalating Conjugates: Programmatic of Gene Delivery to the Blood-Brain Barrier. Pharm. Res. 2010, 27, 2528-2543. [CrossRef]

247. Gonçalves, E.; Kitas, E.; Seelig, J. Binding of Oligoarginine to Membrane Lipids and Heparan Sulfate: Structural and Thermodynamic Characterization of a Cell-Penetrating Peptide. Biochemistry 2005, 44, 2692-2702. [CrossRef]

248. Ziegler, A.; Blatter, X.L.; Seelig, A.; Seelig, J. Protein transduction domains of HIV-1 and SIV TAT interact with charged lipid vesicles. Binding mechanism and thermodynamic analysis. Biochemistry 2003, 42, 9185-9194. [CrossRef]

249. Binder, H.; Lindblom, G. Charge-Dependent Translocation of the Trojan Peptide Penetratin across Lipid Membranes. Biophys. J. 2003, 85, 982-995. [CrossRef]

250. Christiaens, B.; Symoens, S.; Verheyden, S.; Engelborghs, Y.; Joliot, A.; Prochiantz, A.; Vandekerckhove; Rosseneu, M.; Vanloo, B. Tryptophan fluorescence study of the interaction of penetratin peptides with model membranes. Eur. J. Biochem. 2002, 269, 2918-2926. [CrossRef] [PubMed]

251. Dom, G.; Shaw-Jackson, C.; Matis, C.; Bouffioux, O.; Picard, J.J.; Prochiantz, A.; Mingeot-Leclercq, P.; Brasseur, R.; Rezsohazy, R. Cellular uptake of Antennapedia Penetratin peptides is a two-step process in which phase transfer precedes a tryptophandependent translocation. Nucleic Acids Res. 2003, 31, 556-561. [CrossRef] [PubMed]

252. Canine, B.F.; Wang, Y.; Hatefi, A. Evaluation of the effect of vector architecture on DNA condensation and gene transfer efficiency. J. Control. Release 2008, 129, 117-123. [CrossRef]

253. Marshall, N.B.; Oda, S.K.; London, C.A.; Moulton, H.M.; Iversen, P.L.; Kerkvliet, N.I. and Mourich, D.V. Arginine-rich cellpenetrating peptides facilitate delivery of antisense oligomers into murine leukocytes and alter pre-mRNA splicing. J. Immunol. Methods 2007, 325, 114-126. [CrossRef]

254. Rothbard, J.B.; Kreider, E.; VanDeusen, C.L.; Wright, L.; Wylie, B.; Wender, P.A. Arginine-rich molecular transporters for drug delivery: Role of backbone spacing in cellular uptake. J. Med. Chem. 2002, 45, 3612-3618. [CrossRef]

255. Siprashvili, Z.; Scholl, F.A.; Oliver, S.F.; Adams, A.; Contag, C.H.; Wender, P.A.; Khavari, P.A. Gene transfer via reversible plasmid condensation with cysteine-flanked, internally spaced arginine-rich peptides. Hum. Gene Ther. 2004, 14, 1225-1233. [CrossRef]

256. Futaki, S.; Ohashi, W.; Suzuki, T.; Niwa, M.; Tanaka, S.; Ueda, K.; Harashima, H.; Sugiura, Y. Stearylated arginine-rich peptides: A new class of transfection systems. Bioconjug. Chem. 2001, 12, 1005-1011. [CrossRef]

257. Plank, C.; Oberhauser, B.; Mechtler, K.; Koch, C.; Wagner, E. The influence of endosome-disruptive peptides on gene transfer using synthetic virus-like gene transfer systems. J. Biol. Chem. 1994, 269, 12918-12924. [CrossRef]

258. Wagner, E.; Plank, C.; Zatloukal, K.; Cotten, M.; Birnstiel, M.L. Influenza virus hemagglutinin HA-2 N-terminal fusogenic peptides augment gene transfer by transferrin-polylysine-DNA complexes: Toward a synthetic virus-like gene-transfer vehicle. Proc. Natl. Acad. Sci. USA 1992, 89, 7934-7938. [CrossRef] [PubMed]

259. Gupta, B.; Levchenko, T.S.; Torchilin, V.P. Intracellular delivery of large molecules and small particles by cell-penetrating proteins and peptides. Adv. Drug Deliv. Rev. 2005, 57, 637-651. [CrossRef]

260. Chen, C.P.; Kim, J.S.; Steenblock, E.; Liu, D.; Rice, K.G. Gene Transfer with Poly-Melittin Peptides. Bioconjug. Chem. 2006, 17, 1057-1062. [CrossRef] [PubMed]

261. Ogris, M.; Carlisle, R.C.; Bettinger, T.; Seymour, L.W. Melittin Enables Efficient Vesicular Escape and Enhanced Nuclear Access of Nonviral Gene Delivery Vectors. J. Biol. Chem. 2001, 276, 47550-47555. [CrossRef] [PubMed]

262. Tan, Y.X.; Chen, C.; Wang, Y.L.; Lin, S.; Wang, Y.; Li, S.B.; Jin, X.P.; Gao, H.W.; Du, F.S.; Gong, F.; et al. Truncated peptides from melittin and its analog with high lytic activity at endosomal $\mathrm{pH}$ enhance branched polyethylenimine-mediated gene transfection. J. Gene Med. 2012, 14, 241-250. [CrossRef] [PubMed]

263. Abe, $\mathrm{H}$. Role of histidine-related compounds as intracellular proton buffering constituents in vertebrate muscle. Biochemistry 2000, 65, 757-765.

264. Abe, H.; Dobson, G.P.; Hoeger, U.; Parkhouse, W.S. Role of histidine-related compounds to intracellular buffering in fish skeletal muscle. Am. J. Physiol. 1985, 249, R449-R454. [CrossRef] 
265. Parhiz, H.; Hashemi, M.; Hatefi, A.; Shier, W.T.; Farzad, S.A.; Ramezani, M. Arginine-rich hydrophobic polyethylenimine: Potent agent with simple components for nucleic acid delivery. Int. J. Biol. Macromol. 2013, 60, 18-27. [CrossRef]

266. Mével, M.; Neveu, C.; Goncalves, C.; Yaounanc, J.J.; Pichon, C.; Jaffre, P.A.; Midoux, P. Novel neutral imidazolelipophosphoramides for transfection assays. Chem. Commun. 2008, 3124-3126. [CrossRef]

267. Midoux, P.; Kichler, A.; Boutin, V.; Maurizot, J.C.; Monsigny, M. Membrane permeabilization and efficient gene transfer by a peptide containing several histidines. Bioconjug. Chem. 1998, 9, 260-267. [CrossRef]

268. Wang, X.L.; Nguyen, T.; Gillespie, D.; Jensen, R.; Lu, Z.R. A multifunctional and reversibly polymerizable carrier for efficient siRNA delivery. Biomaterials 2008, 29, 15-22. [CrossRef] [PubMed]

269. Chen, Q.R.; Zhang, L.; Luther, P.W.; Mixson, A.J. Optimal transfection with the HK polymer depends on its degree of branching and the $\mathrm{pH}$ of endocytic vesicles. Nucleic Acids Res. 2002, 30, 1338-1345. [CrossRef] [PubMed]

270. Leng, Q.; Scaria, P.; Zhu, J.; Ambulos, N.; Campbella, P.; Mixson, J. Highly branched HK peptides are effective carriers of siRNA. J. Gene Med. 2005, 7, 977-986. [CrossRef] [PubMed]

271. Dey, D.; Inayathullah, M.; :Lee, A.S.; Limiuex, M.; Zhang, X.; Wu, Y.; Nag, D.; De Almeida, P.E.; Han, L.; Rajadas, J.; et al. Efficient gene delivery of primary human cells using peptide linked polyethylenimine polymer hybrid. Biomaterials 2011, 32, 4647-4658. [CrossRef]

272. Kim, T.H.; Ihm, J.E.; Choi, Y.J.; Nah, J.W.; Cho, C.S. Efficient gene delivery by urocanic acid-modified chitosan. J. Control. Release 2003, 93, 389-402. [CrossRef]

273. Swami, A.; Aggarwal, A.; Pathak, A.; Patnaik, S.; Kumar, P.; Singh, Y.; Gupta, K.C. Imidazolyl-PEI modified nanoparticles for enhanced gene delivery. Int. J. Pharm. 2007, 335, 180-192. [CrossRef]

274. Hébert, E. Improvement of exogenous DNA nuclear importation by nuclear localization signal-bearing vectors: A promising way for non-viral gene therapy? Biol. Cell. 2003, 95, 59-68. [CrossRef]

275. Khalil, I.A.; Hayashi, Y.; Mizuno, R.; Harashima, H. Octaarginine- and pH sensitive fusogenic peptide-modified nanoparticles for liver gene delivery. J. Control Release 2011, 156, 374-380. [CrossRef]

276. Robbins, J.; Dilworth, S.M.; Laskey, R.A.; Dingwall, C. Two interdependent basic domains in nucleoplasmin nuclear targeting sequence: Identification of a class of bipartite nuclear targeting sequence. Cell 1991, 64, 615-623. [CrossRef]

277. Duvshani-Eshet, M.; Oz, H.K.S.; Radzishevsky, I.S.; Mor, A.; Machluf, M. Effect of peptides bearing nuclear localization signals on therapeutic ultrasound mediated gene delivery. J. Gene Med. 2008, 10, 1150-1159. [CrossRef]

278. Ni, Y.H.; Hsu, H.Y.; Chen, P.J.; Chang, M.H. Protamine enhances the efficiency of liposome-mediated gene transfer in a cultured human hepatoma cell line. J. Formos. Med. Assoc. 1999, 98, 562-566.

279. Vázquez, E.; Ferrer-Miralles, N.; Villaverde, A. Peptide-assisted traffic engineering for nonviral gene therapy. Drug Discov. Today 2008, 13, 1067-1074. [CrossRef] [PubMed]

280. Parhiz, H.; Hashemi, M.; Hatefi, A.; Shier, W.T.; Farzad, S.A.; Ramezani, M. Molecular weight-dependent genetic information transfer with disulfide-linked polyethylenimine-based nonviral vectors. J. Biomater. Appl. 2013, 28, 112-124. [CrossRef] [PubMed]

281. Parker, A.L.; Collins, L.; Zhang, X.; Fabre, J.W. Exploration of peptide motifs for potent non-viral gene delivery highly selective for dividing cells. J. Gene Med. 2005, 7, 1545-1554. [CrossRef] [PubMed]

282. Parelkar, S.S.; Chan-Seng, D.; Emrick, T. Reconfiguring polylysine architectures for controlling polyplex binding and non-viral transfection. Biomaterials 2011, 32, 2432-2444. [CrossRef] [PubMed]

283. Smith, G.P.; Petrenko, V.A. Phage Display. Chem. Rev. 1997, 97, 391-410. [CrossRef]

284. Lofblom, J. Bacterial display in combinatorial protein engineering. Biotechnol. J. 2011, 6, 1115-1129. [CrossRef]

285. Hanes, J.; Plückthun, A. In vitro selection and evolution of functional proteins using ribosome display. Proc. Natl. Acad. Sci. USA 1997, 94, 4937-4942. [CrossRef]

286. Roberts, R.W.; Szostak, J.W. RNA-peptide fusions for the in vitro selection of peptides and proteins. Proc. Natl. Acad. Sci. USA 1997, 414, 12297-12302. [CrossRef]

287. Colas, P.; Cohen, B.; Jessen, T.; Grishina, I.; McCoy, J.; Brent, R. Genetic selection of peptide aptamers that recognize and inhibit cyclin-dependent kinase 2. Nature 1996, 380, 548-550. [CrossRef]

288. Kolmar, H. Biological diversity and therapeutic potential of natural and engineered cystine knot miniproteins. Curr. Opin. Pharm. 2009, 9, 608-614. [CrossRef] [PubMed]

289. Byla, P.; Andersen, M.H.; Holtet, T.L.; Jacobsen, H.; Munch, M.; Gad, H.H.; Thogersen, H.C.; Hartman, R. Selection of a novel and highly specific tumor necrosis factor alpha (TNFalpha) antagonist: Insight from the crystal structure of the antagonist-TNF alpha complex. J. Biol. Chem. 2010, 285, 12096-12100. [CrossRef] [PubMed]

290. Heinis, C.; Rutherford, T.; Freund, S.; Winter, G. Phage encoded combinatorial chemical libraries based on bicyclic peptides. Nat. Chem. Biol. 2009, 5, 502-507. [CrossRef] [PubMed]

291. Reverdatto, S.; Burz, D.S.; Shekhtman, A. Peptide aptamers: Development and applications. Curr. Top. Med. Chem. 2015, 15, 1082-1101. [CrossRef] [PubMed]

292. Gronwall, C.; Stahl, S. Engineered affinity proteins-generation and applications. J. Biotechnol. 2009, 140, 254-269. [CrossRef]

293. New, R.; Bansal, G.; Bogus, M.; Zajkowska, K.; Rickelt, S.; Toth, I. Use of Mixed Micelles for Presentation of Building Blocks in a New Combinatorial Discovery Methodology: Proof-of-Concept Studies. Molecules 2013, 18, 3427-3441. [CrossRef]

294. New, R.; Bansal, G.S.; Dryjska, M.; Bogus, M.; Green, P.; Feldmann, M.; Brennan, F. esign and Optimisation of Bioactive Cyclic Peptides: Generation of a Down-Regulator of TNF Secretion. Molecules 2014, 19, 21529-21540. [CrossRef] 
295. Neefjes, J.; Ovaa, H. A peptide's perspective on antigen presentation to the immune system. Nat. Chem. Biol. 2013, 9, 769-775. [CrossRef]

296. Skwarczynski, M.; Toth, I. Peptide-based synthetic vaccines. Chem. Sci. 2016, 7, 842-854. [CrossRef]

297. Malonis, R.J.; Lai, J.R.; Vergnolle, O. Peptide-Based Vaccines: Current Progress and Future Challenges. Chem. Rev. 2020, 120, 3210-3229. [CrossRef]

298. Shi, S.; Zhu, H.; Xia, X.; Liang, Z.; Ma, X.; Sun, B. Vaccine adjuvants: Understanding the structure and mechanism of adjuvanticity. Vaccine 2019, 37, 3167-3178. [CrossRef] [PubMed]

299. Azmi, F.; Ahmad Fuaad, A.A.; Skwarczynski, M.; Toth, I. Recent progress in adjuvant discovery for peptide-based subunit vaccines. Hum. Vaccin. Immunother. 2014, 10, 778-796. [CrossRef] [PubMed]

300. Shi, S.; Liang, Z.; Sun, B. Response to comment on: Vaccine adjuvants: Understanding the structure and mechanism of adjuvanticity. Vaccine 2020, 38, 2759. [CrossRef] [PubMed]

301. Nevagi, R.J.; Skwarczynski, M.; Toth, I. Polymers for subunit vaccine delivery. Eur. Polym. J. 2019, 114, 397-410. [CrossRef]

302. Marasini, N.; Ghaffar, K.A.; Skwarczynski, M.; Toth, I. Liposomes as a Vaccine Delivery System. In Micro- and Nanotechnology in Vaccine Development; Skwarczynski, M., Toth, I., Eds.; William Andrew Inc.: Norwich, UK, 2017; pp. $221-239$.

303. Rudra, J.S.; Mishra, S.; Chong, A.S.; Mitchell, R.A.; Nardin, E.H.; Nussenzweig, V.; Collier, J.H. Self-assembled peptide nanofibers raising durable antibody responses against a malaria epitope. Biomaterials 2012, 33, 6476-6484. [CrossRef] [PubMed]

304. Sun, T.; Han, H.F.; Hudalla, G.A.; Wen, Y.; Pompano, R.R.; Collier, J.H. Thermal stability of self-assembled peptide vaccine materials. Acta Biomater. 2016, 30, 62-71. [CrossRef] [PubMed]

305. Azmi, F.; Ahmad Fuaad, A.A.; Giddam, A.K.; Batzloff, M.R.; Good, M.F.; Skwarczynski, M.; Toth, I. Self-adjuvanting vaccine against group A streptococcus: Application of fibrillized peptide and immunostimulatory lipid as adjuvant. Bioorg. Med. Chem. 2014, 22, 6401-6408. [CrossRef]

306. Skwarczynski, M.; Zhao, G.; Boer, J.C.; Ozberk, V.; Azuar, A.; Cruz, J.G.; Giddam, A.K.; Khalil, Z.G.; Pandey, M.; Shibu, M.A.; et al. Poly(amino acids) as a potent self-adjuvanting delivery system for peptide-based nanovaccines. Sci. Adv. 2020, 6, 2285-2296. [CrossRef]

307. Bartlett, S.; Skwarczynski, M.; Xie, X.; Toth, I.; Loukas, A.; Eichenberger, R.M. Development of natural and unnatural amino acid delivery systems against hookworm infection. Prec. Nanomed. 2020, 3, 471-482. [CrossRef]

308. Nevagi, R.J.; Khalil, Z.G.; Hussein, W.M.; Powell, J.; Batzloff, M.R.; Capon, R.J.; Good, M.F.; Skwarczynski, M.; Toth, I. Polyglutamic acid-trimethyl chitosan-based intranasal peptide nano-vaccine induces potent immune responses against group A streptococcus. Acta Biomater. 2018, 80, 278-287. [CrossRef]

309. Nevagi, R.J.; Dai, W.; Khalil, Z.G.; Hussein, W.M.; Capon, R.J.; Skwarczynski, M.; Toth, I. Self-assembly of trimethyl chitosan and poly(anionic amino acid)-peptide antigen conjugate to produce a potent self-adjuvanting nanovaccine delivery system. Bioorg. Med. Chem. 2019, 27, 3082-3088. [CrossRef] [PubMed]

310. Nevagi, R.J.; Dai, W.; Khalil, Z.G.; Hussein, W.M.; Capon, R.J.; Skwarczynski, M.; Toth, I. Structure-activity relationship of group A streptococcus lipopeptide vaccine candidates in trimethyl chitosan-based self-adjuvanting delivery system. Eur. J. Med. Chem. 2019, 179, 100-108. [CrossRef] [PubMed]

311. Yang, J.R.; Luo, Y.C.; Shibu, M.A.; Toth, I.; Skwarczynski, M. Cell-Penetrating Peptides: Efficient Vectors for Vaccine Delivery. Curr. Drug Deliv. 2019, 16, 430-443. [CrossRef]

312. Calzetta, L.; Pistocchini, E.; Ritondo, B.L.; Roncada, P.; Palma, E.; di Cave, D.; Mattei, M.; Britti, D. Immunoprophylaxis pharmacotherapy against canine leishmaniosis: A systematic review and meta-analysis on the efficacy of vaccines approved in European Union. Vaccine 2020, 38, 6695-6703. [CrossRef]

313. COVAXX. Coronavirus Company News Summary-Pfizer/BioNTech Publishes Pre-Clinical Data for its Lead Candidate-Dasa and COVAXX Partner on Vaccine Clinical Trial in Brazil. Available online: https://www.pharmaceutical-technology.com/ uncategorised/coronavirus-company-news-summary-pfizer-biontech-publishes-pre-clinical-data-for-its-lead-candidatedasa-and-covaxx-partner-on-vaccine-clinical-trial-in-brazil/ (accessed on 11 September 2020).

314. Obara, W.; Kanehira, M.; Katagiri, T.; Kato, R.; Kato, Y.; Takata, R. Present status and future perspective of peptide-based vaccine therapy for urological cancer. Cancer Sci. 2018, 109, 550-559. [CrossRef] [PubMed]

315. Li, W.; Joshi, M.D.; Singhania, S.; Ramsey, K.H.; Murthy, A.K. Peptide vaccine: Progress and challenges. Vaccines (Basel, Switz.) 2014, 2, 515-536. [CrossRef]

316. Magzoub, M. Combating proteins with proteins: Engineering cell-penetrating peptide antagonists of amyloid-beta aggtregation and associated neurotoxicity. DNA Cell Biol. 2020, 39, 920-925. [CrossRef]

317. Caputi, S.; Trubiani, O.; Sinjari, B.; Trofimova, S.; Diomede, F.; Linkova, N.; Diatlova, A.; Khavinson, V. Effect of short peptides on neuronal differentiation of stem cells. Intern. J. Immunopathol. Pharmacol. 2019, 33, 1-12. [CrossRef]

318. Russo, A.F. Overview of neuropeptides: Awakening the senses? J. Head Face Pain 2017, 57, 37-46. [CrossRef]

319. Katsara, M.; Minigo, G.; Plebanski, M.; Apostolopoulos, V. The good, the bad and the ugly: How altered peptide ligands modulate immunity. Expert Opin. Biol. Ther. 2008, 8, 1873-1884. [CrossRef]

320. Kita, H.; Matsumura, S.; He, X.S.; Ansari, A.A.; Lian, Z.X.; Van de Water, J.; Coppel, R.L.; Kaplan, M.M.; Gershwin, M.E. Analysis of TCR antagonism and molecular mimicry of an HLA-A0201-restricted CTL epitope in primary biliary cirrhosis. Hepatology 2002, 36, 918-926. [CrossRef] [PubMed] 
321. Paas-Rozner, M.; Sela, M.; Mozes, E. A dual altered peptide ligand down-regulates myasthenogenic T cell responses by upregulating CD25- and CTLA-4-expressing CD4+ T cells. Proc. Natl. Acad. Sci. USA 2003, 100, 6676-6681. [CrossRef] [PubMed]

322. Han, S.; Donelan, W.; Wang, H.; Reeves, W.; Yang, L.J. Novel autoantigens in type 1 diabetes. Am. J. Transl. Res. 2013, 5, 379-392.

323. Alleva, D.G.; Maki, R.A.; Putnam, A.L.; Robinson, J.M.; Kipnes, M.S.; Dandona, P.; Marks, J.B.; Simmons, D.L.; Greenbaum, C.J.; Jimenez, R.G.; et al. Immunomodulation in type 1 diabetes by NBI-6024, an altered peptide ligand of the insulin B epitope. Scand J. Immunol. 2006, 63, 59-69. [CrossRef] [PubMed]

324. Walter, M.; Philotheou, A.; Bonnici, F.; Ziegler, A.G.; Jimenez, R.; Group, N.B.I.S. No effect of the altered peptide ligand NBI-6024 on beta-cell residual function and insulin needs in new-onset type 1 diabetes. Diabetes Care 2009, 32, 2036-2040. [CrossRef]

325. Agnes, M.C.; Tan, A.; Jordens, R.; Geluk, A.; Roep, B.O.; Ottenhoff, T.; Drijfhout, J.W.; Koning, F. Strongly increased efficiency of altered peptide ligands by mannosylation. Int. Immunol. 1998, 10, 1299-1304. [CrossRef]

326. Dargahi, N.; Katsara, M.; Tselios, T.; Androutsou, M.E.; de Courten, M.; Matsoukas, J.; Apostolopoulos, V. Multiple Sclerosis: Immunopathology and Treatment Update. Brain. Sci. 2017, 7, 78-105. [CrossRef]

327. Katsara, M.; Apostolopoulos, V. Editorial: Multiple Sclerosis: Pathogenesis and Therapeutics. Med. Chem. 2018, 14, 104-105. [CrossRef]

328. Katsara, M.; Matsoukas, J.; Deraos, G.; Apostolopoulos, V. Towards immunotherapeutic drugs and vaccines against multiple sclerosis. Acta Biochim. Biophys. Sin (Shanghai) 2008, 40, 636-642. [CrossRef]

329. Katsara, M.; Deraos, G.; Tselios, T.; Matsoukas, J.; Apostolopoulos, V. Design of novel cyclic altered peptide ligands of myelin basic protein MBP83-99 that modulate immune responses in SJL/J mice. J. Med. Chem. 2008, 51, 3971-3978. [CrossRef]

330. Katsara, M.; Deraos, S.; Tselios, T.V.; Pietersz, G.; Matsoukas, J.; Apostolopoulos, V. Immune responses of linear and cyclic PLP139151 mutant peptides in SJL/J mice: Peptides in their free state versus mannan conjugation. Immunotherapy 2014, 6, 709-724. [CrossRef] [PubMed]

331. Katsara, M.; Yuriev, E.; Ramsland, P.A.; Deraos, G.; Tselios, T.; Matsoukas, J.; Apostolopoulos, V. A double mutation of MBP(83-99) peptide induces IL-4 responses and antagonizes IFN-gamma responses. J. Neuroimmunol. 2008, 200, 77-89. [CrossRef] [PubMed]

332. Katsara, M.; Yuriev, E.; Ramsland, P.A.; Deraos, G.; Tselios, T.; Matsoukas, J.; Apostolopoulos, V. Mannosylation of mutated MBP83-99 peptides diverts immune responses from Th1 to Th2. Mol. Immunol. 2008, 45, 3661-3670. [CrossRef]

333. Katsara, M.; Yuriev, E.; Ramsland, P.A.; Tselios, T.; Deraos, G.; Lourbopoulos, A.; Grigoriadis, N.; Matsoukas, J.; Apostolopoulos, V. Altered peptide ligands of myelin basic protein (MBP87-99) conjugated to reduced mannan modulate immune responses in mice. Immunology 2009, 128, 521-533. [CrossRef] [PubMed]

334. Candia, M.; Kratzer, B.; Pickl, W.F. On Peptides and Altered Peptide Ligands: From Origin, Mode of Action and Design to Clinical Application (Immunotherapy). Int. Arch. Allergy Immunol. 2016, 170, 211-233. [CrossRef] [PubMed]

335. Ruiz, P.J.; Garren, H.; Hirschberg, D.L.; Langer-Gould, A.M.; Levite, M.; Karpuj, M.V.; Southwood, S.; Sette, A.; Conlon, P.; Steinman, L. Microbial epitopes act as altered peptide ligands to prevent experimental autoimmune encephalomyelitis. J. Exp. Med. 1999, 189, 1275-1284. [CrossRef]

336. Reynolds, N.P. Amyloid-like peptide nanofibils as scaffolds for tissue engineering: Progress and challenges. Biointerphases 2019, 14, 40801-40809. [CrossRef]

337. Hellmund, K.S.; Koksch, B. Self-assembling peptides as extracellular matrix mimics to influence stem cell's fate. Front. Chem. 2019, 7. [CrossRef]

338. Sinjari, B.; Diomede, F.; Khavinson, V.; Mironova, E.; Linkova, N.; Trofimova, S.; Trubiani, O.; Caputi, S. Short peptides protect oral stem cells from ageing. Stem Cell Rev. Rep. 2020, 16, 159-166. [CrossRef]

339. Tatman, P.D.; Muhonen, E.G.; Wickers, S.T.; Gee, A.O.; Kim, E.S.; Kim, D.H. Self-assembling peptides for stem cell and tissue engineering. Biomater. Sci. 2016, 4, 543-544. [CrossRef]

340. Khavinson, V.; Diomede, F.; Mironova, E.; Linkova, N.; Trofimova, S.; Trubiani, O.; Caputi, S.; Sinjari, B. AEDG peptide (epitalon) stimulates gene expression and protein synthesis during neurogenesis: Possible epigenetic mechanism. Molecules 2020, 25, 609-626. [CrossRef] [PubMed]

341. Sharma, S.; Kulkarni, C.; Kulkarni, M.M.; Ali, R.; Porwal, K.; Chattopadhyay, N. Tripeptide-induced modulation of mesenchymal stem cell biomechanics stimulates proliferation and wound healing. Chem. Commun. 2020, 56, 3043-3046. [CrossRef] [PubMed]

342. Ghosh, A.K.; Brindisi, M.; Shahabi, D.; Chapman, M.E.; Mesecar, A.D. Drug development and medicinal chemistry efforts toward SARS-coronavirus and covid-19 therapeutics. ChemMedChem 2020, 15, 907-932. [CrossRef] [PubMed]

343. Dömling, A.; Gao, L. Chemistry and Biology of SARS-CoV-2. Chem 2020, 6, 1283-1295. [CrossRef] [PubMed]

344. Cao, B.; Wang, Y.; Wen, D.; Liu, W.; Wang, J.; Fan, G.; Ruan, L.; Song, B.; Cai, Y.; Wei, M.; et al. A trial of lopinavir-ritonavir in adults hospitalized with severe Covid-19. N. Engl. J. Med. 2002, 382, 1787-1799. [CrossRef]

345. Zhang, L.; Lin, D.; Sun, X.; Curth, U.; Drosten, C.; Sauerhering, L.; Becker, S.; Rox, K.; Hilgenfeld, R. Crystal structure of SARS-CoV-2 main protease provides a basis for design of improved alpha-ketoamide inhibitors. Science 2020, 368, 409-412. [CrossRef]

346. Dai, W.H.; Zhang, B.; Jiang, X.M.; Su, X.H.; Li, L.; Zhao, Y.; Xie, X.; Jin, Z.M.; Peng, J.J.; Liu, F.J.; et al. Structure-based design of antiviral drug candidates targeting the SARS-CoV-2 main protease. Science 2020, 368, 1331-1335. [CrossRef]

347. Jin, Z.M.; Du, X.Y.; Xu, Y.C.; Deng, Y.Q.; Liu, M.Q.; Zhao, Y.; Zhang, B.; Li, X.F.; Zhang, L.K.; Peng, C.; et al. Structure of Mpro from SARS-CoV-2 and discovery of its inhibitors. Nature 2020, 582, 289-293. [CrossRef] 
348. Liu, X.; Wang, X.J. Potential inhibitors against 2019-nCoV coronavirus M protease from clinically approved medicines. J. Genet. Genom. 2020, 47, 119-121. [CrossRef]

349. Wrapp, D.; Wang, N.; Corbett, K.S.; Goldsmith, J.A.; Hsieh, C.L.; Abiona, O.; Graham, B.S.; McLellan, J.S. Cryo-EM structure of the 2019-nCoV spike in the prefusion conformation. Science 2020, 367, 1260-1263. [CrossRef]

350. Yan, R.; Zhang, Y.; Li, Y.; Xia, L.; Guo, Y.; Zhou, Q. Structural basis for the recognition of the SARS-CoV-2 by full-length human ACE2. Science 2020, 367, 1444-1448. [CrossRef] [PubMed]

351. Zhang, G.; Pomplun, S.; Loftis1, A.R.; Loas, A.; Pentelute, B.L. The first-in-class peptide binder to the SARS-CoV-2 spike protein. bioRxiv 2020. [CrossRef]

352. Han, Y.X.; Král, P. Computational design of ACE2-based peptide inhibitors of SARS-CoV-2. ACS Nano 2020, 14, 5143-5147. [CrossRef] [PubMed]

353. Baig, M.S.; Alagumuthu, M.; Rajpoot, S.; Saqib, U. Identification of a potential peptide inhibitor of SARS-CoV-2 targeting its entry into the host cells. Drugs RED 2020, 20, 161-169. [CrossRef]

354. Wu, Z.; McGoogan, J.M. Characteristics of and important lessons from the Coronavirus disease 2019 (COVID-19) outbreak in China: Summary of a report of 72314 cases from the Chinese Center for Disease Control and Prevention. JAMA 2020. [CrossRef]

355. Zhang, J.; Zeng, H.; Gu, J.; Li, H.; Zheng, L.; Zou, Q. Progress and Prospects on Vaccine Development against SARS-CoV-2. Vaccines 2020, 8, 153-165. [CrossRef]

356. Mak, T.M.; Saunders, M.E. Vaccines and Clinical Immunization. In The Immune Response; Mak, T.M., Saunders, M.E., Eds.; Elsevier: Amsterdam, The Netherlands, 2006; pp. 695-749.

357. AlKhazindar, M.; Elnagdy, S.M. Can Lactoferrin Boost Human Immunity Against COVID-19? Pathog. Glob. Health 2020. [CrossRef]

358. Sherman, M.P.; Pritzl, C.J.; Xia, C.; Miller, M.M.; Zaghouani, H.; Hahm, B. Lactoferrin Acts as an Adjuvant During Influenza Vaccination of Neonatal Mice. Biochem. Biophys. Res. Commun. 2015, 467, 766-770. [CrossRef]

359. Hossain, A.K.M.M. The Effect of Model Foods Rich in Bioactive Compounds on Brain-Gut Regulation and Neurodegeneration. Ph.D. Thesis, Lincoln University, Lincoln, New Zealand, 2018.

360. Mada, S.B.; Ugwu, C.P.; Abarshi, M.A. Health Promoting Effects of Food-Derived Bioactive Peptides: A Review. Int. J. Pept. Res. Ther. 2020, 26, 831-848. [CrossRef]

361. Jayaprakash, R.; Perera, C.O. Partial purification and characterization of bioactive peptides from cooked New Zealand greenlipped mussel (Perna canaliculus) protein hydrolyzates. Foods 2020, 9, 1-19. [CrossRef]

362. Faridy, J.C.M.; Paredes-López, O. Plant Foods Hum. Nutr; Springer: Berlin, Germany, 2020; Volume 75, pp. 1573-9104.

363. Minkiewicz, P.; Iwaniak, A.; Darewicz, M. BIPEP-UWM Database of bioactive peptides: Current opportunities. Int. J. Mol. Sci. 2015, 16, 20748-20773. [CrossRef] [PubMed]

364. Wang, A.; Wang, Q.; Qian, J.; Liang, Q.; Wang, Z.; Xu, J.; He, S.; Ma, H. Bioavailability and bioavailable forms of collagen after oral administration to rats. J. Agric. Food Chem. 2015, 63, 3752-3756. [CrossRef] [PubMed]

365. Cicero, A.F.; Fogacci, F.; Coletti, A. Potential role of bioactive peptides in prevention and treatment of chronic diseases: A narrative review. Brit. J. Pharm. 2017, 174, 1378-1394. [CrossRef] [PubMed]

366. Cicero, A.F.; Colletti, A. Nutraceuticals and blood pressure control: Results from clinical trials and meta-analyses. High Blood Press. Cardiovasc. Prev. 2015, 22, 203-213. [CrossRef] [PubMed]

367. Maestri, E.; Marmiroli, M.; Marmiroli, N. Bioactive peptides in plant-derived foodstuffs. J. Proteom. 2016, 147, 140-155. [CrossRef]

368. Bouglé, D.; Bouhallab, S. Dietary bioactive peptides: Human studies. Crit. Rev. Food. Sci. Nutr. 2017, 57, 335-343. [CrossRef]

369. Panchaud, A.M.; Affolter, M.; Kussmann, M. Mass spectrometry for nutritional peptidomics: How to analyse food bioactives and their health effects. J. Proteom. 2012, 75, 3546-3559. [CrossRef]

370. Harnedy, P.A.; FitzGerald, R.J. Bioactive peptides from marine processing waste and shellfish: A review. J. Funct. Foods 2012, 4, 6-24. [CrossRef]

371. Zheng, Z.; Jiang, H.; Huang, Y.; Wang, J.; Qiu, L.; Hu, Z.; Ma, X.; Lu, Y. Screening of an anti-inflammatory peptide from Hydrophis cyanocinctus and analysis of its activities and mechanism in DSS-induced acute colitis. Sci. Rep. 2016, 6, 25672-25683. [CrossRef]

372. Wu, G.; Wang, J.; Luo, P.; Li, A.; Tian, S.; Jiang, H.; Xia, Z. Hydrostatin-SN1, a sea snake-derived bioactive peptide, reduces inflammation in a mouse model of acute lung injury. Front. Pharmacol. 2017, 8, 246-255. [CrossRef]

373. Quah, Y.; Mohd Ismail, N.I.; Ooi, J.L.S.; Affendi, Y.A.; Abd Manan, F.; Teh, L.K.; Wong, F.C.; Chai, T.T. Purification and identification of novel cytotoxic oligopeptides from soft coral Sarcophyton glaucum. J. Zhejiang Univ. Sci. B 2019, 20, 59-70. [CrossRef] [PubMed]

374. Quah, Y.; Mohd Ismail, N.I.; Ooi, J.L.S.; Affendi, Y.A.; Abd Manan, F.; Wong, F.-C.; Chai, T.-T. Identification of novel cytotoxic peptide KENPVLSLVNGMF from marine sponge Xestospongia testudinaria, with characterization of stability in human serum. Int. J. Pept. Res. Ther. 2018, 24, 189-199. [CrossRef]

375. Nikoo, M.; Xu, X.; Ahmadi Gavlighi, H. Chapter 17-Seafood waste-derived peptides: Their antioxidant activity and potential as alternative preservatives in fish products. In Protein Byproducts; Dhillon, G.S., Ed.; Academic Press: New York, NY, USA, 2016; pp. 315-332.

376. Chai, T.T.; Law, Y.C.; Wong, F.C.; Kim, S.K. Enzyme-assisted discovery of antioxidant peptides from edible marine invertebrates: A review. Mar. Drugs 2017, 15, 42-68. [CrossRef]

377. Zhang, L.; Falla, T.J. Cosmeceuticals and peptides. Clin. Dermatol. 2009, 27, 485-494. [CrossRef] 
378. Lima, T.N.; Pedriali Moraes, C.A. Bioactive peptides: Applications and relevance. Cosmetics 2018, 5, 21. [CrossRef]

379. Pandey, A.; Jatana, G.K.; Sonthalia, S. “Cosmeceuticals.” StatPearls. Available online: https://www.ncbi.nlm.nih.gov/pubmed/ 31334943 (accessed on 10 February 2020).

380. Bojarska, J. Amino Acids and Short Peptides as Anti-Aging "Superfood". Int. J. Nutr. Sci. 2020, 5, 1039-1044.

381. Negahdaripour, M.; Owji, H.; Eslami, M.; Zamani, M.; Vakili, B.; Sabetian, S. Selected application of peptide molecules as pharmaceutical agents and in cosmeceuticals. Expert Opin. Biol. Ther. 2019, 19, 1275-1287. [CrossRef]

382. Errante, F.; Ledwoń, P.; Latajka, R.; Rovero, P.; Papini, A.M. Cosmeceutical peptides in the framework of sustainable wellness economy. Front. Chem. 2020, 8. [CrossRef]

383. Schagen, S.K. Topical peptide treatments with effective anti-aging results. Cosmetics 2017, 4, 16-30. [CrossRef]

384. Global Wellness Institute. Global Wellness Economy; Monitor: Miami, FL, USA, 2018; Available online: https:/ /globalwellnessinstitute. org/2020 (accessed on 14 January 2021). 